INSTITUTO DE PESQUISAS ENERGÉTICAS E NUCLEARES

Autarquia Associada à Universidade de São Paulo

\title{
OXIDAÇÃO DIRETA DO ETILENO GLICOL SOBRE CATALISADORES ELETROQUÍMICOS BINÁRIOS À BASE DE Pt, Pd e Sn SUPORTADOS EM CARBONO PARA APLICAÇÃO EM CÉLULAS ALCALINAS
}

\author{
Leticia Lopes de Souza
}

Dissertação apresentada como parte dos requisitos para obtenção do Grau de Doutorado em Ciências na Área de Tecnologia Nuclear - Materiais.

Orientadora:

Profa. Dra. Christina Aparecida Leão Guedes de Oliveira Forbicini

Coorientador:

Prof. Dr. Almir Oliveira Neto

Versão corrigida

Versão original disponível no IPEN

São Paulo

2016 


\section{DEDICATÓRIA}

Aos meus pais, Ivete e Hermínio, e meu irmão, Eduardo, pelo carinho,apoio e confiança ao longo dessa jornada.

Aos meus amigos que sempre me incentivaram durante a realização deste trabalho, muito obrigada. 


\section{AGRADECIMENTOS ESPECIAIS}

Agradeço:

À Dra. Christina Aparecida Leão Guedes de Oliveira Forbicini e ao Dr. Almir de Oliveira Neto, pela orientação, apoio, compreensão e paciência na orientação deste trabalho. 


\section{AGRADECIMENTOS}

Ao Prof. Dr. Almir Oliveira Neto do Centro de Células a Combustível de Hidrogênio $(\mathrm{CCCH})$ por colocar a disposição o laboratório, pela contribuição no trabalho e pelas valiosas opiniões.

Aos colegas pela troca de conhecimento e pela amizade, em especial ao $\mathrm{Dr}$. Maviael José da Silva, a Dra. Rita Maria Dutra e MSc. Viviane Santos Pereira que me ajudaram constantemente na realização das medidas e no tratamento dos dados.

Aos membros do Seminário de Área pelas sugestões e discussões.

Aos meus amigos Carlos Augusto Pereira de Souza, Shirley Leite dos Reis e Mariane Del Vecchio pelos momentos de alegria e amizade.

Á Capes, pelo apoio financeiro ao projeto.

E a todos que de alguma forma me ajudaram, cada um de sua maneira, sempre com a mesma importância, na realização deste trabalho. 
Cada escolha, por menor que seja, é uma forma de semente que lançamos sobre o canteiro que somos. Um dia, tudo o que agora silenciosamente plantamos, ou deixamos plantar em nós, será plantação que poderá ser vista de longe... 


\section{OXIDAÇÃO DIRETA DO ETILENOGLICOL SOBRE CATALISADORES \\ ELETROQUÍMICOS BINÁRIOS À BASE DE Pt, Pd E Sn SUPORTADOS EM CARBONO PARA APLICAÇÃO EM CÉLULAS ALCALINAS}

Leticia Lopes de Souza

\section{RESUMO}

Os catalisadores eletroquímicos binários de $\mathrm{PtSn} / \mathrm{C}, \mathrm{PdSn} / \mathrm{C}$ e $\mathrm{PtPd} / \mathrm{C}$ foram sintetizados em diferentes proporções pelo método da redução via borohidreto, posteriormente estes foram caracterizados por microscopia eletrônica de transmissão, difração de raios $X$, espectroscopia no infravermelho por transformada de Fourier (PtSn/C e PdSn/C) e energia dispersiva de raios X. As atividades eletroquímicas dos diferentes materiais preparados foram avaliadas por intermédio de voltametria cíclica, cronoamperometria e curvas de polarização em célula a combustível alimentada diretamente por etileno glicol em eletrólito alcalino. As curvas de densidade de potência indicaram que os catalisadores eletroquímicos contendo $\mathrm{Sn}$ e $\mathrm{Pd}$ são mais ativos para a reação de oxidação do etileno glicol, especialmente a composição 70\%:30\% - relação molar entre os metais suportados em carbono - dos catalisadores PtSn/C, PdSn/C e PtPd/C todos superando as medidas de potência do $\mathrm{Pt} / \mathrm{C}$. Este resultado indica que a adição de $\mathrm{Sn}$ e $\mathrm{Pd}$ favorece a oxidação do etileno glicol em meio alcalino. O melhor desempenho observado para os catalisadores eletroquímicos $\mathrm{PtSn} / \mathrm{C}, \mathrm{PdSn} / \mathrm{C}$ e $\mathrm{PtPd} / \mathrm{C}$ (70\%:30\%) poderia estar associado à sua maior seletividade quanto a formação de oxalato, ou seja, a formação deste produto resulta em um maior número de elétrons, por consequência em maiores valores de corrente. 


\title{
DIRECT OXIDATION OF ETHYLENE GLYCOL BY BINARY ELECTROCHEMICAL CATALYSTS BASED ON Pt, Pd AND Sn SUPPORTED ON CARBON SUBSTRATE FOR APPLICATION IN ALKALINE FUEL CELLS
}

\author{
Leticia Lopes de Souza
}

\begin{abstract}
Binary electrochemical catalysts $\mathrm{PtSn} / \mathrm{C}, \mathrm{PdSn} / \mathrm{C}$ and $\mathrm{PtPd} / \mathrm{C}$ were synthesized in different proportions by the method of reduction via borohydride. These were characterized by transmission electron microscopy, X-ray diffraction, Fourier transform infrared spectroscopy (PtSn/C and PdSn/C) and energy dispersive X-ray. The electrochemical activities of the different materials prepared were evaluated by cyclic voltammetry, chronoamperometry and polarization curves for fuel cell powered directly by ethylene glycol in an alkaline electrolyte. Power density curves indicated that the electrochemical catalysts Sn-containing or Pd-containing are more active for ethylene glycol oxidation reaction, particularly the (70\%:30\%) composition of $\mathrm{PtSn} / \mathrm{C}$, $\mathrm{PdSn} / \mathrm{C}$ and $\mathrm{PtPd} / \mathrm{C}$, all of them exceeding power measurements of $\mathrm{Pt} / \mathrm{C}$. These results indicate that the addition of $\mathrm{Sn}$ and $\mathrm{Pd}$ promotes the oxidation of ethylene glycol in an alkaline medium and this improved performance may be associated with a higher selectivity for the formation of oxalate that results in a larger number of electrons, consequently enhancing the current values.
\end{abstract}




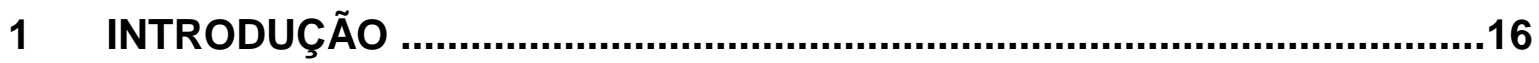

2 OBJETIVO

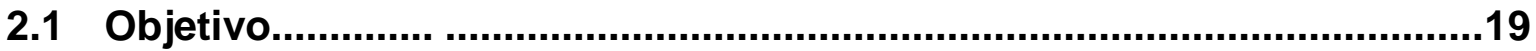

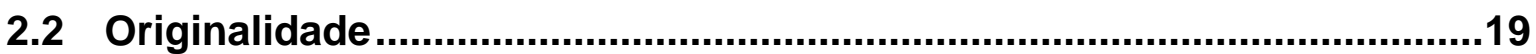

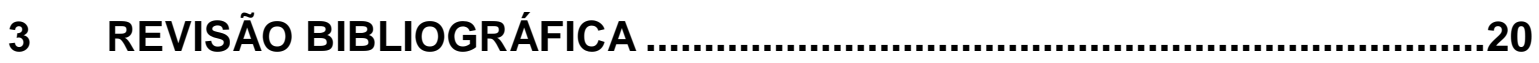

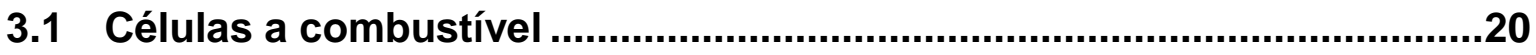

3.2 Célula a Combustível Alcalina a Álcool Direto........................................23

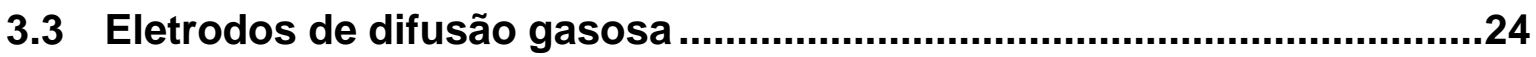

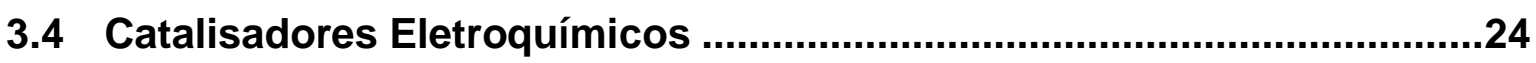

3.4.1 Mecanismo bifuncional e efeito eletrônico …….......................................30

3.5 Células a combustível a álcool direto ......................................................31

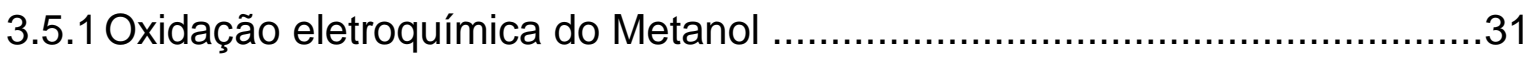

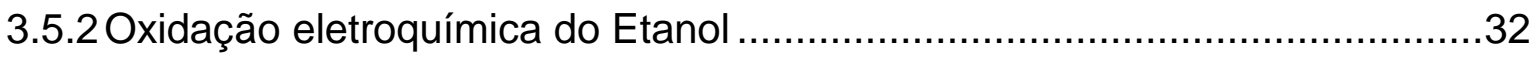

3.5.3 Oxidação eletroquímica do Etileno glicol ....................................................33

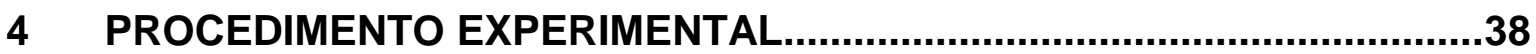

4.1 Síntese dos catalisadores eletroquímicos pelo método borohidreto ....38

4.2 Preparação dos eletrodos de camada fina porosa ...................................41

4.3 Caracterização físico-química dos catalisadores eletroquímicos..........41

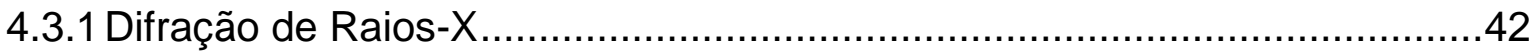

4.3.2 Espectroscopia de energia dispersiva de raios-X (EDX) ….......................43

4.3.3 Microscopia eletrônica de transmissão (MET) ………………………......43

4.3.4 Espectroscopia no infravermelho com transformada de Fourier in situ (FTIR)44

4.4 Caracterização eletroquímica dos catalisadores eletroquímicos ..........45

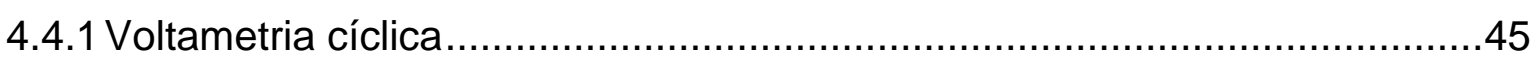

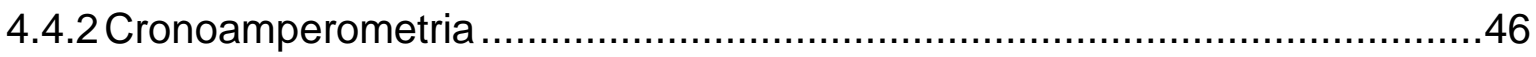

4.5 Testes em célula a combustível unitária .................................................46

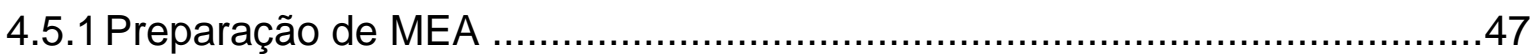

4.6 Tratamento da membrana para utilização em meio alcalino ...................47 


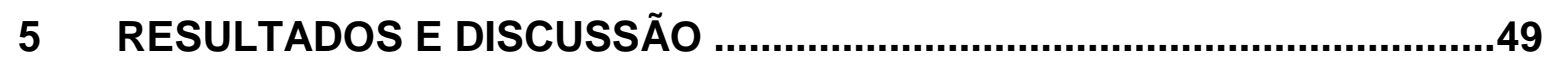

5.1 Caracterização e aplicação dos catalisadores eletroquímicos em AFC 49

5.1.1 Catalisador PtSn/C .......................................................................49

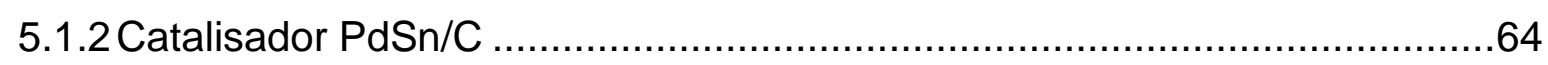

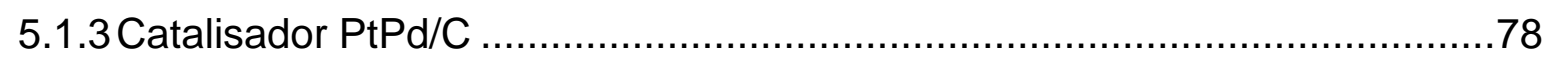

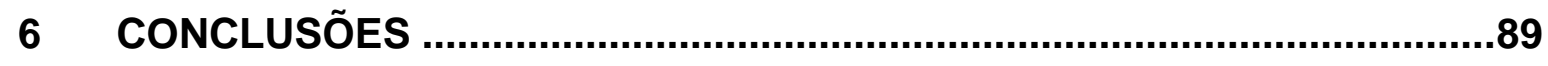

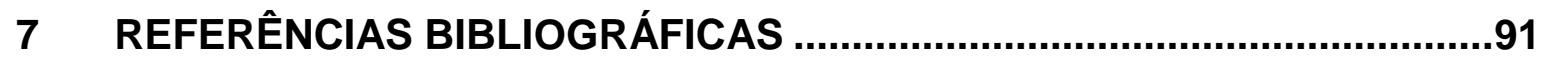




\section{LISTA DE FIGURAS}

Página

FIGURA 1- Os diferentes tipos de Células a Combustível.

.22

FIGURA 2 - Representação esquemática das diferentes vias para oxidação do etileno glicol[50] 34

FIGURA 3 - Método da redução por borohidreto (a) mistura de água+ propanol +metais precursores, (b) adição de carbono e agitação, (c) sonificação da mistura, (d) adição de borohidreto de sódio e (e) agitação por 30 minutos ${ }^{[25]}$ 39

FIGURA 4 - Fluxograma do método de preparação de catalisadores eletroquímicos via redução por borohidreto de sódio ${ }^{[7]}$ 40

FIGURA 5 - Representação do eletrodo rotatório com camada fina porosa [62] 41

FIGURA 6 - Difratogramas dos catalisadores eletroquímicos Pt/C, PtSn/C e do Sn/C suportados em carbono. 50

FIGURA 7 - Micrografias obtidas por microscopia eletrônica de transmissão e distribuição dos tamanhos de partícula dos catalisadores eletroquímicos preparados pelo método do borohidreto: (a) $\mathrm{Pt} / \mathrm{C}$, (b) Sn/C .52

FIGURA 8 - Micrografias obtidas por MET e distribuição dos tamanhos de partícula dos catalisadores eletroquímicos preparados pelo método do borohidreto: a) $\mathrm{PtSn} / \mathrm{C}$ (90:10), b) PtSn/C (70:30) e c)PtSn/C (50:50) .53

FIGURA 9 - Voltametria cíclica de Pt/C e PtSn/C em solução $\mathrm{KOH} 1 \mathrm{~mol} . \mathrm{L}^{-1} \mathrm{com}$ velocidade de varredura de $10 \mathrm{mV} . \mathrm{s}^{-1}$ (ausência de álcool)...... .55

FIGURA 10 - a) Voltamogramas Cíclicos para os catalisadores eletroquímicos de $\mathrm{Pt} / \mathrm{C}$ e $\mathrm{PtSn} / \mathrm{C}$ em solução de $\mathrm{EG} 1 \mathrm{~mol}^{-\mathrm{L}^{-1}}$ e de $\mathrm{KOH} 1 \mathrm{~mol}^{\mathrm{L}} \mathrm{L}^{-1} \mathrm{com}$ velocidade de

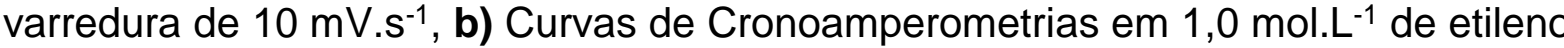
glicol em solução de 1,0 mol.L-1 $\mathrm{KOH}$ para os catalisadores eletroquímicos $\mathrm{PtSn} / \mathrm{C}$ em diferentes composição preparados pelo método de borohidreto no potencial de $0,35 \mathrm{~V}$ (vs. $\mathrm{Ag} / \mathrm{AgCl})$ à $25^{\circ} \mathrm{C}$ 57

FIGURA 11 - Espectros de absorção ATR-FTIR in situ coletados no intervalo de potenciais de $-0,8$ a $0,1 \mathrm{~V}\left(v s\right.$. Ag/AgCl), em solução aquosa de $1 \mathrm{~mol}$. $\mathrm{L}^{-1}$ de etileno glicol e 1,0 mol. $\mathrm{L}^{-1}$ de $\mathrm{KOH}$ para os catalisadores eletroquímicos de $\mathrm{Pt} / \mathrm{C}$ e PtSn/C. Os backgrounds foram coletados em $-0.85 \mathrm{~V}$ (vs. Ag/AgCl), a uma velocidade de varredura de $1 \mathrm{mV} . \mathrm{s}^{-1}$ .59

FIGURA 12 - Intensidade Integrada das bandas do aldeído $\left(1072 \mathrm{~cm}^{-1}\right)$ em função do potencial para os catalisadores eletroquímicos $\mathrm{Pt} / \mathrm{C}, \mathrm{PtSn} / \mathrm{C}$. Os "backgrounds" foram coletados em $-0.85 \mathrm{~V}$ (vs. $\mathrm{Ag} / \mathrm{AgCl}$ ), a uma velocidade de varredura de 1 $\mathrm{mV} . \mathrm{s}^{-1}$ 
FIGURA 13 - Intensidade Integrada das bandas em função do potencial para os catalisadores eletroquímicos $\mathrm{Pt} / \mathrm{C}$ e $\mathrm{PtSn} / \mathrm{C}$ a) oxalato e glicolato, b) estiramento O$\mathrm{H}$ do oxalato.

FIGURA 14 - Intensidade integrada das bandas de $\mathrm{CO}_{2}\left(2343 \mathrm{~cm}^{-1}\right)$ em função do potencial para os catalisadores eletroquímicos de $\mathrm{Pt} / \mathrm{C}$ e $\mathrm{PtSn} / \mathrm{C}$.

FIGURA 15 - Desempenho da célula a combustível em etileno glicol para os eletrocatalisadores $\mathrm{Pt} / \mathrm{C}$ e $\mathrm{PtSn} / \mathrm{C}$ a $100^{\circ} \mathrm{C}$, preparados pelo método do borohidreto, membrana de Nafion 117 tratada com KOH, eletrólito de $\mathrm{EG}+\mathrm{KOH}\left(2 \mathrm{~mol}^{\mathrm{L}} \mathrm{L}^{-1}\right)$, fluxo de $1 \mathrm{~mL} \cdot \mathrm{min}^{-1}$ 63

FIGURA 16 - a) Difratogramas dos catalisadores eletroquímicos $\mathrm{Pd} / \mathrm{C}, \mathrm{PdSn} / \mathrm{C}$ e do $\mathrm{Sn} / \mathrm{C}$ suportados em carbono b) Refinamento Pawley para o plano cristalino (220).

FIGURA 17 - Micrografias obtidas por microscopia eletrônica de transmissão e distribuição dos tamanhos de partícula dos catalisadores eletroquímicos preparados pelo método do borohidreto: (a) $\mathrm{Pd} / \mathrm{C}$, (b) Sn/C. 67

FIGURA 18 - Micrografias obtidas por microscopia eletrônica de transmissão e distribuição dos tamanhos de partícula dos catalisadores eletroquímicos preparados pelo método do borohidreto: (a) PdSn/C (90:10), (b) PdSn/C (70:30) e (c) PdSn/C (50:50). 68

FIGURA 19- Voltametria cíclica de $\mathrm{Pd} / \mathrm{C}$ e $\mathrm{PdSn} / \mathrm{C}$ em solução de $\mathrm{KOH} 1 \mathrm{~mol} . \mathrm{L}^{-1}$ com velocidade de varredura de $10 \mathrm{mV} \mathrm{s}^{-1}$

FIGURA 20 - a) Voltametria de varredura linear anódica para os catalisadores eletroquímicos de $\mathrm{Pd} / \mathrm{C}$ e $\mathrm{PdSn} / \mathrm{C}$ em solução de EG $1 \mathrm{~mol} . \mathrm{L}^{-1}$ em $\mathrm{KOH} 1 \mathrm{~mol} . \mathrm{L}^{-1}$ com velocidade de varredura de $10 \mathrm{mV} \mathrm{s}^{-1}$, b) Curvas cronoamperométricas em $\mathrm{EG}$ 1 mol.L-1 em KOH 1 mol.L-1 para os catalisadores eletroquímicos $\mathrm{Pd} / \mathrm{C}$ e $\mathrm{PdSn} / \mathrm{C}$ em diferentes composições, preparados pelo método de borohidreto, no potencial de $-0,35 \mathrm{~V}$ (vs. Ag/AgCl) a $25^{\circ} \mathrm{C}$

FIGURA 21 - Espectros de absorção ATR-FTIR in situ coletados no intervalo de potenciais de $-0,8$ a $0,1 \mathrm{~V}$ (vs $\mathrm{Ag} / \mathrm{AgCl}$ ), em solução aquosa de $\mathrm{EG} 1 \mathrm{~mol} . \mathrm{L}^{-1} \mathrm{em}$ $\mathrm{KOH} 1 \mathrm{~mol} . \mathrm{L}^{-1}$ para os catalisadores eletroquímicos de $\mathrm{Pd} / \mathrm{C}$ e $\mathrm{PdSn} / \mathrm{C}$. Os backgrounds foram coletados em -0.85 V (vs $\mathrm{Ag} / \mathrm{AgCl}$ ), a uma velocidade de varredura de $1 \mathrm{mV} \mathrm{s}^{-1}$ 74

FIGURA 22 - Intensidade Integrada das bandas do aldeído $\left(1072 \mathrm{~cm}^{-1}\right)$ em função do potencial para os catalisadores eletroquímicos $\mathrm{Pd} / \mathrm{C}, \mathrm{PdSn} / \mathrm{C}$. Os backgrounds foram coletados em $-0.85 \mathrm{~V}$ ( $v s$. $\mathrm{Ag} / \mathrm{AgCl}$ ), a uma velocidade de varredura de $1,0 \mathrm{mV} \mathrm{s}^{-1}$

FIGURA 23 - Intensidade Integrada das bandas em função do potencial para os catalisadores eletroquímicos $\mathrm{Pd} / \mathrm{C}$ e $\mathrm{PdSn} / \mathrm{C}$ (a) oxalato e glicolato, (b) estiramento $\mathrm{O}-\mathrm{H}$ do oxalato 
FIGURA 24 - Intensidade integrada das bandas de $\mathrm{CO}_{2}\left(2343 \mathrm{~cm}^{-1}\right)$ em função do potencial para os catalisadores eletroquímicos de $\mathrm{Pd} / \mathrm{C}$ e $\mathrm{PdSn} / \mathrm{C}$.

FIGURA 25 - Desempenho da célula a combustível em etileno glicol para os catalisadores eletroquímicos $\mathrm{Pd} / \mathrm{C}$ e $\mathrm{PdSn} / \mathrm{C}$ a $100^{\circ} \mathrm{C}$, preparados pelo método do borohidreto, membrana de Nafion 117 tratada com KOH, eletrólito de $\mathrm{EG}+\mathrm{KOH}$ (2mol.L-1), fluxo de $1 \mathrm{~mL} \cdot \mathrm{min}^{-1}$ .78

FIGURA 26 - Difratogramas dos catalisadores eletroquímicos Pt/C, $\mathrm{Pd} / \mathrm{C}$ e do $\mathrm{PtPd} / \mathrm{C}$ suportados em carbono. 79

FIGURA 27 - Micrografias obtidas por microscopia eletrônica de transmissão e distribuição dos tamanhos de partícula dos catalisadores eletroquímicos preparados pelo método do borohidreto: (a) PtPd/C (90:10), (b) PtPd/C (70:30) e (c) PtPd/C (50:50)

FIGURA 28- Voltametria cíclica de Pt/C, Pd/C e PtPd/C (90:10); (70:30); (50:50), em solução de $\mathrm{KOH} 1,0 \mathrm{~mol} . \mathrm{L}^{-1} \mathrm{com}$ velocidade de varredura de $10 \mathrm{mV} . \mathrm{s}^{-1}$ .83

FIGURA 29 - (a) Voltamogramas cíclicos para os catalisadores eletroquímicos de $\mathrm{Pt} / \mathrm{C}, \mathrm{Pd} / \mathrm{C}$ e $\mathrm{PtPd} / \mathrm{C}$ em solução de $\mathrm{EG} 1 \mathrm{~mol} . \mathrm{L}^{-1}$ e $\mathrm{KOH} 1 \mathrm{~mol} . \mathrm{L}^{-1} \mathrm{com}$ velocidade de varredura de $10 \mathrm{mV} . \mathrm{s}^{-1}$; (b) Curvas de cronoamperometrias em EG 1 mol.L-1 e $\mathrm{KOH} 1,0 \mathrm{~mol} . \mathrm{L}^{-1}$ para os catalisadores eletroquímicos PtPd/C em diferentes composições preparados pelo método de borohidreto no potencial de $-0,35 \mathrm{~V}$ (vs. $\mathrm{Ag} / \mathrm{AgCl})$ à $25^{\circ} \mathrm{C}$. 86

FIGURA 30 - Desempenho da célula a combustível em etileno glicol para os catalisadores eletroquímicos $\mathrm{Pt} / \mathrm{C}, \mathrm{Pd} / \mathrm{C}$ e $\mathrm{PtPd} / \mathrm{C}$ a $100^{\circ} \mathrm{C}$, preparados pelo método do borohidreto, membrana de Nafion 117 tratada com KOH, eletrólito de $\mathrm{EG}+\mathrm{KOH}$ (2mol.L-1), fluxo de $1 \mathrm{~mL} \cdot \mathrm{min}^{-1}$ 


\section{LISTA DE TABELAS}

Página

TABELA 1 - Características principais dos diferentes tipos de células a

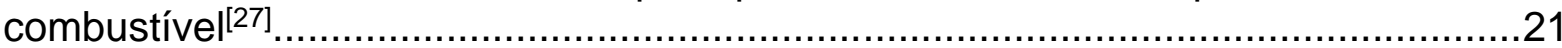

TABELA 2 - Valores de entalpia e energia livre padrões para a reação de combustão dos alcoóis e potencial padrão do eletrodo............................................33

TABELA 3 - Tamanho médio de cristalito, parâmetro de rede e composição em $\% \mathrm{~mol}$ por EDX para catalisadores eletroquímicos à base $\mathrm{Pt}$ e $\mathrm{Sn}$ sobre substrato de carbono..........................................................................

TABELA 4 - Tamanho médio de cristalito, parâmetro de rede e composição em $\% \mathrm{~mol}$ por EDX para catalisadores eletroquímicos à base $\mathrm{Pd}$ e $\mathrm{Sn}$

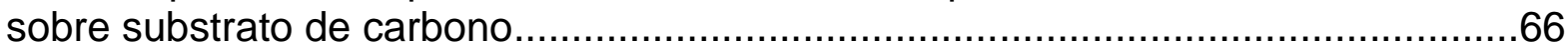

TABELA 5 - Tamanho médio de cristalito, parâmetro de rede e composição em $\% \mathrm{~mol}$ por EDX para catalisadores eletroquímicos à base $\mathrm{Pt}$ e $\mathrm{Pd}$ sobre substrato de carbono. .80

TABELA 6 - Composição dos catalisadores binários e suas densidades de potência determinadas na operação de uma célula a combustível alcalina unitária 


\section{GLOSSÁRIO DE SÍMBOLOS E ABREVIATURAS}

CaC - Células a Combustível

AFC - Célula a Combustível Alcalina (Alkaline Fuel Cell)

PAFC - Célula a Combustível de ácido fosfórico (Phosphoric acid fuel cells)

PEMFC -Célula a Combustível de membrana de troca protônica (Proton exchange fuel cells)

MCFC - Célula a Combustível de carbonato fundido (Molten carbonate fuel cells)

SOFC - Célula a Combustível de óxidos sólidos (Solid oxide fuel cells)

DAFC - Célula a combustível de álcool direto (Direct alcohol fuel cells)

DMFC - Célula a combustível de metanol direto (Direct methanol fuel cells)

DEFC - Célula a combustível de etanol direto (Direct ethanol fuel cells)

FTIRS - Espectroscopia de Infravermelho por Transformada de Fourier (Fourier transform infrared spectroscopy)

ATR - Refletância total atenuada (Attenuated Total Reflectance)

DRX - Difração de Raios-X (X-ray diffraction)

EDX - Espectroscopia de energia dispersiva de raios-X

MET - Microscopia Eletrônica de Transmissão (Transmission electron microscopy)

VC - Voltametria Cíclica

$\mathrm{CA}$ - Cronoamperometria

$E G$ - Etileno glicol

EDG - Eletrodos de Difusão Gasosa

EQM - Eletrodos Quimicamente Modificados

ERH - Eletrodo reversível de hidrogênio 
PROX-CO - Reação de Oxidação Preferencial do Monóxido de Carbono

RRO - Reação de redução do oxigênio

$\mathrm{ROH}$ - Reação de oxidação do hidrogênio

OCV - Potencial de Circuito Aberto (Open Circuit Voltage)

MEA - Conjunto eletrodo-membrana-eletrodo (Membrane Electrode Assembly)

DEMS - Espectrometria de massa eletroquímica diferencial

ECTDMS - Espectroscopia de massa de dessorção térmica eletroquímica

AEM - Membrana trocadora de ânion (Anion exchange membrane)

GDL - Camada Difusora (Gas Diffusion Layer)

CFC - Cúbica de Face Centrada

PTFE - Politetrafluoretileno

$\eta$ - Rendimento 


\section{INTRODUÇÃO}

As células a combustível são dispositivos que convertem a energia química de um combustível (hidrogênio, metanol, etanol, etileno glicol etc.) e um oxidante $\left(\mathrm{O}_{2}\right)$ em energia elétrica e calor ${ }^{[1-2]}$. Dentre os principais tipos de células a combustível, as células AFC (células a combustível alcalinas) apresentam características versáteis, que tornam seu uso viável tanto para geração estacionária de energia elétrica, aplicações portáteis e aplicações móveis ${ }^{[1-3]}$.

As células a combustível alcalinas (AFC- Alkaline Fuel Cells) utilizam como eletrólito uma solução de hidróxido de potássio $(\mathrm{KOH})$ e a sua operação ocorre em uma faixa de temperatura de 40-120 ${ }^{\circ} \mathrm{C}$. Este tipo de célula apresenta desempenho do cátodo melhor em relação as células que operam em meio ácido já que a redução do oxigênio é cinéticamente favorecida neste meio reacional, e podem também utilizar materiais não nobres para confecção dos catalisadores ${ }^{[3-7]}$.

Os catalisadores binários também apresentam ampla utilidade nas mais diferentes áreas de aplicação tecnológica, o que Ihes confere uma importância considerável. No entanto, apesar dos avanços científicos e técnicos, a preparação de catalisadores eletroquímicos cada vez mais eficazes ainda é necessária, sendo as combinações entre diferentes metais de extrema relevância para o desenvolvimento ${ }^{[8-9]}$.

Outro problema está relacionado ao emprego de catalisadores eletroquímicos que utilizam platina em excesso, o que pode resultar em produtos com alto custo e também na escassez deste metal, visto que o fornecimento de platina é limitado devido à sua baixa abundância na natureza ${ }^{[10-12]}$.

Dentre as possíveis alternativas ao uso da platina está o emprego do paládio na preparação do catalisador eletroquímico ${ }^{[13-15]}$. A vantagem no uso do paládio pode ser atribuída a sua maior disponibilidade na crosta terrestre, já que o paládio é pelo menos cinquenta vezes mais abundante do que a platina ${ }^{[16]}$. Além disso, diferentemente dos catalisadores de platina, o paládio mostra maior tolerância aos intermediários contendo $\mathrm{CO}^{[17]}$. O paládio também tem apresentado uma maior 
atividade eletrocatalítica em relação a Pt/C quando empregado nos estudos em células alcalinas. ${ }^{[16,18]}$.

Neste contexto, as avaliações de catalisadores eletroquímicos binários à base de platina, paládio e estanho, para aplicações em células a combustível, ganham uma importância peculiar por representar um importante campo a ser investigado em trabalhos envolvendo geração de energia. Neste trabalho, foram realizadas análises de Microscopia Eletrônica de Transmissão (MET), Difração de Raios X (DRX), Infravermelho (FTIR) e Energia Dispersiva de Raios X (EDX) para a caracterização dos catalisadores eletroquímicos, enquanto que Voltametria Cíclica (VC), Cronoamperometria (CA) e Testes em célula a combustível foram utilizadas para avaliar as atividades eletrocatalíticas dos catalisadores binários nas reações de oxidação eletroquímica do etileno glicol (EG) em meio básico. É importante salientar que a técnica de Infravermelho (FTIR) permite correlacionar a atividade dos diferentes materiais preparados com as vias de produção na reação de oxidação do EG, consequentemente auxilia na determinação da rota de reação, além de avaliar se esta ocorre de modo completo ou incompleto.

Em um sistema de célula a combustível suprido com hidrogênio há uma enorme preocupação e severas exigências de medidas de segurança devido às dificuldades de armazenamento e manuseio deste combustível. Uma alternativa a este problema seria que o hidrogênio utilizado na célula fosse produzido on-board através da reforma do gás natural[19]. Portanto, nos últimos anos, as células a combustível que utilizam alcoóis diretamente como combustíveis (DAFC - Direct Alcohol Fuel Cell) vêm despertando interesse, pois, apresentam como principal vantagem a não estocagem do hidrogênio e a possibilidade de gerá-lo através da reforma de álcoo|[20]. No entanto, o processo de reforma, além de hidrogênio produz também CO, que se adsorve fortemente sobre a superfície do catalisador convencional de $\mathrm{Pt} / \mathrm{C}$ (nanopartículas de platina ancoradas em carbono), afetando drasticamente o desempenho da célula, mesmo quando traços deste contaminante estão presentes ${ }^{[5,19]}$. Desta forma, a tolerância a monóxido de carbono é um fator importante na escolha de um catalisador eletroquímico para oxidação anódica de hidrogênio em células a combustível alimentadas com gás reformado ${ }^{[5,19]}$. 
Algumas abordagens têm sido empregadas na tentativa de solucionar o problema de contaminação do eletrodo por CO. Uma destas propostas está relacionada a produção de catalisadores binários, ou seja, a presença de um segundo metal além da $\mathrm{Pt}$, como $\mathrm{Ru}, \mathrm{Sn}$, Mo e Os, formando ligas (solução sólida substitucional completa ou incompleta e/ou solução sólida intersticial) ou codepósitos dispersos em carbono, resultando em um incremento significativo na tolerância ao $\mathrm{CO}^{[19]}$.

Logo, o propósito desta pesquisa é avaliar as atividades eletrocatalíticas dos catalisadores binários $\mathrm{PtSn} / \mathrm{C}, \mathrm{PdSn} / \mathrm{C}, \mathrm{PtPd} / \mathrm{C}$ nas reações de oxidação eletroquímica do EG em meio básico. 


\section{OBJETIVO}

\subsection{Objetivo}

O presente trabalho tem por objetivo verificar a eficiência dos catalisadores eletroquímicos binários de PtSn, PdSn e PtPd suportados em carbono para a oxidação direta do etileno glicol e sua aplicação em células a combustível alcalinas (AFC).

\subsection{Originalidade}

Levando em consideração os estudos presentes na literatura [21-25] seria interessante verificar a oxidação do etileno glicol em meio alcalino utilizando voltametria e espectroscopia de infravermelho e determinar os possíveis produtos formados para a oxidação:

1) A via preferencial daria como produto final $\mathrm{o} \mathrm{CO}_{2}$;

2) Ou a via paralela podendo formar: glicoaldeído, glioxal, ácido glicólico, ácido glioxílico, ácido oxálico;

O trabalho também pretende verificar se as curvas de densidade de potência são mais ativas para a reação de oxidação do etileno glicol para os catalisadores eletroquímicos binários de PtSn, PdSn e PtPd em relação ao catalisador Pt/C. 


\section{REVISÃO BIBLIOGRÁFICA}

\subsection{Células a combustível}

A célula a combustível foi inventada há mais de 150 anos, mais precisamente em 1839, pelo advogado e cientista Willian Robert Grove. Seu invento consistia de uma célula alimentada com $\mathrm{H}_{2} \mathrm{e} \mathrm{O}_{2}$, utilizando ácido sulfúrico diluído como eletrólito. Grove nomeou seu invento de gas battery (bateria a gás), sendo o termo fuel cell ou célula a combustível introduzido 50 anos depois pelos químicos Ludwig Mond e Charles Langer ${ }^{[26]}$.

Em 1973, após uma grave crise energética mundial, as pesquisas sobre células a combustível $(\mathrm{CaC})$ cresceram e ganharam força, principalmente em países onde a energia é oriunda de termoelétricas, altamente dependentes de derivados de petróleo para produção de energia elétrica[26]. No entanto, as $\mathrm{CaC}$ só começaram a ter aplicação prática na década de 80 , no programa espacial norte-americano, mesmo a custos muito elevados. Com o grande desenvolvimento na área de materiais dos últimos 20 anos as $\mathrm{CaC}$ tornaram-se uma das alternativas mais promissoras para aplicação como fonte elétrica em sistemas estacionários, portáteis e móveis (veículos). Estes dispositivos são capazes de converter energia química armazenada nos reagentes em energia elétrica e calor, através de um par de eletrodos quimicamente modificados (EQM) acoplados (anódico e catódico), de maneira eficiente e com baixa emissão de poluentes.

No atual estágio de desenvolvimento há vários tipos de $\mathrm{CaC}$, classificadas de acordo com o eletrólito utilizado, com a temperatura de operação e que se prestam a diferentes tipos de aplicações sendo apresentadas através da TAB. 1: 
TABELA 1 - Características principais dos diferentes tipos de células a combustível.[27]

\begin{tabular}{|c|c|c|c|c|c|}
\hline Tipo' & $\begin{array}{c}\text { Rendimento } \\
\eta \\
(\%)\end{array}$ & 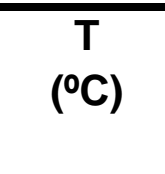 & $\begin{array}{l}\text { Potência } \\
\text { (kW) }\end{array}$ & Eletrólito & Aplicação \\
\hline$\overline{A F C}$ & 50 & $40-120$ & $10-100$ & $\begin{array}{l}\text { Alcalino: } \\
\text { Solução de } \\
\mathrm{KOH}\end{array}$ & $\begin{array}{c}\text { Naves } \\
\text { espaciais e } \\
\text { estacionárias }\end{array}$ \\
\hline PEMFC & 45 & $80-120$ & $1-1000$ & $\begin{array}{c}\text { Polímero Ácido } \\
\text { Fluorosulfonato } \\
\text { tipo Nafion } \\
\text { (sólido) }\end{array}$ & $\begin{array}{c}\text { Transporte } \\
\text { Portátil } \\
\text { Estacionária }\end{array}$ \\
\hline PAFC & 45 & 200 & $100-5000$ & $\begin{array}{c}\text { Ácido Fosfórico } \\
\qquad \mathrm{H}_{3} \mathrm{PO}_{4}\end{array}$ & $\begin{array}{c}\text { Geração } \\
\text { Estacionária }\end{array}$ \\
\hline MCFC & 50 & 650 & $100-10.000$ & $\begin{array}{c}\text { Carbonato } \\
\text { fundido de K ou } \\
\mathrm{Na} \text { (líquido) }\end{array}$ & $\begin{array}{c}\text { Geração } \\
\text { Estacionária }\end{array}$ \\
\hline SOFC & 50 & $\begin{array}{l}800- \\
1000\end{array}$ & $\begin{array}{c}1000- \\
100.000\end{array}$ & $\begin{array}{l}\text { Óxido Metálico } \\
\text { Sólido, } \\
\text { tipicamente } \\
\text { zircônia } \\
\text { estabilizada } \\
\text { YSZ (sólido) }\end{array}$ & $\begin{array}{c}\text { Geração } \\
\text { Estacionária }\end{array}$ \\
\hline
\end{tabular}

(1) AFC - alcalina, PEMFC- membrana de troca protônica como eletrólito (normalmente o Nafion ${ }^{\circledR}$ ), PAFC- de ácido fosfórico, MCFC- de carbonato fundido e SOFC- de óxidos sólidos.

Na TAB. 1 estão apresentadas as principais características das células a combustíveis. A grande vantagem destas tecnologias é a baixa emissão de poluentes associada a uma alta eficiência. Este aspecto pode garantir à $\mathrm{CaC}$ um lugar de destaque num planejamento econômico/ecológico da matriz energética nacional. Entretanto, estes dispositivos possuem desvantagens no caso de células que operam com o gás hidrogênio, há obstáculos relacionados à produção, 
armazenamento e distribuição deste combustível[27], portanto, o estudo e desenvolvimento de $\mathrm{CaC}$ associam outras áreas de conhecimento, como, por exemplo, a produção de hidrogênio (combustível da $\mathrm{CaC}$ ) a partir da reforma de outros combustíveis (fósseis, de biomassa), incluindo-se o etanol, estratégico para o Brasil e o etileno glicol $\left(\mathrm{C}_{2} \mathrm{H}_{6} \mathrm{O}_{2}\right)$ que apresenta uma alta conversão a $\mathrm{CO}_{2}$.

Na FIG.1 é mostrado o esquema de operação de diferentes tipos de células a combustíveis.

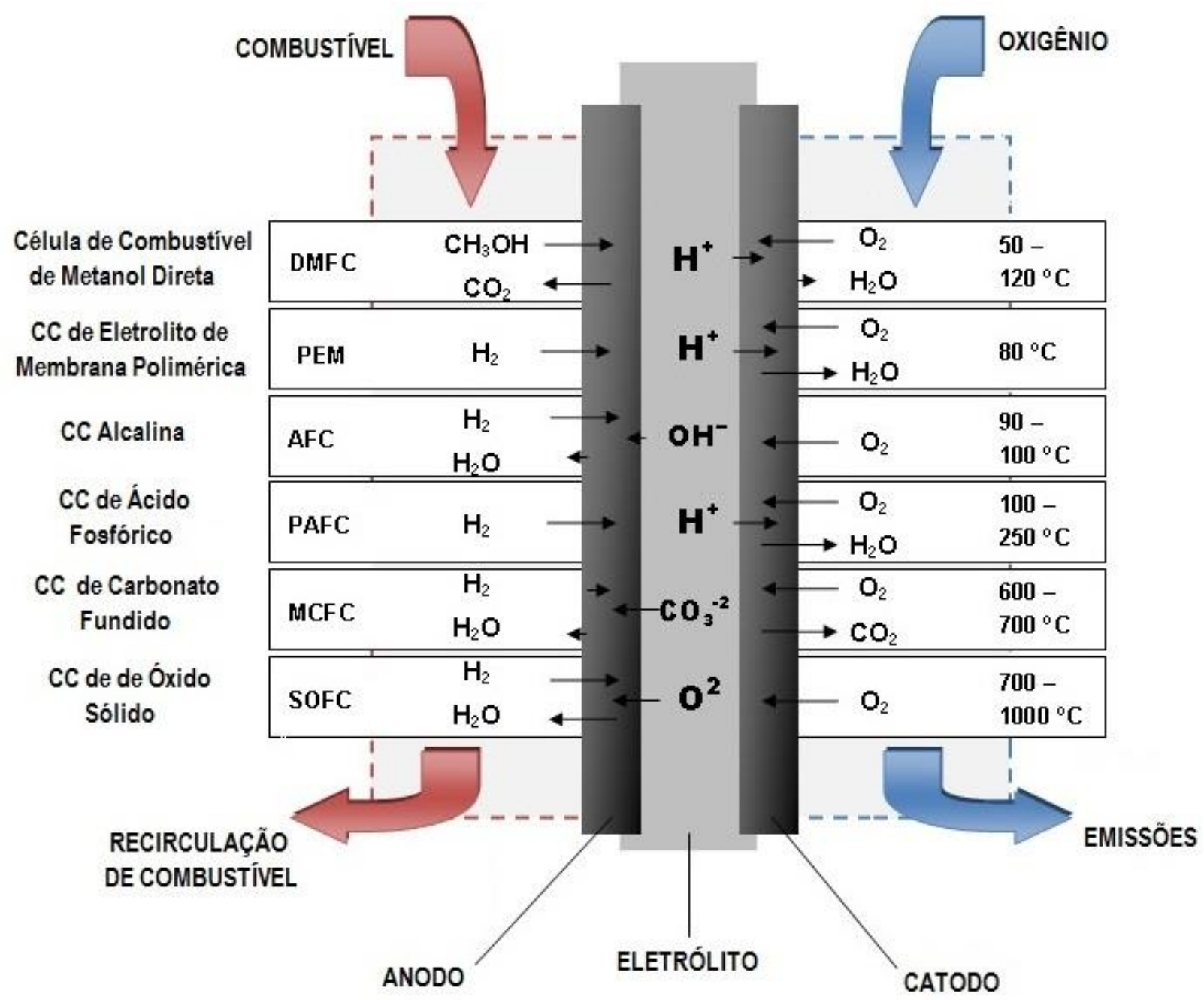

FIGURA 1 - Os diferentes tipos de Células a Combustíveis.

Através da FIG. 1 é possível notar que o funcionamento de uma célula a combustível ocorre a partir da alimentação externa e contínua de um combustível $\left(\mathrm{H}_{2}\right.$, metanol, etanol ou $\left.\mathrm{EG}\right)$ e um oxidante $\left(\mathrm{O}_{2}\right.$ ou ar). No ânodo ocorre a reação de 
oxidação do combustível a prótons $\left(\mathrm{H}^{+}\right)$e elétrons (e). Os elétrons são transportados por um circuito externo em direção ao cátodo e os prótons são transportados até o cátodo através do eletrólito. No cátodo ocorre a reação de redução do oxigênio, com o envolvimento dos prótons e elétrons provenientes do ânodo, gerando água e calor. Ambas as reações, oxidação do hidrogênio $(\mathrm{ROH})$ e redução do oxigênio (RRO), ocorrem na interface eletrodo/eletrólito, cuja reação eletroquímica global de formação de água apresenta potencial reversível de 1,23 $\mathrm{V}$ vs. $\mathrm{ERH}$, a $25^{\circ} \mathrm{C}^{[25]}$. Abaixo encontram-se as reações que ocorrem em uma célula a combustível $(\mathrm{CaC})$ operando apenas com hidrogênio e oxigênio, representadas pelas Eq.1-3:

Ânodo: $\mathrm{H}_{2}+2 \mathrm{H}_{2} \mathrm{O} \rightarrow 2 \mathrm{H}_{3} \mathrm{O}^{+}+2 e^{-}$ Eq.1

Cátodo: $2 e^{-}+2 \mathrm{H}_{3} \mathrm{O}^{+}+1 / 2 \mathrm{O}_{2} \rightarrow 3 \mathrm{H}_{2} \mathrm{O}$ Eq.2

Reação Global: $\mathrm{H}_{2}+1 / 2 \mathrm{O}_{2} \rightarrow \mathrm{H}_{2} \mathrm{O}$

Desde os anos 60, o grande objetivo das pesquisas de $\mathrm{CaC}$ é aumentar a sua potência e diminuir a carga de metais nobres nos catalisadores eletroquímicos para reduzir os custos.

A platina e os metais do grupo da platina são os materiais catalisadores mais utilizados sobre suportes inertes, como o carbono, para as reações eletroquímicas nas $\mathrm{CaC}$ que operam com eletrólitos ácidos ou alcalinos. Tentativas têm sido feitas para obter catalisadores de elevada área superficial de modo a alcançar altas eficiências com baixo carregamento de catalisador.

\subsection{Célula a Combustível Alcalina a Álcool Direto}

As células ADAFCs (células a combustíveis de ácool direto em meio alcalino) apresentam algumas vantagens sobre uma célula PEMFC convencional (meio ácido), por exemplo, o aumento da reação cinética de redução do oxigênio, uma 
energia de ativação inferior da reação de oxidação do álcool, menor contaminação do eletrodo por $\mathrm{CO}$, a possibilidade de utilizar metais menos nobres do que $\mathrm{Pt}$, os componentes da célula praticamente não sofrem corrosão, entre outros ${ }^{[19,28]}$.

\subsection{Eletrodos de difusão gasosa}

Os eletrodos de difusão gasosa (EDG) apresentam elevada área superficial onde ocorre a difusão na fase gasosa dos reagentes para alcançar o sítio eletrocatalítico[20]. O desenvolvimento desses eletrodos, em particular na região onde ocorre as reações de RRO no cátodo, é de extremo interesse devido à baixa solubilidade dos gases reagentes indispensável para o bom funcionamento das $\mathrm{CaC}$.

O eletrodo de difusão gasosa que merece destaque é os eletrodos hidrofóbicos de carbono com platina pura ou em ligas. Estes eletrodos têm apresentado maior eficiência para aplicação em células a combustível com eletrólitos aquosos ácidos, alcalinos e com eletrólitos de membrana polimérica. Neste último caso, uma limitação para o uso destes eletrodos era a elevada carga de platina requerida para obter desempenho satisfatório. Entretanto, no final da década de 80 foi demonstrado que estas células podem operar com eletrodos contendo baixas cargas de catalisador, em níveis de $0,2 \mathrm{mg}_{\mathrm{pt}} \cdot \mathrm{cm}^{-2}[29]$. Este fato aumentou o interesse nesta tecnologia e, atualmente, mais de uma centena de grupos tem realizado pesquisas neste sistema.

\subsection{Catalisadores Eletroquímicos}

A platina (Pt) é o catalisador eletroquímico mais amplamente usado nas $\mathrm{CaC}$, tanto no ânodo como no cátodo, mas seu recursos naturais limitados comprometem a comercialização das $\mathrm{CaC}$. Esforços recentes na pesquisa por materiais que substituam a $\mathrm{Pt}$, total ou parcialmente, descobriram nos catalisadores eletroquímicos à base de paládio uma oportunidade de reverter o problema. 
Grigoriev et al. ${ }^{[28]}$ em seus trabalhos verificaram que o paládio é muito comum na crosta da Terra, no entanto estava sendo pouco estudado para aplicações em células tipo PEM apesar de suas interessantes propriedades eletrocatalíticas. Observaram também que uma maneira de reduzir o custo das $\mathrm{CaC}$ é diminuir a carga de Pt partindo para o desenvolvimento de catalisadores mistos com teor de $\mathrm{Pt}$ reduzida, principalmente catalisadores de $\mathrm{PtRu}$ e PtSn. O método de adsorção/redução simultânea foi aplicado nos catalisadores à base de $\mathrm{Pt}$ e Pd. Estes catalisadores foram caracterizados utilizando o método de voltametria cíclica e notou-se que os catalisadores à base de Pd apresentaram diminuição da superfície eletroquimicamente ativa em comparação com os eletrodos a base de Pt. Os catalisadores desenvolvidos também foram utilizados para a fabricação de MEAs com carga de metal de $3,5 \times 10^{-1} \mathrm{mg} \cdot \mathrm{cm}^{-2}$ no cátodo e no ânodo. No ânodo aplicaramse catalisadores à base de $\mathrm{Pd}$ e/ou Pt e no cátodo apenas catalisadores à base de Pt. Os testes dos MEAs foram realizados em uma célula a combustível de $25 \mathrm{~cm}^{2}$ com os gases $\mathrm{H}_{2} / \mathrm{O}_{2}$ e demonstraram uma performance elétrica de $1 \mathrm{~W} . \mathrm{cm}^{-2}$ em condições ideais de operação. Em geral, o desempenho elétrico das células que apresentam catalisadores no ânodo à base de Pd foi menor do que o de Pt. No entanto, os resultados obtidos pelo método de adsorção/redução simultâneos mostraram um caminho promissor para a preparação destes catalisadores eletroquímicos demonstrando a possibilidade de substituição da Pt por Pd.

Posteriormente, Ticianelli et al. ${ }^{[20]}$ realizaram trabalhos com a presença de um segundo elemento além da platina $(\mathrm{Pt})$, como molibdênio $(\mathrm{Mo})$, cobre $(\mathrm{Cu})$, ferro $(\mathrm{Fe})$ e tungstênio (W), formando ligas ou co-depósitos dispersos em carbono. O mecanismo intrínseco postula que a presença do segundo metal modifica a energia de quimissorção de $\mathrm{H}_{2}$ e $\mathrm{CO}$ por um mecanismo de doação/retrodoação de elétrons que enfraquecem a ligação Pt-CO. Outra abordagem empregada para reduzir os efeitos do envenenamento por $\mathrm{CO}$ consiste na aplicação de pulsos de corrente na célula durante a operação na presença de CO. Como conseqüência do pulso, o material anódico é forçado a operar transientemente em valores mais positivos de potencial, suficientes para proceder à oxidação eletroquímica de $\mathrm{CO}$ a $\mathrm{CO}_{2}$. Observaram também, que a tolerância ao CO para os eletrodos confeccionados a partir das camadas difusoras baseadas em Mo/C e W/C dá-se pela ocorrência paralela de uma etapa eletroquímica e uma etapa química de conversão de $\mathrm{CO}$ a 
$\mathrm{CO}_{2}$. O mesmo não é valido para os materiais à base de $\mathrm{Fe}$ e $\mathrm{Cu}$, que na temperatura de operação da célula PEM não favorecem a ocorrência de qualquer reação química ou eletroquímica de oxidação de $\mathrm{CO}$.

Kadirgan et. al. ${ }^{[30]}$ verificaram que células do tipo PEM requerem uma alimentação com hidrogênio com teor de $\mathrm{CO}$ abaixo de $5 \mathrm{ppm}$. Este hidrogênio normalmente é produzido por meio de reforma a vapor ou oxidação parcial do gás natural. $\mathrm{O}$ envenenamento dos catalisadores de Pt por $\mathrm{CO}$ diminui significativamente a eficiência energética das $\mathrm{CaCs}$. Mostraram também que há duas possibilidades de eliminar ou diminuir o efeito do envenenamento por $\mathrm{CO}$. O primeiro é o aumento da temperatura de trabalho das células para $200^{\circ} \mathrm{C}$, elevando a tolerância dos catalisadores eletroquímicos de Pt para 20.000 - 30.000 ppm de CO. A segunda maneira é com base no desenvolvimento de novos catalisadores anódicos tolerantes a $\mathrm{CO}$ e propuseram o estudo das ligas bimetálicas de Pt-Pd e Pt-Co como materiais para eletrodo em $\mathrm{CaC}$, especialmente para a oxidação eletroquímica do $\mathrm{CO}$. Observaram, após caracterização, uma melhora na tolerância de CO para o catalisador eletroquímico Pt-Pd em comparação com o Pt/C. Com base nos resultados obtidos, concluíram que a inibição dos efeitos de envenenamento poderia ser atribuída a incapacidade do $\mathrm{CO}$ em ocupar os lugares vagos obtidos pela adsorção do hidrogênio e as eventuais oxidação sobre o catalisador bimetálico. Além disso, o Pd pode atuar como um fornecedor de átomos de hidrogênio, disponibilizando locais adjacentes para as moléculas de hidrogênio se dissociarem. O catalisador eletroquímico $\mathrm{Pt}-\mathrm{Co} / \mathrm{C}$ preparado por redução com dietileno glicol foi visto como promissor para células tipo PEM. Embora seja muito difícil separar a estrutura, os efeitos eletrônicos e a distribuição de $\mathrm{CO}$ em ligas de Pt-Co, é razoável propor que os efeitos eletrônicos podem desempenhar o papel principal na adsorção energética $\mathrm{Pt}-\mathrm{OH}$, assim como na reatividade dos átomos na superfície da platina. Ao compararem as curvas de polarização com eletrodos convencionais notaram uma resistência ôhmica ligeiramente superior. Porém estes catalisadores apresentam menor custo em relação aos catalisadores comerciais, a estabilidade dos eletrodos de $\mathrm{Pt}-\mathrm{Co} / \mathrm{C}$ é limitada, particularmente em temperaturas acima de $60^{\circ} \mathrm{C}$, e, portanto, a aplicação se restringe a células de combustível de baixa temperatura. 
Ferreira ${ }^{[31]}$ realizou estudos de catalisadores binários e ternários à base de $\mathrm{Pt}$, Sn e Mo para aplicações em células a combustível e obteve como resultado que o método de redução de álcool para obtenção de catalisadores, PtSn/C e PtSnMo/C, mostra-se eficaz para a oxidação do metanol. Notou também a existência de fase de $\mathrm{SnO}_{2}$ nos catalisadores de PtSn o que dificultou a identificação do sinal característico da formação da liga, porém a presença de Sn na varredura linear mostrou picos poucos definidos, sugerindo a oxidação completa de diferentes formas de $\mathrm{CO}$ adsorvido e, consequentemente, a eficácia eletrocatalítica dos catalisadores. Além disso, os catalisadores sintetizados no trabalho foram ativos em baixos potenciais para oxidação do metanol, logo, estão dentro da faixa de potenciais aceita para aplicação tecnológica. No estudo, o catalisador PtSnMo/C apresentou maior atividade catalítica, com o valor de corrente acima dos demais em todos potenciais estudados, mostrando que não houve competição entre os metais formadores do catalisador terciário e que coexistiram e somaram seus efeitos catalíticos, permitindo maior rendimento em relação aos demais, podendo ter aplicação prática em célula a combustível.

Shao[32] fez uma revisão sobre as reações de redução do oxigênio e de oxidação do hidrogênio em $\mathrm{CaC}$ tipo PEM e de oxidação direta do metanol usando catalisadores eletroquímicos à base de $\mathrm{Pd}$. Verificou que a substituição total ou parcial da Pt pelo $\mathrm{Pd}$ em $\mathrm{CaC}$ de baixa temperatura, melhora o desempenho do ânodo no processo de oxidação tanto do $\mathrm{H}_{2}$ quanto de combustíveis contendo $\mathrm{CO}$. No processo de redução do oxigênio (RRO) observou que esta reação depende fortemente da orientação da superfície do Pd e que com Pd (100) deve exibir uma atividade catalítica elevada. Além disso, os catalisadores eletroquímicos à base PtPd apresentaram uma durabilidade muito maior quando comparados aos metais de transição para as reações de RRO.

Antolini et al. ${ }^{[33]}$ estudaram catalisadores eletroquímicos à base de $\mathrm{Pd}$ e Co para reduzir a quantidade de platina nas membranas de $\mathrm{CaC}$ tipo PEM. Verificaram que numa composição atômica de Pd:Pt:Co de 72:26:2 (ânodo+cátodo) o desempenho da célula foi semelhante ao do catalisador com $100 \%$ de Pt. Observaram, também, que com um carregamento de $35 \%$ em peso da quantidade normal de Pt, a perda de eficiência foi de $6 \%$ no ânodo e de $5 \%$ no cátodo. A 
densidade de potência máxima da célula com Pd, Pt e Co ficou em $76 \%$ da densidade alcançada nas células com eletrodo de Pt.

Othman et. al. ${ }^{[34]}$ realizaram uma breve discussão e análise sobre os principais metais não nobres empregados em catalisadores eletroquímicos à base de carbono para CaC. Observaram que as células PEM, que operam em baixa temperatura, exigem a utilização de catalisadores altamente ativos para promover tanto a reação de oxidação do combustível no ânodo $(\mathrm{ROH})$ quanto de redução do oxigênio no cátodo (RRO), proporcionando atividade catalítica. Para que as perdas de tensão no interior da célula sejam minimizados, torna-se necessário o desenvolvimento de catalisadores eletroquímicos alternativos. Notaram que, embora nenhum catalisador apresente desempenho e durabilidade comparável aos de $\mathrm{Pt} / \mathrm{C}$, os confeccionados com metais de transição suportados em carbono apresentam atividade eletrocatalítica razoável e que os catalisadores nanoestruturados de ferro e nitrogênio à base carbono estão começando a surgir como possíveis candidatos para futuros sistemas comerciais de células PEM.

Outros sistemas de catalisadores eletroquímicos têm sido estudados, entre estes sistemas estão os baseados em platina e terras raras para oxidação de metanol (Oliveira Neto et.al..[35) e etanol (Oliveira Neto et.al.[36]), os quais apresentaram resultados promissores.

Piasentin et. al. ${ }^{[37]}$ prepararam catalisadores eletroquímicos de $\mathrm{Pt} / \mathrm{C}$ $\mathrm{Sb}_{2} \mathrm{O}_{5} . \mathrm{SnO}_{2}, \mathrm{PtPd} / \mathrm{C}-\mathrm{Sb}_{2} \mathrm{O}_{5} . \mathrm{SnO}_{2}$ e $\mathrm{PtPdSn} / \mathrm{C}-\mathrm{Sb}_{2} \mathrm{O}_{5} . \mathrm{SnO}_{2}$ pelo método de redução por borohidreto usando $\mathrm{H}_{2} \mathrm{PtCl}_{6} .6 \mathrm{H}_{2} \mathrm{O}, \mathrm{Pd}\left(\mathrm{NO}_{3}\right)_{2} .2 \mathrm{H}_{2} \mathrm{O}$ e $\mathrm{SnCl}_{2} .2 \mathrm{H}_{2} \mathrm{O}$ como fontes de metal e uma mistura física de $85 \%$ de carbono Vulcan $\mathrm{XC72}$ e $15 \%$ de $\mathrm{Sb}_{2} \mathrm{O}_{5} . \mathrm{SnO}_{2}$ (óxido de antimónio e estanho - ATO) como suporte. Os difratogramas de raios-X mostraram a formação de liga Pt-Pd-Sn (CFC), e que fases de $\mathrm{Sb}_{2} \mathrm{O}_{5} \mathrm{SnO}_{2}$ estão presentes no catalisador eletroquímico $\mathrm{PtPdSn} / \mathrm{C}-\mathrm{Sb}_{2} \mathrm{O}_{5} . \mathrm{SnO}_{2}$. As micrografias obtidas por microscopia eletrônica de transmissão para todos os catalisadores eletroquímicos mostraram que as nanopartículas metálicas foram homogeneamente distribuídas ao longo dos suportes com tamanhos médios de partícula no intervalo de 3-5 nm. A oxidação eletroquímica de etanol foi estudada por voltametria cíclica e cronoamperometria a $25^{\circ} \mathrm{C}$ e em um uma célula DEFC a $100^{\circ} \mathrm{C}$ e, neste caso, o catalisador $\mathrm{PtPdSn} / \mathrm{C}-\mathrm{Sb}_{2} \mathrm{O}_{5} . \mathrm{SnO}_{2}$ apresentou desempenho superior para a 
oxidação eletroquímica do etanol em relação aos $\mathrm{PtPd} / \mathrm{C}-\mathrm{Sb}_{2} \mathrm{O}_{5} . \mathrm{SnO}_{2}$ e Pt/C$\mathrm{Sb}_{2} \mathrm{O}_{5} . \mathrm{SnO}_{2}$, respectivamente. Os estudos de FTIR in situ mostraram que o ácido acético e $\mathrm{O}_{\mathrm{CO}_{2}}$ são preferencialmente formados quando do uso do catalisador eletroquímico PtPdSn/C-Sb2 $\mathrm{O}_{5} . \mathrm{SnO}_{2}$.

Nandenha et. al. ${ }^{[38]}$ prepararam catalisadores de $\mathrm{Pd} / \mathrm{C}-\mathrm{Sb}_{2} \mathrm{O}_{5} \cdot \mathrm{SnO}_{2}$ e $\mathrm{PdAu} / \mathrm{C}$ $\mathrm{Sb}_{2} \mathrm{O}_{5} \cdot \mathrm{SnO}_{2}$ com diferentes razões atômicas (Pd:Me: 90:10, 70:30, e 50:50, onde $\mathrm{Me}$ é o metal) pelo método de redução por borohidreto e caracterizaram-os por difração de raio-X, microscopia eletrônica de transmissão, voltametria cíclica, cronoamperometria e teste de desempenho em célula a combustível direta de ácido fórmico a $100^{\circ} \mathrm{C}$. Os difratogramas de raio-X mostraram que a fase metálica $\mathrm{Pd} / \mathrm{C}$ $\mathrm{Sb}_{2} \mathrm{O}_{5} \cdot \mathrm{SnO}_{2}$ e $\mathrm{PdAu} / \mathrm{C}-\mathrm{Sb}_{2} \mathrm{O}_{5} \cdot \mathrm{SnO}_{2}$ apresentam estrutura cúbica de fase centrada. As microscopias eletrônicas de varredura e histogramas mostraram que para todos os catalisadores eletroquímicos na forma de nanopartículas não estavam bem dispersas sobre o suporte e houve a formação de alguns aglomerados. As atividades eletroquímicas mostraram que o catalisador $\mathrm{PdAu} / \mathrm{C}-\mathrm{Sb}_{2} \mathrm{O}_{5} \cdot \mathrm{SnO}_{2}$ (70:30) apresentou um melhor desempenho para oxidação eletroquímica do ácido fórmico quando comparado com os outros catalisadores a uma temperatura de $25^{\circ} \mathrm{C}$, enquanto que o $\mathrm{PdAu} / \mathrm{C}-\mathrm{Sb}_{2} \mathrm{O}_{5} \cdot \mathrm{SnO}_{2}(90: 10)$ mostrou um desempenho maior para oxidação eletroquímica a ácido fórmico a uma temperatura de $100^{\circ} \mathrm{C}$. Estes resultados indicaram que a adição de 10 a $30 \%$ de $\mathrm{Au}$ nos catalisadores eletroquímicos de $\mathrm{Pd}$ favoreceu a oxidação eletroquímica do ácido fórmico. Este efeito pode ser atribuído à sinergia entre os constituintes dos catalisadores eletroquímicos (metais $\mathrm{Pd}$ e $\mathrm{Au}, \mathrm{SnO}_{2}, \mathrm{Sb}_{2} \mathrm{O}_{5}$ e $\mathrm{SnO}_{2}$ ).

Sarto et. al. ${ }^{[39]}$ estudaram catalisadores eletroquímicos de $\mathrm{Pd} / \mathrm{C}$ para aplicações em células $\mathrm{CaC}$ preparados por eletrodeposição galvanostática e pulverização do paládio em camada de difusão gasosa. O estudo destes catalisadores deve-se à alta atividade catalítica do paládio e por este apresentar menor custo em relação ao sistema que comumente utiliza platina como base. Diferentes amostras foram preparadas variando a carga de Pd. A morfologia da superfície foi investigada por microscopia eletrônica de varredura. As voltametrias cíclicas em solução ácida permitiram estudar o comportamento catalítico das amostras e sua evolução com o aumento do número de ciclos. Os resultados mostraram que, dependendo da técnica e da quantidade de pulverização do metal, a 
particula cresceu com diferentes formas e comportamentos eletroquímicos distintos, cujos valores de superfícies eletroativas variam de algumas dezenas a algumas centenas de $\mathrm{m}^{2} \cdot \mathrm{g}^{-1}$.

\subsubsection{Mecanismo bifuncional e efeito eletrônico}

O mecanismo bifuncional consiste em utilizar um metal menos nobre $(M=S n$, $\mathrm{Ru}$ entre outros) em conjunto com a platina, para que este forneça na superfície do catalisador espécies contendo oxigênio (oxi-hidróxidos) que atuam como um oxidante químico, levando o $\mathrm{CO}$ a $\mathrm{CO}_{2}$ e liberando o sítio catalítico da platina para uma nova adsorção ${ }^{[1,19]}$. De acordo com o mecanismo bifuncional (mecanismo promovido), a espécie reagente $\left(\mathrm{H}_{2}\right)$ e o contaminante (CO) adsorvem-se preferencialmente nos átomos de Pt (Eq. 4-6), enquanto que o outro metal, menos nobre e consequentemente mais oxidável ( $M=S n, R u$ etc), produz espécies oxigenadas ou óxidos hidratados que atuam diretamente na oxidação do contaminante (Eq. 7 e 8) $)^{[19]}$

$$
\begin{aligned}
& \mathrm{H}_{2}+2 \mathrm{Pt} \Leftrightarrow 2 \mathrm{Pt}-\mathrm{H} \\
& \mathrm{Pt}-\mathrm{H} \Leftrightarrow \mathrm{Pt}+\mathrm{H}^{+}+e^{-} \\
& \mathrm{CO}+\mathrm{Pt} \Leftrightarrow \mathrm{Pt}-\mathrm{CO} \\
& \mathrm{M}+\mathrm{H}_{2} \mathrm{O} \Leftrightarrow \mathrm{M}-\mathrm{OH}+\mathrm{H}^{+}+e^{-} \\
& \mathrm{Pt}-\mathrm{CO}+\mathrm{M}-\mathrm{OH} \Leftrightarrow \mathrm{Pt}+\mathrm{M}+\mathrm{CO}_{2}+H^{+}+e^{-}
\end{aligned}
$$

O efeito eletrônico baseia-se na modificação das propriedades eletrônicas da platina por um segundo metal causando um decréscimo na força de ligação do $\mathrm{CO}$ com a superfície do catalisador ${ }^{[19,40]}$. Ou seja, a modificação nas propriedades eletrônicas promove o esvaziamento ou preenchimento da banda $5 \mathrm{~d}$ da platina causado pela interação com o segundo ou terceiro metal do sistema catalítico ${ }^{[19]}$ ou pela dependência desse parâmetro com o tamanho de partícula ${ }^{[19,40]}$. 


\subsection{Células a combustível a álcool direto}

Diferentes combustíveis podem ser usados na oxidação, como $\mathrm{H}_{2}$, metanol, etanol, EG, entre outros, e na redução $\circ \mathrm{O}_{2}$ ou do próprio ar. Os combustíveis líquidos são os mais adequados para uso, pois são mais fáceis de armazenar e de fácil distribuição, além de oferecerem menor risco de acidente, quando comparados ao $\mathrm{H}_{2}$.

Os combustíveis líquidos para serem considerados eficientes devem apresentar um alto índice de conversão a $\mathrm{CO}_{2}$, e terem baixa formação de intermediários como o $\mathrm{CO}$ que provoca o envenenamento da platina com conseqüente perda de atividade catalítica.

\subsubsection{Oxidação eletroquímica do Metanol}

O metanol, apesar de ser amplamente estudado para $\mathrm{CaC}$ de oxidação direta (DAFC - Direct Alcohol Fuel Cell), apresenta algumas desvantagens como ser altamente tóxico e inflamável, ter um baixo ponto de ebulição $\left(65^{\circ} \mathrm{C}\right)$ e alto índice de crossover. O crossover representa um dos maiores problemas no uso do metanol, pois a mistura metanol + água atravessa a membrana polimérica causando uma perda significativa de atividade no cátodo. No entanto, devido a sua baixa complexidade molecular além de apresentar os melhores resultados com o emprego de catalisadores eletroquímicos de PtRu/C e com outros catalisadores, a reação de oxidação do metanol tem sido objeto de estudo de diversos autores ${ }^{[41-45]}$. Estes estudos mostraram que a oxidação do metanol em meio ácido levou a formação de intermediários $\left(\mathrm{HCHO}, \mathrm{CO}_{a d s}, \mathrm{HCOOH}\right)$ e que estes produtos ligam-se aos sítios da platina limitando a cinética da oxidação, ou seja, diminuindo as taxas de reação.

A oxidação do metanol em meio alcalino possui uma cinética mais rápida com formação de intermediários contendo carbono quimissorvido, como - $(\mathrm{CHO})_{\text {ads, }} \mathrm{CO}_{\text {ads }}$ e $\mathrm{OH}_{\text {ads. }} \mathrm{A}$ remoção do $\mathrm{CO}_{\text {ads }}$ é favorecida pela grande quantidade de grupos hidroxilas. 
Uma célula alcalina operando diretamente com metanol apresenta as seguintes reações:

Ânodo: $\mathrm{CH}_{3} \mathrm{OH}+6 \mathrm{OH}^{-} \leftrightarrow \mathrm{CO}_{2}+5 \mathrm{H}_{2} \mathrm{O}+6 e^{-}$

Cátodo: $6 e^{-}+3 \mathrm{H}_{2} \mathrm{O}+3 / 2 \mathrm{O}_{2} \leftrightarrow 6 \mathrm{OH}^{-}$

Reação Global: $\mathrm{CH}_{3} \mathrm{OH}+3 / 2 \mathrm{O}_{2} \leftrightarrow \mathrm{CO}_{2}+2 \mathrm{H}_{2} \mathrm{O}$

\subsubsection{Oxidação eletroquímica do Etanol}

O etanol, apesar de ser interessante para o Brasil, por ser uma fonte renovável e já ter a facilidade do abastecimento, verifica-se que a quebra da ligação C-C por ser mais difícil durante o processo de oxidação e leva a formação de produtos intermediários ( $\mathrm{CO}$, acetaldeído e ácido acético) que são adsorvidos fortemente sobre a platina policristalina ocasionando a perda de atividade catalítica. Estudos por técnicas de espectrometria de massas eletroquímica diferencial (DEMS), espectroscopia de massas dessorção térmica eletroquímica (ECTDMS) e espectroscopia no infravermelho com transformada de Fourier in situ (FTIRS) são realizados na tentativa de desvendar os intermediários adsorvidos no catalisador eletroquímico durante a reação de oxidação do etano[[46-48].

Nos últimos anos, estudos mostraram que a oxidação do etanol em meio ácido levou a formação de acetaldeído, ácido acético, monóxido de carbono e dióxido de carbono. Verificou-se também que a oxidação do etanol em meio alcalino envolve várias etapas de reação e a oxidação completa leva a formação de $\mathrm{CO}_{2} \mathrm{e}$ produz 12 elétrons por molécula de álcool, já a oxidação incompleta produz 3 elétrons por molécula de acetato formada.

Uma célula alcalina operando diretamente com etanol apresentam as seguintes reações representadas pelas Eq. 12-14:

Ânodo: $\mathrm{C}_{2} \mathrm{H}_{5} \mathrm{OH}+12 \mathrm{OH}^{-} \leftrightarrow 2 \mathrm{CO}_{2}+9 \mathrm{H}_{2} \mathrm{O}+12 e^{-}$

Eq.12

Cátodo: $12 e^{-}+6 \mathrm{H}_{2} \mathrm{O}+3 \mathrm{O}_{2} \leftrightarrow 12 \mathrm{OH}^{-}$

Eq.13

Reação Global: $\mathrm{C}_{2} \mathrm{H}_{5} \mathrm{OH}+3 \mathrm{O}_{2} \leftrightarrow 2 \mathrm{CO}_{2}+3 \mathrm{H}_{2} \mathrm{O}$ 


\subsubsection{Oxidação eletroquímica do Etileno glicol}

O etileno glicol $\left(\mathrm{C}_{2} \mathrm{H}_{6} \mathrm{O}_{2}\right)$ em meio alcalino gera como intermediários oxalatos, glioxalato, glicolato, glicoaldeído, glioxal e dióxido de carbono e é considerado um transportador de energia para as células a combustível. A importância deste combustível deve-se ao baixo peso molecular, é obtido a partir da biomassa, apresenta uma alta densidade energética, alto ponto de ebulição $\left(198{ }^{\circ} \mathrm{C}\right)$ e menos tóxico que o metanol[49,50]. A densidade energética do etileno glicol é, aproximadamente $5,2 \mathrm{kWh} \cdot \mathrm{kg}^{-1}$, valor próximo a densidade energética do metanol $6,1 \mathrm{kWh} \cdot \mathrm{kg}^{-1}$ e do etanol, $8,6 \mathrm{kWh} \cdot \mathrm{kg}^{-1}$.

Comparando-se o EG com os outros alcoóis (TAB. 2), observa-se que os valores da entalpia e da energia livre padrões são maiores que os do metanol, sendo o potencial padrão próximo ao do metanol. Quando comparado ao etanol, os valores de $\Delta \mathrm{H}^{\circ} \mathrm{C}$ e $\Delta \mathrm{G}^{\circ} \mathrm{C}$ são próximos, mas o potencial padrão é bem menor. Portanto, o EG possui características que o levam à categoria de alcoóis aplicáveis em $\mathrm{CaC}$ de oxidação direta.

TABELA 2 - Valores de entalpia e energia livre padrões para a reação de combustão dos alcoóis e potencial padrão do eletrodo.

\begin{tabular}{|c|c|c|c|c|}
\hline Composto & $\begin{array}{c}\Delta \mathrm{H}^{\circ} \mathrm{c} \\
\left(\mathrm{kJ} . \mathrm{mol}^{-1}\right)\end{array}$ & $\begin{array}{c}\Delta \mathrm{G}^{\circ} \mathrm{c} \\
\left(\mathrm{kJ} . \mathrm{mol}^{-1}\right)\end{array}$ & $\begin{array}{c}\mathrm{E}^{\circ} \\
(\mathrm{mV})\end{array}$ & $\begin{array}{l}\mathrm{CO}_{2} \\
\left(e^{-}\right)\end{array}$ \\
\hline Metanol $\left(\mathrm{CH}_{3} \mathrm{OH}\right)$ & $-725,65$ & $-701,69$ & 18 & 6 \\
\hline Etanol $\left(\mathrm{CH}_{3} \mathrm{CH}_{2} \mathrm{OH}\right)$ & $-1364,5$ & $-1324,09$ & 90 & 12 \\
\hline Etilenoglicol $\left(\mathrm{HOCH}_{2} \mathrm{CH}_{2} \mathrm{OH}\right)$ & $-1188,5$ & $-1175,9$ & 10 & 10 \\
\hline
\end{tabular}

\subsubsection{Mecanismo de oxidação eletroquímica do etileno glicol}

No estudo da catálise de alcoóis de cadeia pequena como o EG, a grande dificuldade está na ruptura da ligação $C-C$, esta ruptura é necessária para que o álcool se oxide totalmente a $\mathrm{CO}_{2}$ alcançando, assim, o seu rendimento energético máximo. 
$\mathrm{Na}$ oxidação direta do EG são liberados 10 elétrons $\left(e^{-}\right)$por molécula, como pode ser visto na reação abaixo (Eq.15):

$\mathrm{C}_{2} \mathrm{H}_{6} \mathrm{O}_{2}+2 \mathrm{H}_{2} \mathrm{O} \rightarrow 2 \mathrm{CO}_{2}+10 \mathrm{H}^{+}+10 e^{-}$

No entanto, a oxidação do EG pode ocorrer via reações paralelas - oxidação incompleta - (FIG. 2), produzindo subprodutos diminuindo a densidade energética do EG, conforme o esquema de reações a seguir:

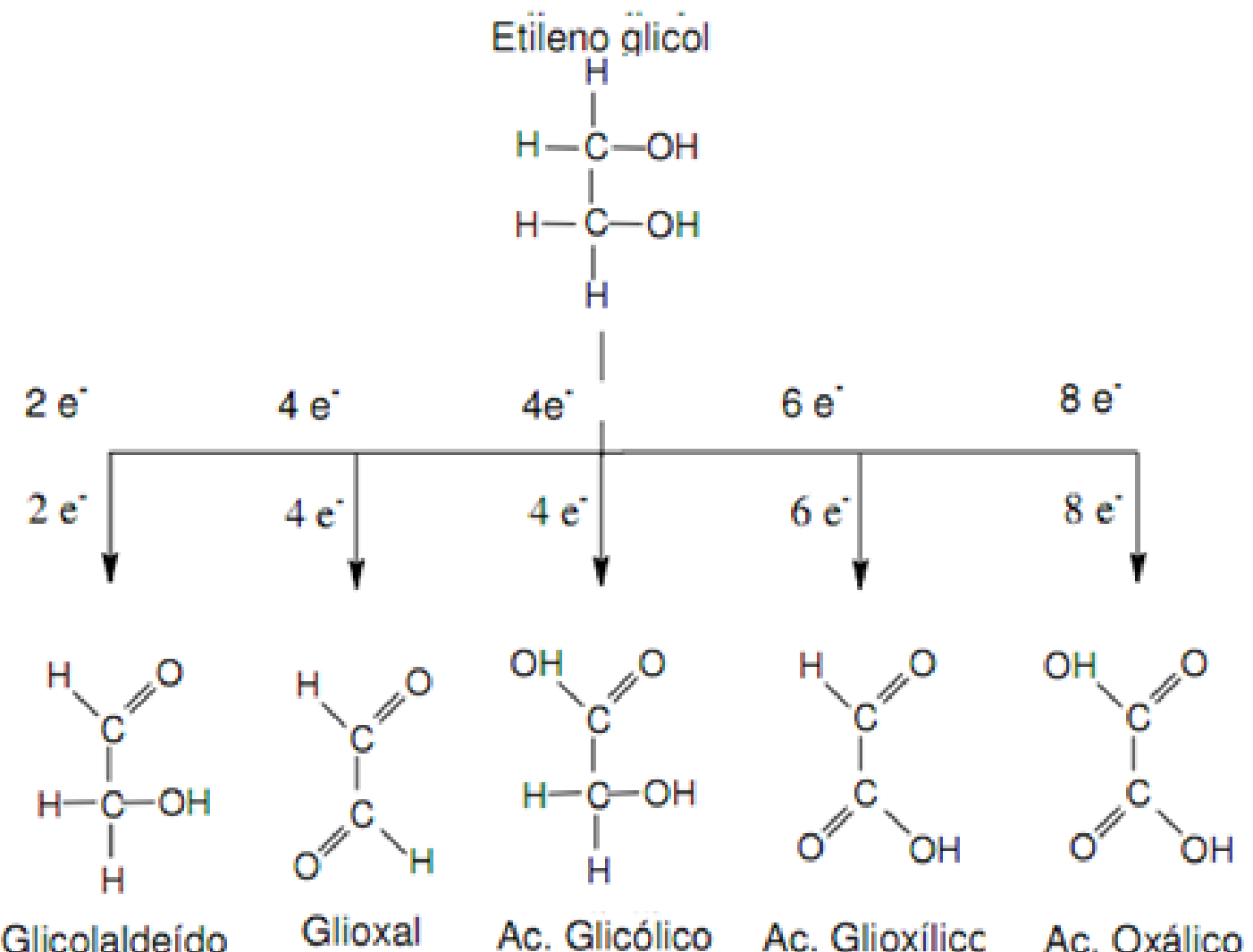

FIGURA 2 - Representação esquemática das diferentes vias para oxidação do etileno glicol ${ }^{[50] .}$

Uma célula a combustível alcalina que utiliza EG apresenta as seguintes reações quimicas (Eq. 16-18):

Ânodo: $\left.\mathrm{C}_{2} \mathrm{H}_{6} \mathrm{OH}\right)_{2}+10 \mathrm{OH}^{-} \leftrightarrow 2 \mathrm{CO}_{2}+8 \mathrm{H}_{2} \mathrm{O}+10 e^{-}$

Eq.16

Cátodo: $10 e^{-}+5 \mathrm{H}_{2} \mathrm{O}+5 / 2 \mathrm{O}_{2} \leftrightarrow 100 \mathrm{H}^{-}$

Reação Global: $\left.\mathrm{C}_{2} \mathrm{H}_{6} \mathrm{OH}\right)_{2}+5 / 2 \mathrm{O}_{2} \leftrightarrow 2 \mathrm{CO}_{2}+3 \mathrm{H}_{2} \mathrm{O}$

Eq.18 
Christensen e Hammer ${ }^{[51]}$ estudaram a oxidação eletroquímica do EG em meio ácido e básico utilizando a voltametria e a espectroscopia de infravermelho em eletrodos de platina lisa. Sugeriram dois mecanismos possíveis para a oxidação eletroquímica do EG em meio alcalino, sendo que a via preferencial produz como produto final o $\mathrm{CO}_{3}^{-2}$, e a via paralela o oxalato.

Ureta-Zañartu et al.[52] estudaram a oxidação do EG em eletrodepósitos de Pt, $\mathrm{Pt}-\mathrm{Pb}$ e Pt-Ir em substrato de titânio em meio ácido usando a voltametria cíclica. Apesar de todos os catalisadores eletroquímicos apresentarem baixa atividade, 0 eletrodo de Pt-Ir mostrou um melhor desempenho de corrente, o que levou a concluir que o Ir pode contribuir na formação de espécies oxigenadas.

Kaleidopolou et al.[53] estudaram a oxidação eletroquímica do EG sobre catalisadores eletroquímicos de PtRu, PtSn e PtRuSn em substrato de carbono vítreo. Foi observada uma maior estabilidade na corrente no eletrodo PtSn, pois neste eletrodo houve uma perda de $23 \%$ na densidade de corrente após 10 min de oxidação, enquanto que com os outros catalisadores ocorreu uma perda de até $49 \%$.

Weaver et al. ${ }^{[54]}$ estudaram a oxidação eletroquímica do EG em meio alcalino através das técnicas de voltametria cíclica e espectroscopia de infravermelho em eletrodos policristalinos de platina, ouro e níquel. Sugeriram que o eletrodo de platina produz glicolato, oxalato e carbonato. A formação de carbonato indicaria a ruptura da ligação $\mathrm{C}-\mathrm{C}$.

Silva ${ }^{[55]}$ estudou a oxidação eletroquímica do EG sobre catalisadores eletroquímicos de $\mathrm{Pt} / \mathrm{C}, \mathrm{PtRuO}_{2} / \mathrm{C}$ e $\mathrm{PtRu} / \mathrm{C}$ em solução ácida, utilizandos as técnicas de voltametria cíclica e de cronoamperometria. O comportamento voltamétrico destes eletrodos mostrou que os potenciais de início de reação são deslocados para valores menos positivos na ordem: PtRu/C < Pt0;75(RuO2)0;25/C < $\mathrm{Pt} / \mathrm{C}$; e, que em potenciais acima de $0 ; 7 \mathrm{~V}$ vs $\mathrm{ERH}$; o eletrodo de $\mathrm{PtRuO} / \mathrm{C}$ apresentou os maiores valores de corrente. Os cronoamperogramas em $0,6 \mathrm{~V}$ vs $\mathrm{ERH}$; confirmaram o melhor desempenho faradáico do eletrodo $\mathrm{PtRu} / \mathrm{C}$; com valores de densidade de corrente da ordem de 18;5 $\mu \mathrm{A} \mathrm{cm}^{-2}$; e a ordem de atividade encontrada foi: $\mathrm{Pt} / \mathrm{C}<\mathrm{Pt0} ; 75\left(\mathrm{RuO}_{2}\right) 0 ; 25 / \mathrm{C}<\mathrm{PtRu} / \mathrm{C}$. Os resultados indicaram um 
efeito catalítico na oxidação de $\mathrm{EG}$ com adição de $\mathrm{RuO}_{2}$ ou $\mathrm{Ru}$. Este aumento na atividade eletrocatalítica pode ser atribuído ao fato do rutênio apresentar baixa energia de ativação da água em baixos potenciais; fornecendo o oxigênio externo para a oxidação do CO; segundo o mecanismo bifuncional. Por outro lado, o melhor desempenho dos eletrodos contendo rutênio pode ser associado ao desvio para rotas reacionais rápidas, em que a ligação $\mathrm{C}-\mathrm{C}$ permaneça intacta como na formação de glicolaldeído.

Oliveira Neto et al. ${ }^{[56]}$ estudaram a oxidação eletroquímica do EG em eletrodos binários de PtRu e PtSn e ternários de PtRuSn suportados em carbono em meio $\mathrm{H}_{2} \mathrm{SO}_{4}$ 0,5 mol. $\mathrm{L}^{-1}$. Os resultados da voltametria de varredura linear mostraram um melhor desempenho do catalisador eletroquímico de PtSn, com uma corrente de cerca de 2,5 A.g $\mathrm{Pt}^{-1}$ obtida na cronoamperometria.

Demarconnay et al. ${ }^{[57]}$ estudaram a oxidação eletroquímica do EG em meio alcalino sobre catalisadores eletroquímicos de Pt/C, PtPd/C, PtBi/C e PtPdBi/C. Verificaram que a introdução de outros metais com a $\mathrm{Pt}$ diminui a capacidade catalítica para a ruptura da ligação C-C, concluindo que estes diminuíam os átomos de Pt na superfície do catalisador. Para os catalisadores eletroquímicos com $\mathrm{Pd}$ e Bi observaram um melhor desempenho em relação ao $\mathrm{Pt} / \mathrm{C}$. A provável explicação é que o Bi favorece o mecanismo bifuncional, ou seja, oferece espécies oxigenadas, enquanto o álcool é adsorvido nos sítios da platina em potenciais mais baixos que 0 da platina, favorecendo a oxidação do $\mathrm{CO}$ a $\mathrm{CO}_{2}$.

Livshits et at. ${ }^{[58]}$ apresentaram o desempenho de uma célula a combustível direta de EG (DEGFC) durante sua oxidação eletroquímica e os produtos intermediários formados. Publicaram que durante o funcionamento da célula numa solução à base de ácido tríflico $\left(\mathrm{CF}_{3} \mathrm{SO}_{3} \mathrm{H}\right)$ o desempenho foi de: $120 \mathrm{~mW} . \mathrm{cm}^{-2}(\mathrm{em} \mathrm{t}$ $=0 \mathrm{~h})$ e que este diminui para 50 e $43 \mathrm{~mW} \cdot \mathrm{cm}^{-2}$ após 2 hrs e 15,5 hrs, respectivamente. $\mathrm{E}$, numa solução de ácido sulfúrico o desempenho foi de 36 para $27 \mathrm{~mW} . \mathrm{cm}^{-2}$ após 2 hrs e 22,5 hrs de funcionamento, respectivamente. Usando esta célula encontraram dois principais subprodutos da oxidação do EG, os ácidos glicólicos e oxálicos, e notaram que suas concentrações aumentaram durante os dois turnovers (reutilização) do combustível até chegarem a valores constantes. Durante a experiência, a concentração de EG foi mantida em $0,5 \mathrm{~mol} \cdot \mathrm{L}^{-1}$, após 10 
turnovers do combustível, no final dos quais apenas pequenas quantidades de ácido glicólico e oxálico permaneceu na solução. Este resultado, juntamente com resultados eletroquímicos realizados (potenciostático) demonstrou uma alta eficiência do combustível EG, provando ser um excelente candidato para muitas aplicações em CaC.

Zhao et al. ${ }^{[59]}$ estudaram o desempenho de uma célula a combustível direta de EG com uma membrana de troca aniônica (anion exchange membrane AEMDEGFCs). Neste artigo foram desenvolvidos catalisadores eletroquímicos sem a presença de platina com o objetivo de investigar os efeitos das condições de funcionamento, incluindo a concentração de $\mathrm{EG}$, a concentração de $\mathrm{KOH}$, a taxa de combustível, o suprimento de oxigênio e a temperatura de funcionamento da célula. $\mathrm{O}$ resultado experimental mostrou que testes em célula para o eletrodo PdNi produziu uma densidade de potência máxima de $67 \mathrm{~mW} . \mathrm{cm}^{-2} \mathrm{com}$ uma densidade de corrente de $225 \mathrm{~mA} . \mathrm{cm}^{-2}$ a $60{ }^{\circ} \mathrm{C}$ mostrando ser um desempenho satisfatório para as $\mathrm{CaC}$ alimentadas com EG. O elevado desempenho foi atribuído ao aumento das cinéticas tanto da reação de oxidação do EG, quanto da reação de redução do oxigênio e aos parâmetros operacionais; concentração do $E G$, do $\mathrm{KOH}$ e da temperatura de funcionamento das $\mathrm{CaC}$; fatores que apresentaram influências significativas.

Sieben e Duarte ${ }^{[60]}$ estudaram catalisadores de Pt e Pt-Ru contendo diferentes quantidades de rutênio (entre 19 e 30\% em massa) preparados por eletrodeposição. O teste da oxidação eletroquímica dos combustíveis metanol, etanol e EG com o eletrólito de $\mathrm{H}_{2} \mathrm{SO}_{4}$ mostrou que a atividade eletrocatalítica do catalisador bimetálico com 30\% em massa de Ru apresenta-se mais ativa. Este comportamento pode estar associado: a um efeito sinérgico entre a oxidação do álcool, via oxigênio contendo espécies adsorvidas em átomos de $\mathrm{Ru}$, ao tamanho adequado da Pt e a modificação da estrutura eletrônica de átomos de Pt que enfraquece o nível de adsorção de $\mathrm{CO}$ e de outros intermediários. 


\section{PROCEDIMENTO EXPERIMENTAL}

\subsection{Síntese dos catalisadores eletroquímicos pelo método borohidreto}

Os catalisadores eletroquímicos à base de $\mathrm{Pt}, \mathrm{Pd}$ e $\mathrm{Sn}$ suportados em carbono foram preparados pelo método da redução via borohidreto que apresenta eficácia comprovada na produção de nanopartículas da ordem de $2 \mathrm{~nm}^{[7,25,61]}$, com carga metálica nominal de $20 \%$ em massa.

Utilizou-se ácido cloroplatínico hexahidratado $\left(\mathrm{H}_{2} \mathrm{PtCl}_{6} .6 \mathrm{H}_{2} \mathrm{O}\right.$ - Aldrich), cloreto de estanho dihidratado $\left(\mathrm{SnCl}_{2} .2 \mathrm{H}_{2} \mathrm{O}\right.$ - Aldrich) e nitrato de paládio dihidratado $\left(\mathrm{Pd}\left(\mathrm{NO}_{3}\right)_{2} 2 \mathrm{H}_{2} \mathrm{O}\right.$ - Aldrich) como fonte de metais, álcool 2-propanol (Merck) como solvente, borohidreto de sódio ( $\mathrm{NaBH}_{4}$ - Aldrich) como agente redutor, hidróxido de potássio ( $\mathrm{KOH}$ - Merck) como agente estabilizante para evitar a degradação do borohidreto de sódio e negro de fumo Vulcan® XC72 (Cabot) como suporte. Os precursores metálicos e o suporte de carbono foram adicionados, sob agitação, em uma solução 2-propanol/água com razão volumétrica igual a 50/50 (v/v). Após este processo adicionou-se uma solução contendo $10 \mathrm{~mL}$ de solução de $\mathrm{KOH}$ 0,01 mol.L-1 e $\mathrm{NaBH}_{4}$ (razão molar $\mathrm{NaBH}_{4}$ na proporção de 5:1). A solução resultante foi submetida à agitação por 20 minutos. O catalisador eletroquímico obtido foi filtrado a vácuo, lavado com 2 litros de água e seco a 70 ํ p por 2 horas.

Os catalisadores eletroquímicos foram preparados em diferentes proporções atômicas (a saber: Pt/C (100), Pd/C(100), Sn/C(100), PtSn/C (90:10, 70:30 e 50:50), PdSn/C (90:10, 70:30 e 50:50), PtPd/C (90:10, 70:30 e 50:50) . A FIG. 3 apresenta as etapas de preparação dos catalisadores eletroquímicos pelo método da redução via borohidreto de sódio. 


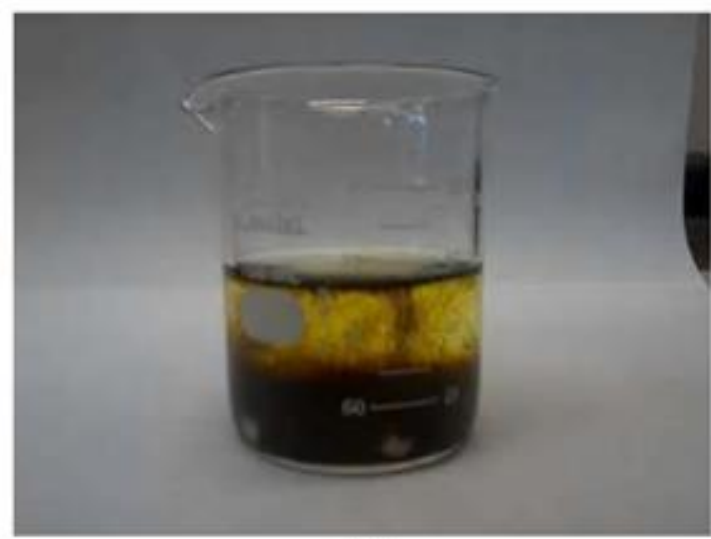

(a)

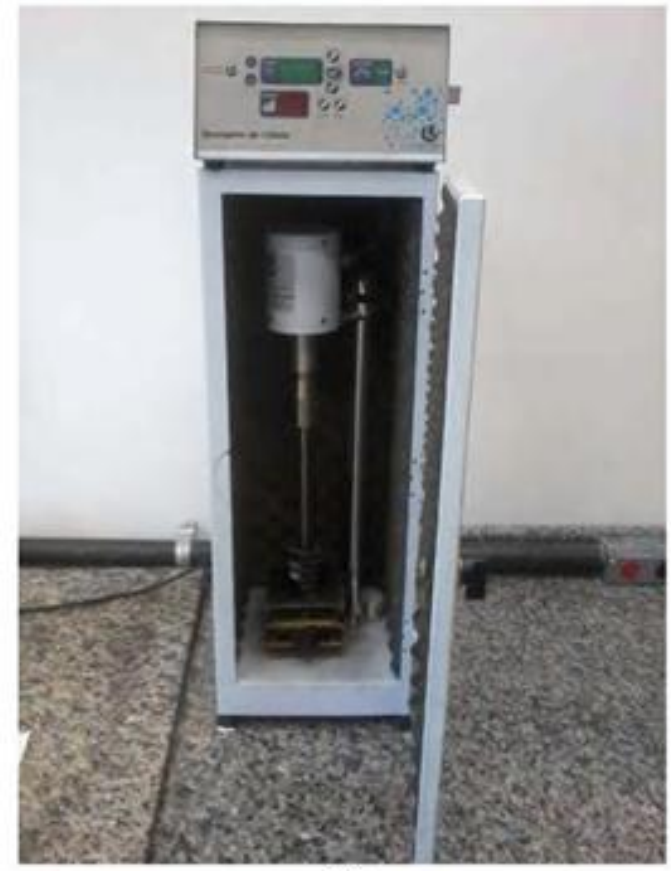

(c)

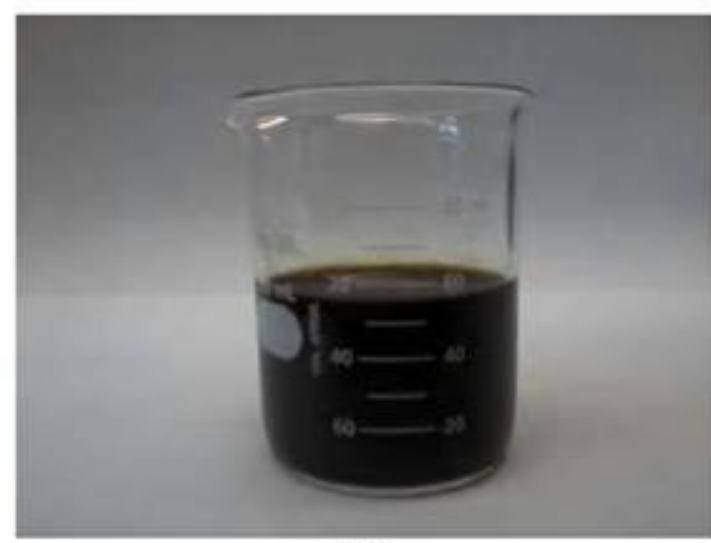

(b)

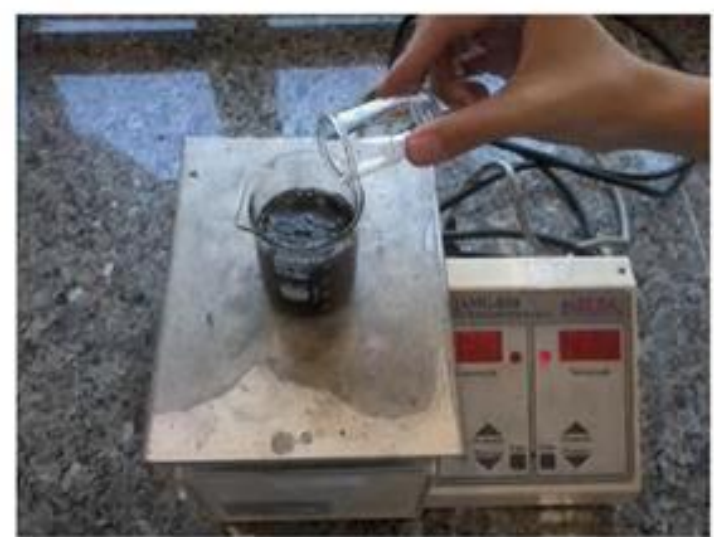

(d)

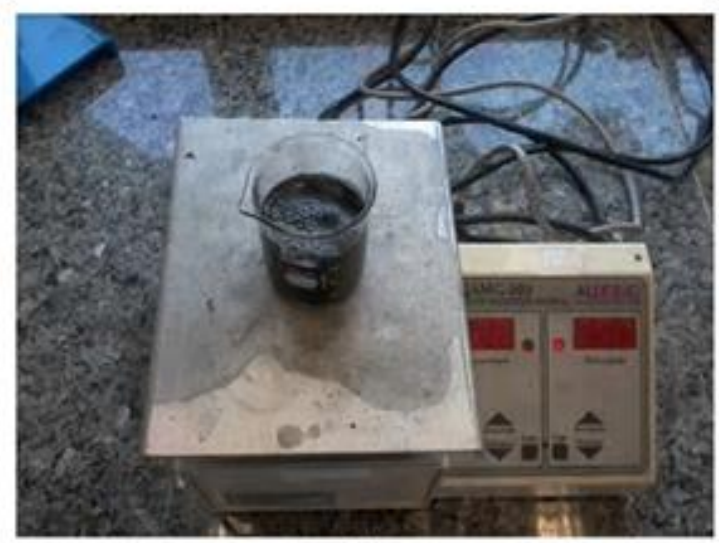

(e)

FIGURA 3 - Método da redução por borohidreto (a) mistura de água+ propanol +metais precursores, (b) adição de carbono e agitação, (c) sonificação da mistura, (d) adição de borohidreto de sódio e (e) agitação por 30 minutos ${ }^{[25]}$. 
A Fig. 4 apresenta um fluxograma que resume as etapas do método de redução via borohidreto e auxilia na compreensão da FIG. 3. Por este método de síntese é possível controlar o tamanho, a dispersão e a composição das partículas nanométricas e, de acordo com alguns estudos, ${ }^{[7,25]}$ esse método costuma formar mais ligas do que óxidos, quando comparado, por exemplo, ao método de redução por álcool.

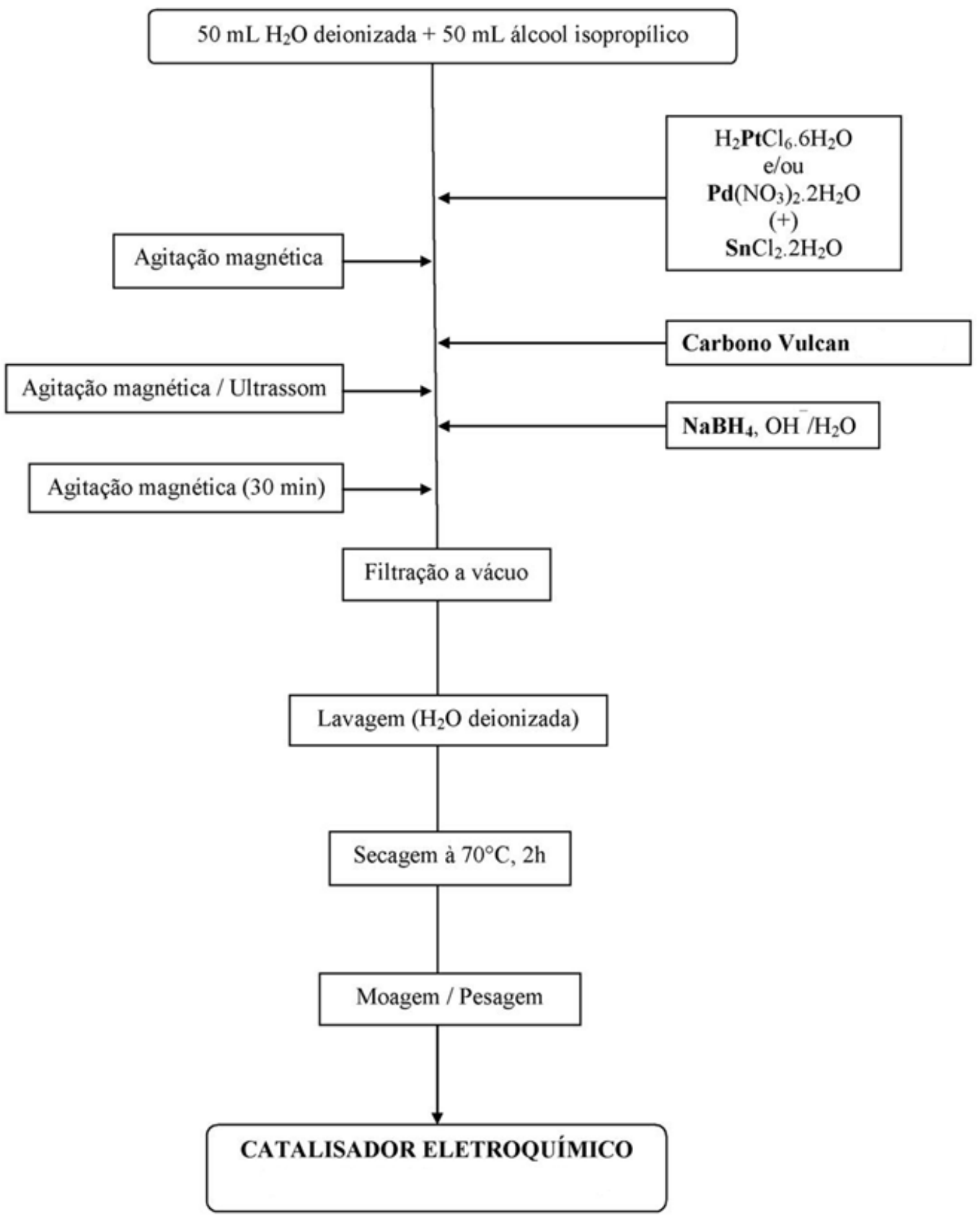

Figura 4 - Fluxograma do método de preparação de catalisadores eletroquímicos via redução por borohidreto de sódio[7] 


\subsection{Preparação dos eletrodos de camada fina porosa}

O eletrodo de camada fina porosa (FIG.5) foi preparado pela adição de $20 \mathrm{mg}$ do catalisador eletroquímico com 3 gotas de solução de Teflon a 5\% em $50 \mathrm{~mL}$ de água. A mistura resultante foi colocada em um sistema de ultrassom por 10 min para homogeneização. Após este período a mistura foi filtrada em um filtro microporo HAWP04700. A mistura ainda úmida foi retirada do filtro e colocada sobre a cavidade do eletrodo rotatório, sob leve pressão, procurando deixar a superfície o mais homogênea possível.

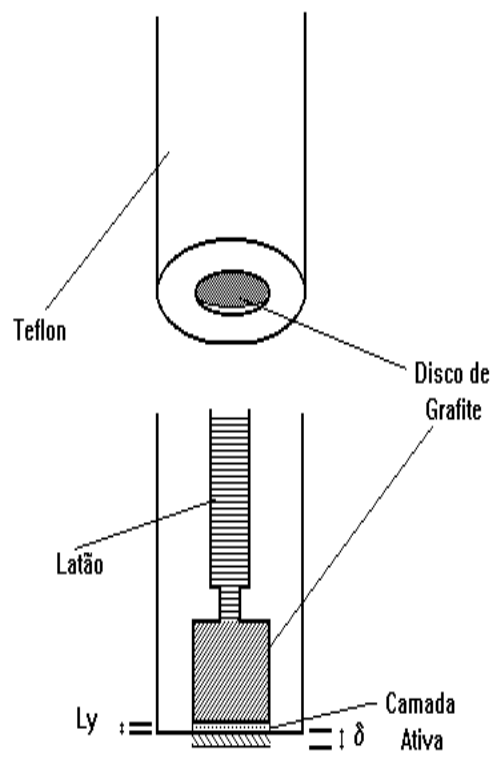

FIGURA 5 - Representação do eletrodo rotatório com camada fina porosa [62]

\subsection{Caracterização físico-química dos catalisadores eletroquímicos}

Os catalisadores eletroquímicos preparados foram caracterizados por difração de raios-X (DRX), espectroscopia de energia dispersiva de raios-X (EDX), e microscopia eletrônica de transmissão (MET). 


\subsubsection{Difração de Raios-X}

As análises dos difratogramas de raios-X permitem a obtenção de informações quanto à estrutura cristalina dos catalisadores e a estimativa do tamanho médio de cristalito da fase presente no catalisador através da equação de Scherrer (Eq.19). Para obter estas informações uma pequena quantidade do catalisador foi compactado em um suporte de vidro e as medidas realizadas em um difratômetro de raios $X$ da Rigaku modelo Miniflex II com fonte de radiação de CuKa $(\lambda=1,54056 \AA)$, varredura em $2 \theta$ de $20^{\circ}$ a $90^{\circ}$ com velocidade de varredura de $2^{\circ}$ $\min ^{-1}$. Para a estimativa do valor médio do diâmetro dos cristalitos do catalisador foi usada a equação de Scherrer (Eq.19) utilizando o pico de reflexão correspondente ao plano (220) da estrutura CFC da platina e suas ligas, pois no intervalo de $2 \theta$ entre $60^{\circ}$ e $75^{\circ}$ não há contribuições de outras fases ${ }^{[25]}$.

$$
\mathrm{d}=\frac{\mathrm{K} \cdot \lambda}{\beta \cdot \cos \theta}
$$

Onde $d$ é o diâmetro médio das partículas em angstroms, $K$ é uma constante que depende da forma dos cristalitos, neste trabalho foi utilizado o valor de $K=0,9$ admitindo-se cristalitos esféricos, $\lambda$ é o comprimento de onda da radiação usada, no caso do $\mathrm{Cu} \mathrm{Ka}, \lambda=1,54056 \AA$. Segundo a literatura o valor de $\beta$ pode ser dado, na prática, apenas como a largura a meia altura, em 26 radianos, do pico referente ao plano (220) da amostra medida e $\theta$ é o ângulo de Bragg em graus para o ponto de altura máxima do pico analisado (220).

Os parâmetros de rede para os catalisadores eletroquímicos foram calculados utilizando os valores do comprimento de onda da radiação usada $(\lambda)$ e do ângulo de Bragg $(\theta)$, em graus, para o ponto de altura máxima do pico analisado (220), a partir da Eq. 20.

$$
a_{\mathrm{cfc}}=\frac{\sqrt{2} \cdot \lambda}{\operatorname{sen} \theta}
$$

A limitação da técnica de DRX na caracterização de catalisadores eletroquímicos reside no fato de que as larguras dos picos aumentam com a diminuição do tamanho de partícula de tal forma que apenas partículas com um 
diâmetro maior que $2 \mathrm{~nm}$ podem ser determinadas. Além disso, somente fases cristalinas podem ser registradas, ou seja, fases amorfas existentes permanecem não detectadas no difratograma de raios $X$. O parâmetro de rede da fase CFC (estrutura cúbica de face centrada) da Pt pode ser calculado utilizando-se dados da posição angular de $\theta$ max na reflexão (220) dos difratogramas.

\subsubsection{Espectroscopia de energia dispersiva de raios-X (EDX)}

Para os estudos com a técnica de EDX uma camada fina do catalisador eletroquímico foi colocada em um suporte de alumínio pela prensagem do pó em uma fita dupla face, sendo que as análises foram realizadas no microscópio eletrônico de varredura Jeol, modelo JSM-6010LA. Foram coletados dados em três pontos distintos e aleatórios da amostra e o resultado final, apresentado neste trabalho, corresponde a uma média destes pontos.

Os dados obtidos pelas análises de espectroscopia de energia dispersiva de raios-X permitiram a obtenção de uma análise semi-quantitativa da composição química do catalisador.

\subsubsection{Microscopia eletrônica de transmissão (MET)}

Para as analises de microscopia eletrônica de transmissão foi utilizado um Microscópio Eletrônico de Transmissão JEOL modelo JEM-2100 (200kV). Neste estudo foi preparada uma suspensão de cada catalisador em 2-propanol, onde esta foi homogeneizada em um sistema de ultrassom. Posteriormente, uma alíquota da amostra foi depositada sobre uma grade de cobre $(0,3 \mathrm{~cm}$ de diâmetro) com um filme de carbono. Em média, foram tomadas 6 micrografias para cada amostra, de forma que a coleção de dados permitissem a construção de histogramas que representassem a distribuição do tamanho de partículas. Foram medidas cerca de 100 partículas em cada amostra para a construção dos histogramas e o cálculo do tamanho médio de partícula. 
Através da microscopia eletrônica de transmissão determina-se o grau de dispersão das nanopartículas no suporte de carbono, bem como o tamanho médio das nanopartículas, através da construção de histogramas.

\subsubsection{Espectroscopia no infravermelho com transformada de Fourier in situ (FTIR)}

Para a identificação dos produtos formados durante a oxidação eletroquímica do EG sobre os vários catalisadores preparados neste trabalho utilizou-se a técnica de espectroscopia de infravermelho com transformada de Fourier in situ (FTIR). Assim, com o auxilio de um potenciostato pode-se identificar o potencial de inicio de formação dos diferentes produtos da reação estudada e torna-se possível acompanhar esta distribuição em função do potencial de operação.

As medidas de ATR-FTIRS das espécies resultantes da oxidação do EG foram obtidas usando um espectrofotômetro Nicolet 6700 FT-IR equipado com um detector de banda larga linearizado MCT (telureto de cádmio e mercúrio) e acessório de reflectância atenuada (ATR PIKE MIRACLE), à temperatura ambiente, em meio básico de $1 \mathrm{~mol} . \mathrm{L}^{-1} \mathrm{KOH}$ e na presença de EG 1 mol.L-1. No acessório de ATR foi acoplado uma célula eletroquímica com três eletrodos: o catalisador eletroquímico como eletrodo de trabalho, um ERH como eletrodo de referência e uma placa de platina como contra-eletrodo. Os eletrodos de trabalho (área geométrica de $0,3 \mathrm{~cm}^{2}$ com uma profundidade de $0,3 \mathrm{~mm}$ ) foram preparados utilizando a técnica de revestimento da camada fina porosa, onde uma tinta é preparada com $20 \mathrm{mg}$ de catalisador e $100 \mu \mathrm{L}$ de solução de PTFE em $50 \mathrm{~mL}$ de água, em seguida disperso em banho ultra-sónico durante 5 minutos. Depois disso, a tinta é filtrada e todos os sólidos são depositados no eletrodo de trabalho.

As absorbâncias espectrais foram coletadas com a razão $R / R_{0}$, onde $R$ representa o espectro a um dado potencial, e Ro o espectro coletado para -0,85V . Os espectros foram coletados a cada $100 \mathrm{mV}$ a partir de $-0,85 \mathrm{~V}$ com 96 interferogramas por espectro entre $3000 \mathrm{~cm}^{-1}$ e $850 \mathrm{~cm}^{-1}$ com resolução de $8 \mathrm{~cm}^{-1}$. Inicialmente, um espectro de referência $\left(R_{0}\right)$ foi realizado a - 0,85 V, e os espectros 
das amostras foram obtidos após a aplicação de sucessivas etapas potenciais de 0,75 a $0,05 \mathrm{~V}$.

Estas análises forneceram informações que permitiram identificar os principais produtos da oxidação de EG com os diferentes catalisadores eletroquímicos, além de possibilitar um estudo comparativo a respeito de qual produto é favorecido em cada material.

\subsection{Caracterização eletroquímica dos catalisadores eletroquímicos}

Para a avaliação de desempenho dos catalisadores eletroquímicos na oxidação do EG foram utilizadas a voltametria cíclica (VC) e a cronoamperometria $(\mathrm{CA})$.

\subsubsection{Voltametria cíclica}

Os experimentos de voltametria cíclica (VC) foram realizados usando uma célula de três eletrodos: o catalisador como eletrodo de trabalho, um eletrodo de $\mathrm{Ag} / \mathrm{AgCl}$ como eletrodo de referência e uma placa de platina como contraeletrodo. Os experimentos foram executados em um Potenciostato/Galvanostato PGSTAT 30, marca AUTOLAB, acoplados a um computador. Foi utilizado como eletrólito suporte, solução $1,0 \mathrm{~mol} . \mathrm{L}^{-1}$ de $\mathrm{KOH}$. Os estudos foram feitos no intervalo de potencial de $0,05 \mathrm{~V}$ a $0,8 \mathrm{~V}$ com uma velocidade de varredura igual a $10 \mathrm{mV} \cdot \mathrm{s}^{-1}$. Os experimentos foram executados primeiro na ausência de EG e posteriormente na presença de EG na concentração de 1,0 mol.L-1, em solução saturada com $\mathrm{N}_{2}$ a temperatura ambiente.

Pela VC sem a presença de EG foram obtidos os perfis voltamétricos que permitiram comparar o desempenho catalítico entre os catalisadores eletroquímicos preparados por redução via borohidreto: Pt/C, PtSn/C, PdSn/C e PtPd/C com diferentes composições dos mesmos. 
As correntes dos voltamogramas cíclicos foram normalizadas por grama de platina ou de paládio, conforme a composição do catalisador, considerando que a adsorção do EG e a sua desidrogenação ocorrem somente em sítios de platina e/ou de paládio na temperatura ambiente.

\subsubsection{Cronoamperometria}

Os experimentos para avaliação da eletroatividade dos catalisadores eletroquímicos pela técnica de cronoamperometria (CA) têm como base a mesma montagem experimental dos experimentos voltamétricos e foram realizados a

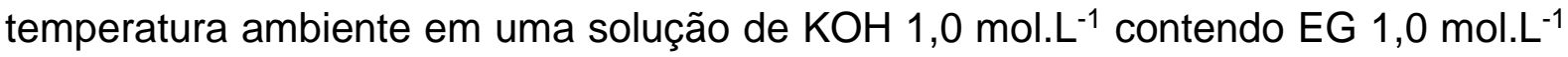
e saturada com $\mathrm{N}_{2}$. Esses estudos foram executados mediante a aplicação, no catalisador eletroquímico (eletrodo de trabalho) de um potencial de $500 \mathrm{mV}$ durante 30 minutos.

Pela CA verifica-se o comportamento da corrente em função do tempo, o que permite obter os valores de corrente próximos aos do estado estacionário, que são importantes para a operação em CaC.

As correntes dos voltamogramas cíclicos e curvas cronoamperométricas foram normalizadas por grama de platina ou de paládio, conforme a composição do catalisador, considerando que a adsorção do EG e a sua desidrogenação ocorrem somente em sítios da platina e/ou do paládio na temperatura ambiente.

\subsection{Testes em célula a combustível unitária}

O desempenho de uma célula a combustível se faz pelo estudo de sua curva de polarização, que relaciona o potencial da célula com a densidade de corrente. As curvas foram obtidas em uma célula unitária de $5 \mathrm{~cm}^{2}$ de área geométrica, com o oxigênio umidificado externamente usando uma garrafa umidificadora de temperatura controlada e aquecida a temperatura de $80^{\circ} \mathrm{C}$. A temperatura da célula também foi ajustada para $100^{\circ} \mathrm{C}$, sendo que o ânodo da célula foi alimentado com o 
$\mathrm{EG}+\mathrm{KOH}$ ambos na concentração de $2 \mathrm{~mol}^{\mathrm{L}} \mathrm{L}^{-1} \mathrm{com}$ um fluxo de aproximadamente $1 \mathrm{~mL} \cdot \mathrm{min}^{-1}$.

Para o estudo em célula a combustível unitária alimentada diretamente por EG 2 mol.L-1 e KOH 2 mol.L-1, foi utilizada a membrana Nafion® 117 (DuPont ${ }^{\mathrm{TM}}$ ) como eletrólito que foi tratada para ser utilizada em meio básico.

A camada difusora (GDL do inglês Gas Diffusion Layer) empregada na confecção de todos os MEAs foi o tecido de carbono (EC-CC1-060T), o qual é tratado com PTFE (35\%) fornecido pela ElectroChem Inc. A camada catalítica do cátodo foi preparada utilizando o catalisador comercial Pt/C ETEK (20\% de Pt em massa, lote: C0740621) com $1 \mathrm{mg}_{\mathrm{pt}} \cdot \mathrm{cm}^{-2}$ e $30 \%$ de Nafion ${ }^{\circledR}$, já para a preparação da camada catalítica do ânodo foi utilizado $1 \mathrm{mg}_{\mathrm{pt}} \cdot \mathrm{cm}^{-2}$ dos catalisadores eletroquímicos Pt/C, Pd/C, PtSn/C, PdSn/C, PtPd/C com $30 \%$ de Nafion $\AA$ (dispersão 5\% DE520 da DuPont ${ }^{\mathrm{TM}}$ ).

\subsubsection{Preparação de MEA}

Os MEAs foram preparados pela técnica de pintura por pincel. Neste processo, as camadas catalíticas anódica e catódica foram preparadas utilizando o catalisador eletroquímico a ser estudado misturando uma solução de Nafion ${ }^{\circledR} \mathrm{e}$ álcool isopropílico. Após agitação em ultrassom, a mistura é aplicada sobre um tecido de carbono (previamente seco por uma lâmpada) e colocado em uma estufa para secar a uma temperatura de $70{ }^{\circ} \mathrm{C}$ por $2 \mathrm{hrs}$. Em seguida, para a formação do MEA, os dois eletrodos preparados são prensados junto com a membrana de Nafion ${ }^{\circledR}$ a $125^{\circ} \mathrm{C}$ a uma pressão de $225 \mathrm{kgf.cm}^{-2}$ por 3 minutos. A área do MEA é de $5 \mathrm{~cm}^{2}$.

\subsection{Tratamento da membrana para utilização em meio alcalino}

Uma célula a combustível ácida (como a PEMFC) apresenta como eletrólito polimérico sólido a membrana de Náfion ${ }^{\circledR}$. 
O Náfion ${ }^{\circledR}$ é um copolímero politetrafluoretileno (PTFE), desenvolvido pela Dupont em 1962 ${ }^{[63,64]}$. Este material atua como uma barreira de gases e elétrons (isolante eletrônico), possui resistência mecânica, possui estabilidade química e eletroquímica sob condições de operação, possui alta condutividade de prótons para fornecer altas correntes com o mínimo de perdas resistivas, etc.

Estudos relataram a possibilidade do uso de membranas poliméricas aniônicas e membranas poliméricas modificadas com $\mathrm{KOH}$ que são aplicadas em células a combustível alcalinas alimentadas diretamente por álcool (ADAFCs). Essas membranas aniônicas apresentam as seguintes vantagens:

$\checkmark$ Baixa permeabilidade do álcool (redução do efeito crossover) devido à densa estrutura da membrana e dos anions $\mathrm{OH}^{-}$serem transportados do cátodo para o ânodo[65-68];

$\checkmark$ A água produzida no ânodo é consumida no cátodo o que facilita 0 gerenciamento de água na célula[65].

O tratamento químico das membranas de Náfion ${ }^{\circledR}$ para aplicação em célula a combustível unitária consiste em cortar as membranas nas dimensões de $10 \mathrm{~cm} \times$

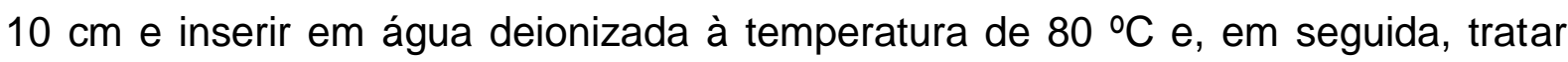
com soluções de $\mathrm{H}_{2} \mathrm{O}_{2}(3 \%)$ e $\mathrm{H}_{2} \mathrm{SO}_{4}(1$ mol.L-1 $)$ a $80 \stackrel{\circ}{\circ} \mathrm{C}$, para remoção de eventuais resíduos orgânicas e minerais. Após a remoção de impurezas foram tratadas com $\mathrm{KOH}(6,0$ mol.L-1) a temperatura ambiente por 19 horas. Entre cada tratamento as membranas foram imersas em água deionizada. Cada etapa do processo de imersão em $\mathrm{H}_{2} \mathrm{O}_{2}$ e $\mathrm{KOH}$ foi de 1 e 19 horas respectivamente e, ao final, as membranas foram lavadas com água deionizada por mais três vezes ${ }^{[7]}$. 


\section{RESULTADOS E DISCUSSÃO}

Os catalisadores eletroquímicos de $\mathrm{Pt} / \mathrm{C}, \mathrm{Pd} / \mathrm{C}$ e $\mathrm{Sn} / \mathrm{C}$ e os $\mathrm{PtSn} / \mathrm{C}, \mathrm{PdSn} / \mathrm{C}$ e PtPd/C, nas proporções atômicas de 90:10, 70:30 e 50:50 foram preparados pelo processo de redução por borohidreto de sódio ${ }^{[37,38,69]}$ usando sais de Pt, Pd e Sn, como fontes de metais (item 4.1).

\subsection{Caracterização e aplicação dos catalisadores eletroquímicos em AFC}

\subsubsection{Catalisador PtSn/C}

A FIG. 6 mostra os difratogramas de raios- $X$ para os catalisadores eletroquímicos de $\mathrm{Pt} / \mathrm{C}, \mathrm{PtSn} / \mathrm{C}$ e $\mathrm{Sn} / \mathrm{C}$ preparados pelo método da redução por borohidreto.

Os quatro picos de difração observados em, aproximadamente $2 \theta=40^{\circ}, 47^{\circ}$, $68^{\circ}$ e $82^{\circ}$ estão associados, respectivamente, aos planos (111), (200), (220) e (311) da estrutura cúbica de face centrada (cfc) da platina e suas ligas.

Os difratogramas indicam que todos os materiais apresentaram a mesma estrutura da platina, cúbica de face centrada (CFC), sem uma significativa mudança nas posições dos picos associado ao plano (220) da fase da platina ${ }^{[70,71]}$. O parâmetro de rede de materiais à base de Pt é de 0,392 nm [70-72]. Observa-se que a inserção de Sn na síntese dos catalisadores eletroquímicos não alterou o parâmetro de rede (TAB. 3) $)^{[7,31]}$. Tal comportamento pode ser comprovado pela simples observação da posição dos picos nos difratogramas de raios-X. Em relação ao catalisador eletroquímico de Sn pode ocorrer a formação de óxidos de estanho que devido à sua estrutura amorfa não é detectado nos difratogramas. 


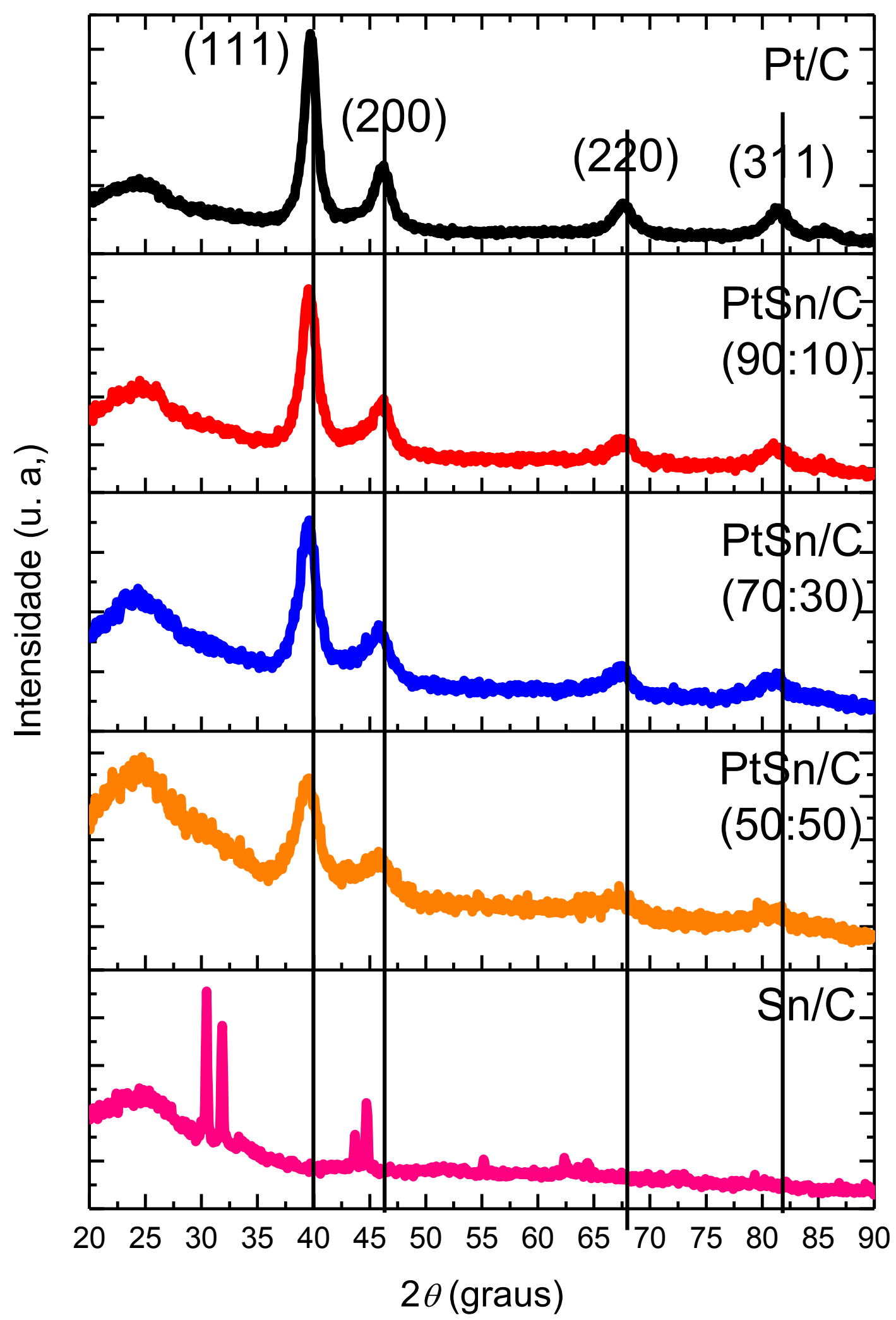

FIGURA 6 - Difratogramas dos catalisadores eletroquímicos Pt/C, PtSn/C e do Sn/C suportados em carbono. 
Os catalisadores eletroquímicos foram caracterizados por EDX para obtenção de suas razões molares e para a certificação da composição dos mesmos. A TAB. 3 mostra os resultados do tamanho médio de cristalito, os parâmetros de rede obtidos pelos difratogramas de DRX e a composição dos catalisadores em mol obtidos por EDX. Para todos os catalisadores eletroquímicos sintetizados à base Pt e Sn sobre substrato de carbono, os valores das razões molares obtidas por EDX foram próximos aos valores nominais, confirmando que o método por borohidreto é eficiente para produção dos catalisadores propostos.

TABELA 3 - Tamanho médio de cristalito, parâmetro de rede e composição em $\%$ mol por EDX para catalisadores eletroquímicos à base Pt e Sn sobre substrato de carbono.

\begin{tabular}{lccc}
\hline $\begin{array}{c}\text { Catalisadores } \\
\text { Eletroquímicos }\end{array}$ & $\begin{array}{c}\text { Tamanho médio } \\
\text { de cristalito } \\
(\mathbf{n m})\end{array}$ & $\begin{array}{c}\text { Parâmetro de } \\
\text { rede } \\
(\mathbf{n m})\end{array}$ & $\begin{array}{c}\text { Composição EDX } \\
\text { Pt:Sn } \\
(\% \text { mol) }\end{array}$ \\
\hline $\mathrm{Pt} / \mathrm{C}$ & 5 & 0.392 & $100: 0$ \\
$\mathrm{PtSn} / \mathrm{C} \mathrm{(90:10)}$ & 4 & 0.392 & $86: 14$ \\
$\mathrm{PtSn} / \mathrm{C} \mathrm{(70:30)}$ & 4 & 0.392 & $69: 31$ \\
$\mathrm{PtSn} / \mathrm{C} \mathrm{(50:50)}$ & 4 & 0.393 & $51: 49$ \\
$\mathrm{Sn} / \mathrm{C}$ & ----- & ----- & $100: 0$ \\
\hline
\end{tabular}

As imagens por MET foram realizadas para avaliar a distribuição e o tamanho médio das partículas dos catalisadores de Pt/C, PtSn/C (90:10), PtSn/C (70:30), $\mathrm{PtSn} / \mathrm{C}$ (50:50) e Sn/C. No catalisador Pt/C, as nanopartículas de platina dispersas no suporte de carbono exibiram um tamanho médio de partícula de $5 \mathrm{~nm}$ (FIG.7a), enquanto que para o catalisador eletroquímico de $\mathrm{Sn} / \mathrm{C}$ não foi possível estimar o tamanho médio das partículas devido ao grande número de aglomerados formados, que dificultam a visualização do contorno das partículas para contagem (FIG. 7b). 
a)

b)
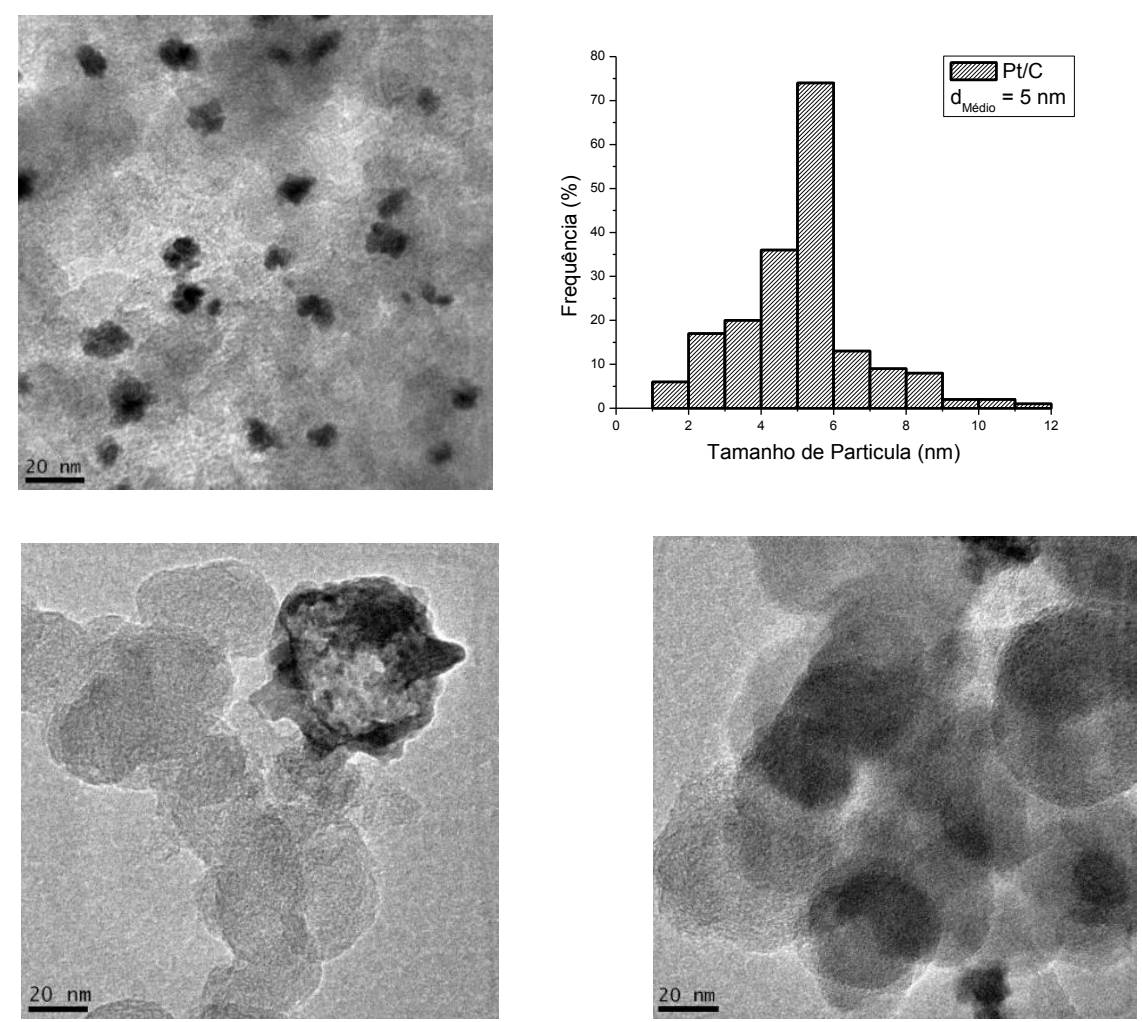

FIGURA 7 - Micrografias obtidas por microscopia eletrônica de transmissão e distribuição dos tamanhos de partícula dos catalisadores eletroquímicos preparados pelo método do borohidreto: (a) Pt/C, (b) $\mathrm{Sn} / \mathrm{C}$.

As imagens por MET para os catalisadores eletroquímicos PtSn/C (90:10), $\mathrm{PtSn} / \mathrm{C}(70: 30)$ e PtSn/C (50:50) exibiram um tamanho médio de partícula de $4 \mathrm{~nm}$ (FIG. 8), indicando que o aumento da quantidade de estanho na composição do catalisador eletroquímico não leva ao aumento no tamanho médio de partícula, de acordo com a literatura[7]. O tamanho médio de partícula tem um papel importante nas reações de oxidação do combustível EG, ou seja, sua diminuição leva a um aumento do número de defeitos na estrutura cristalina do catalisador e, por consequência, uma maior densidade de potência.

Os resultados obtidos por MET mostram que as nanopartículas de Pt estão distribuídas de forma homogênea nos suportes de carbono, no entanto também há presença de alguns aglomerados de partículas, principalmente para o catalisador $\mathrm{PtSn} / \mathrm{C}$ - 70:30. As áreas mais claras que aparecem principalmente na periferia das imagens são denominadas regiões semitransparentes segundo a literatura [73,74] 
representam os agregados das partículas de carbon black e de óxido de estanho. As esferas escuras são as partículas de platina, cujos diâmetros médios variaram de 2 a $5 \mathrm{~nm}$.

a)

b)
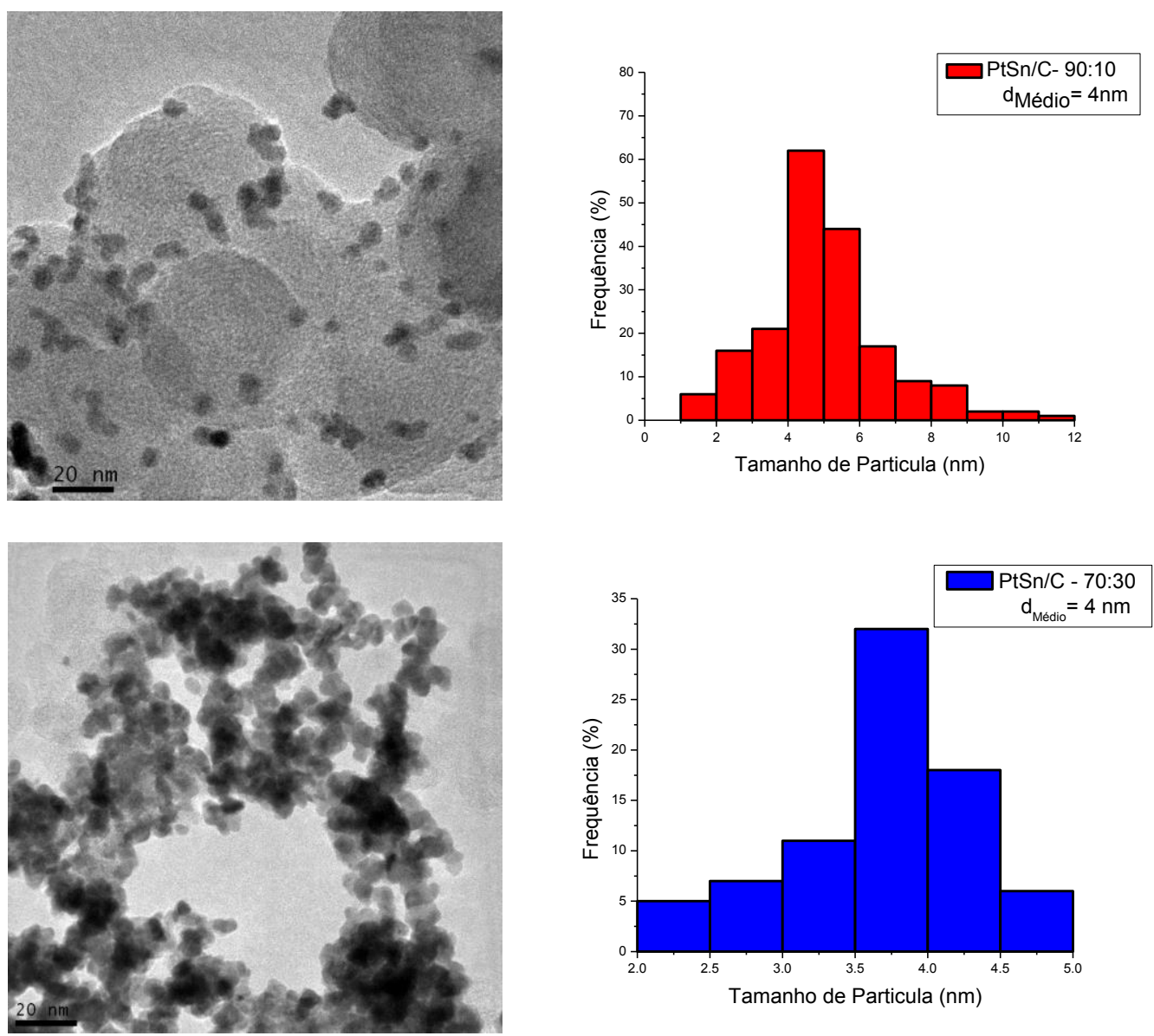

c)
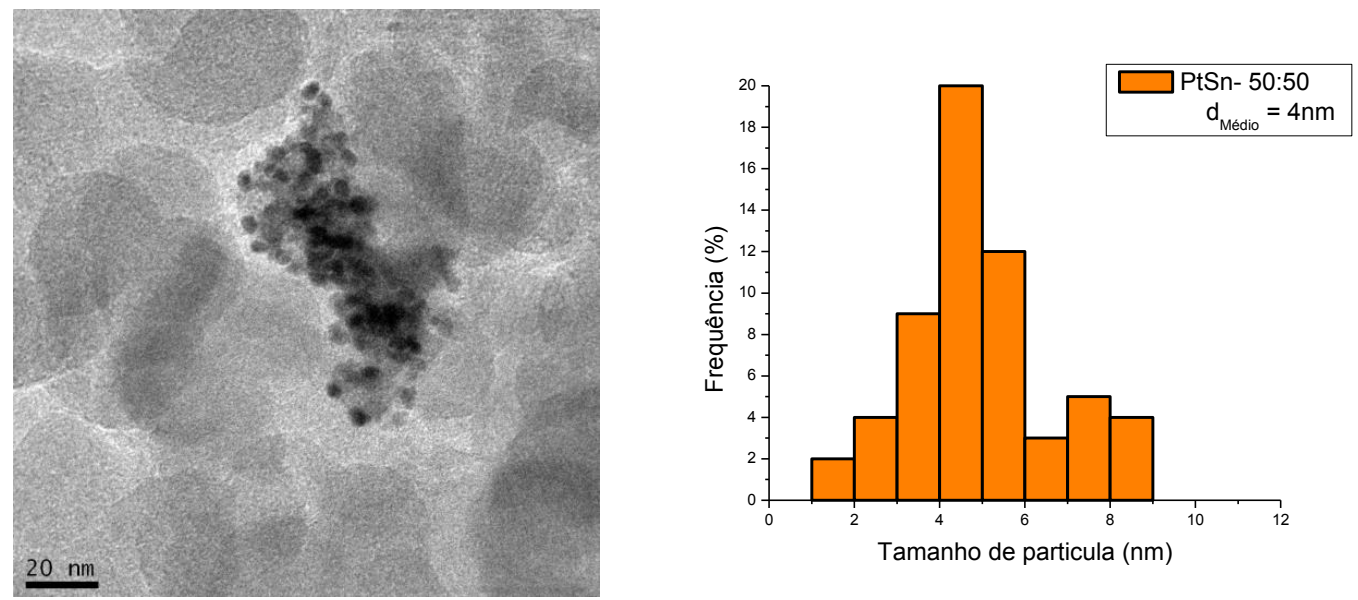

FIGURA 8 - Micrografias obtidas por MET e distribuição dos tamanhos de partícula dos catalisadores eletroquímicos preparados pelo método do borohidreto: a) PtSn/C (90:10), b) PtSn/C (70:30) e c)PtSn/C (50:50). 
Os voltamogramas cíclicos dos catalisadores eletroquímicos de Pt/C, PtSn/C (90:10), PtSn/C (70:30) e PtSn/C (50:50) preparados pelo método do borohidreto, na ausência de álcool, estão apresentados na FIG. 9. A escolha destas três proporções de PtSn para os catalisadores eletroquímicos binários foram feitas para estudar como cada composição se comporta em relação a oxidação do EG (FIG. 10) e qual delas apresentam o melhor resultado.

Nos experimentos a unidade de corrente (I) foi normalizada por grama de platina $\left(m A \cdot m g_{\mathrm{t}}^{-1}\right)$. As curvas voltamétricas em meio alcalino foram obtidas na presença do eletrólito $\mathrm{KOH}, 1,0 \mathrm{~mol}$. $\mathrm{L}^{-1}$, e registrado no intervalo de $-0,85 \mathrm{~V}$ a $0,2 \mathrm{~V}$ vs. $\mathrm{Ag} / \mathrm{AgCl}(\mathrm{E}=-0,9 \vee$ vs. $\mathrm{ERH})$.

Nos voltamogramas cíclicos correspondentes aos catalisadores eletroquímicos em meio alcalino há três regiões anodicas. Os picos na região I correspondem à adsorção e dessorção de hidrogênio, chamada região do hidrogênio. Observa-se na região I que os picos para os catalisadores $\mathrm{PtSn} / \mathrm{C}$ foram suprimidos em relação ao $\mathrm{Pt} / \mathrm{C}$. Isso indica que a forte adsorção de $\mathrm{H}_{2}$ na superfície do catalisador foi enfraquecida, ou seja, este comportamento pode estar relacionado ao fato dos átomos de estanho recobrirem os sítios de platina, assim impedindo a adsorção de hidrogênio. Este tipo de comportamento é comumente observado na literatura para a platina combinada com um segundo metal, tais como $\mathrm{Sn}$, Rh ou $A u^{[74-76]}$. Para os catalisadores $\mathrm{PtSn} / \mathrm{C}$, os picos voltamétricos na região de $-0,8$ a $0,5 \mathrm{~V}(\mathrm{vs}$. $\mathrm{Ag} / \mathrm{AgCl})$ são devidos à somatória de processos de absorção e adsorção de hidrogênio.

A região II dos VC corresponde à região da dupla camada elétrica (região que apresenta apenas corrente capacitiva). Nesta região ocorrem processos de oxidação superficial do eletrodo relacionados à adsorção de espécies $\mathrm{OH}^{-}$formados pela oxidação da água. Na região III (potenciais mais positivos) ocorre a formação de óxidos metálicos (hidratados).

Nos voltamogramas cíclicos dos catalisadores eletroquímicos PtSn/C (90:10) e PtSn/C (70:30) também foi observado um aumento da corrente de pico de redução de óxidos quando consideramos a varredura catódica em comparação ao catalisador de $\mathrm{Pt} / \mathrm{C}$, comportamento este associado aos seguintes fatores: o efeito 
eletrônico, ao mecanismo bifuncional e a presença de Sn, ou seja, para estes catalisadores binários há formação de uma maior quantidade de espécies oxigenadas que poderia facilitar a oxidação eletroquímica do EG em meio básico.

Pelos perfis voltamétricos observa-se que os catalisadores $\mathrm{PtSn} / \mathrm{C}$ apresentam picos de oxidação para valores menores do que o potencial para oxidação da Pt/C. Portanto, a formação de óxidos para catalisadores PtSn/C ocorrerá em menores potenciais. Desta forma, os intermediários como CO será oxidado em potenciais menores em relação ao catalisador Pt/C.

Por meio desses resultados pode-se observar para o catalisador $\mathrm{PtSn} / \mathrm{C}$ (70:30) um pico na região da dupla camada elétrica (região II), relacionado a adsorção de espécies $\mathrm{OH}^{-}$. Isso significa que sobre a superfície da PtSn/ (70:30) ocorreu a adsorção de espécies $\mathrm{OH}^{-}$, e, desta forma, a produção de óxidos pode favorecer o processo de oxidação de intermediários resultante da oxidação do EG.

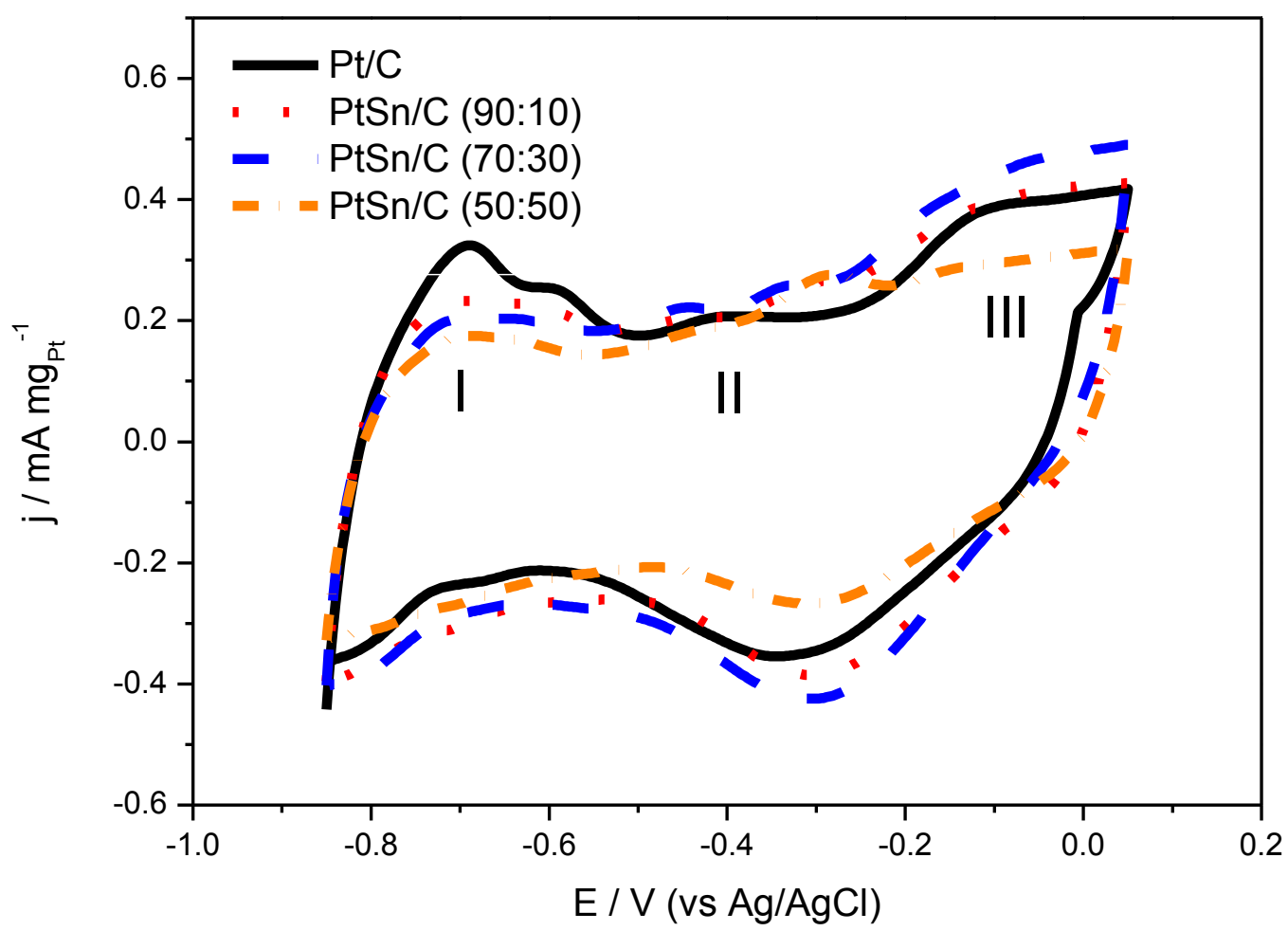

FIGURA 9 - Voltametria cíclica de Pt/C e PtSn/C em solução $\mathrm{KOH} 1 \mathrm{~mol} . \mathrm{L}^{-1} \mathrm{com}$ velocidade de varredura de $10 \mathrm{mV} \cdot \mathrm{s}^{-1}$ (ausência de álcool). 
Na FIG. 10a é mostrada a curva de voltametria de varredura linear dos

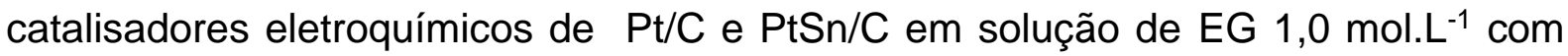
$\mathrm{KOH}$ 1,0 mol. $\mathrm{L}^{-1}$ saturado com $\mathrm{N}_{2}$ com velocidade de varredura de $10 \mathrm{mV} . \mathrm{s}^{-1}$. Com este experimento é possível ver que os potenciais da reação de oxidação do etileno glicol esta muito próximo de $-0,68 \mathrm{~V}(\mathrm{vs}$. $\mathrm{Ag} / \mathrm{AgCl})$, exceto para $\mathrm{PtSn} / \mathrm{C}(50: 50)$ que se deslocou para $-0,70 \mathrm{~V}(\mathrm{vs}$. $\mathrm{Ag} / \mathrm{AgCl})$ mostrando-se mais positivo do que os outros materiais e consequentemente menos ativo. Dentre todos os materiais estudados por voltametria cíclica o catalisador eletroquímico de PtSn/C (70:30) foi o mais ativo em toda a faixa de potencial estudada indicando ser um candidato promissor para os testes em célula a combustível alimentadas diretamente por etileno glicol.

A estabilidade dos materiais PtSn/C foram avaliadas usando experimentos de cronoamperometria, FIG. 10b. As curvas de cronoamperometria dos catalisadores eletroquímicos de $\mathrm{PtSn} / \mathrm{C}$ e $\mathrm{Pt} / \mathrm{C}$ foram realizadas em etileno glicol $1 \mathrm{~mol}^{-\mathrm{L}^{-1} \mathrm{em}}$ $\mathrm{KOH} 1 \mathrm{~mol} . \mathrm{L}^{-1}$ a um potencial fixo de $-0,35 \mathrm{~V}(\mathrm{vs}$. $\mathrm{Ag} / \mathrm{AgCl})$. Nos primeiros segundos, os catalisadores eletroquímicos mostraram grandes decrescimos e após 3 minutos todos os materiais atingiram uma corrente razoavelmente estável até chegar ao fim dos 30 minutos de experimeto. Neste período de tempo as medidas da densidade da corrente foram 1,46 mA.mg part $_{\mathrm{t}}^{-1}$ para $/ \mathrm{C}, 1,72 \mathrm{~mA} \cdot \mathrm{mg}_{\mathrm{pt}}^{-1}$ para PtSn/C (90:10), 1,92 mA.mg pt $_{t}^{-1}$ para PtSn/C (70:30), e 1,30 mA.mg-1 para PtSn/C (50:50). Os estudos com a técnica de cronoamperometria confirmaram que o catalisador eletroquímico de PtSn/C (70:30) foram mais ativo para a oxidação do EG, ou seja, o mesmo se mantém ativo quando submetidos a maiores tempo de operação são exigidos em um determinado potencial.

O melhor desempenho eletroquímico de $\mathrm{PtSn} / \mathrm{C}$ (70:30) poderia ser devido ao efeito sinérgico entre a facilita a oxidação do álcool por meio de espécies contendo oxigênio adsorvido em átomos de $\mathrm{Sn}^{[31,37]}$, mas o mecanismo bifuncional e eletrônico não pode ser descartado. O PtSn/C (50:50) apresentou menor atividade em relação aos outros catalisadores provavelmente este fato está relacionada a uma composição otima de estanho de $30 \%$ na composição de catalisadores eletroquímicos binários. 

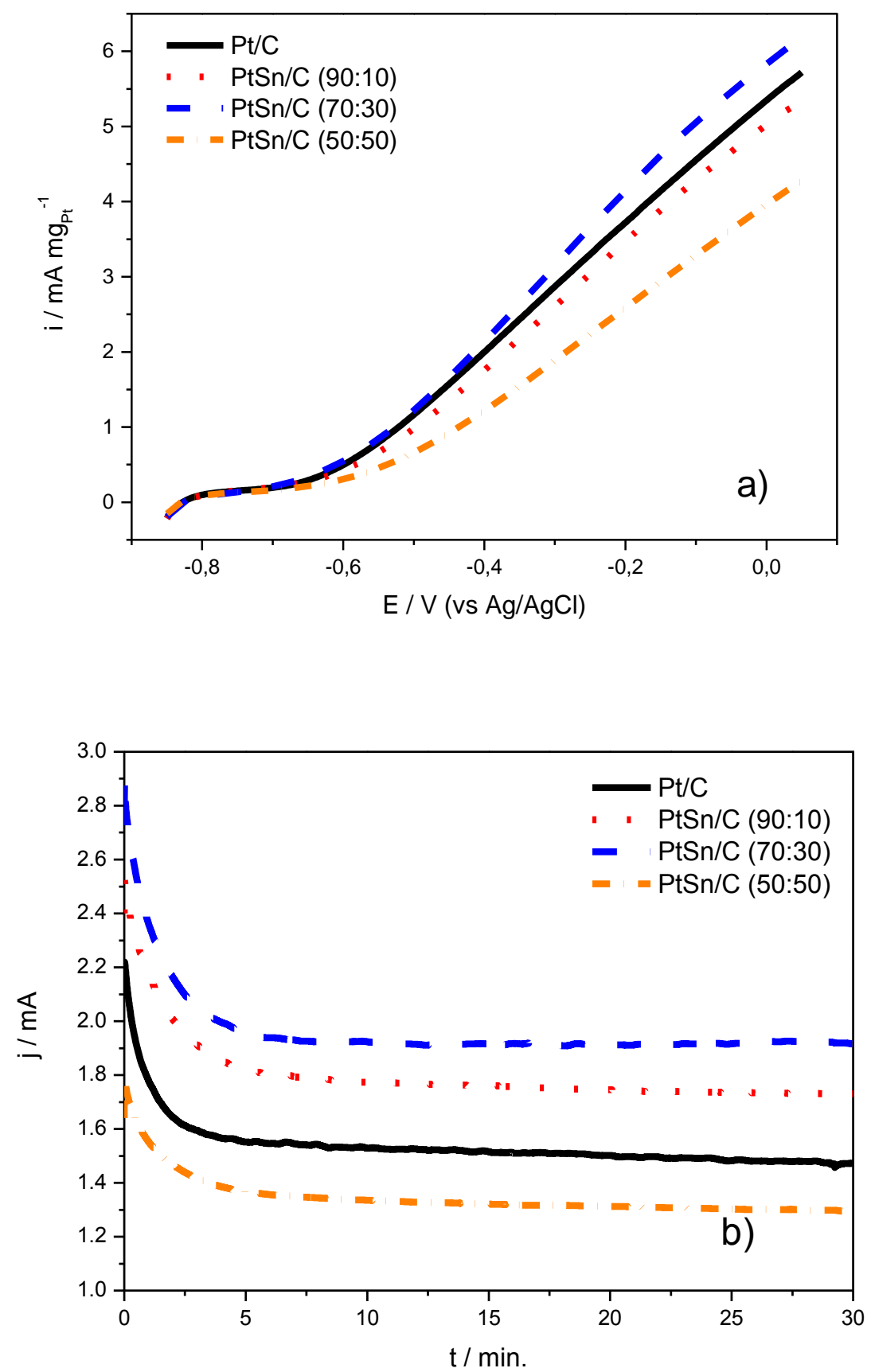

FIGURA 10 - a) Voltamogramas Cíclicos para os catalisadores eletroquímicos de $\mathrm{Pt} / \mathrm{C}$ e $\mathrm{PtSn} / \mathrm{C}$ em solução de EG 1 mol.L-1 e de $\mathrm{KOH} 1 \mathrm{~mol} . \mathrm{L}^{-1} \mathrm{com}$ velocidade de varredura de $10 \mathrm{mV} . \mathrm{s}^{-1}$, b) Curvas de Cronoamperometrias em 1,0 mol.L-1 de etileno glicol em solução de $1,0 \mathrm{~mol} . \mathrm{L}^{-1} \mathrm{KOH}$ para os catalisadores eletroquímicos $\mathrm{PtSn} / \mathrm{C}$ em diferentes composição preparados pelo método de borohidreto no potencial de $-0,35 \mathrm{~V}(\mathrm{vs}$. $\mathrm{Ag} / \mathrm{AgCl})$ à $25^{\circ} \mathrm{C}$. 
Os espectros de FTIR in situ (FIG. 11) foram realizados de modo a correlacionar a atividade de oxidação eletroquímica do EG com as principais vias de formação (FIG. 2). Os espectros de FTIR na região entre 3000 a $850 \mathrm{~cm}^{-1}$ foram registradas durante oxidação eletroquímica do etielno glicol para os catalisadores eletroquímicos Pt/C e PtSn/C em solução de 1 mol.L-1 de EG e 1 mol.L-1 de $\mathrm{KOH}$. Considerando as FTIR resultantes foi possível observar o aparecimento de bandas relacionadas com a formação de $\mathrm{CO}_{2}$ a $2343 \mathrm{~cm}^{-1}$, em $1072 \mathrm{~cm}^{-1}$ o estiramento de aldeídos (glioxal, glicolato, gliceraldeído), em $1240 \quad \mathrm{~cm}^{-1} \quad 0$ C-O de glicolato e a banda em em $1320 \mathrm{~cm}^{-1}$ atribuídos a glicerato e oxalato.

As alterações nas concentrações de espécies específicas produzidas durante a oxidação do EG (aumento ou diminuição) foram analisadas por funções lineares Lorentzianas $^{[77]}$. Assim, a intensidade e a largura da linha de cada banda puderam ser analisadas individualmente, conforme mostra o gráfico de intensidade integrada das bandas de estiramento do aldeído (glioxal, glicolato, gliceraldeído) ${ }^{[59,83]}$, estiramento de oxalato[59,78], glicerato e oxalato ${ }^{[59,78]}$.

Na FIG. 12 são apresentadas as intensidades integradas das bandas de estiramento do aldeído $\left(1072 \mathrm{~cm}^{-1}\right)$ e é possível notar que a adição de Sn inibe o processo de formação de aldeído, sugerindo que para o catalisador eletroquímico $\mathrm{PtSn} / \mathrm{C}(70: 30)$ a produção destas espécies aumenta em sobrepotenciais positivos.

Alguns autores sugerem que glicerato e oxalato são os principais produtos de oxidação do EG sobre catalisadores eletroquímicos à base de $\mathrm{Pt}^{[51,78]}$, e para estes produtos são atribuídas a banda em $1320 \mathrm{~cm}^{-1[59,78]}$ (FIG. 13a). Observa-se que, com a diminuição da quantidade de Pt nos catalisadores, o aparecimento de grupos carboxílicos no potencial de produção é deslocado para potenciais mais positivos, e sua intensidade diminui. No entanto observa-se na banda $1240 \mathrm{~cm}^{-1}$ (FIG. 13b) que o produto mais oxidado sem as quebras do C-C corresponde ao estiramento $\mathrm{O}-\mathrm{H}$ do oxalato, observa-se que para o catalisador $\mathrm{PtSn} / \mathrm{C}$ (70:30) a banda de intensidade integrada é superior aos outros catalisadores eletroquímicos. Esta pode ser uma possível explicação para a atividade eletroquímica mais elevada, no entanto este resultado também é um indício de que a reação de oxidação do EG em catalisadores eletroquímicos de PtSn se processa de modo incompleto. 


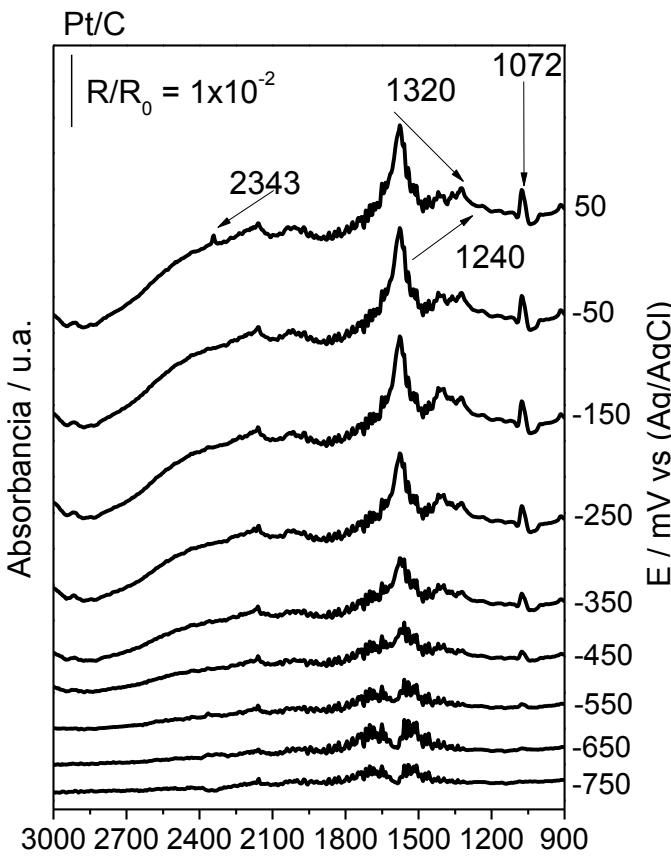

Numero de Onda $/ \mathrm{cm}^{-1}$
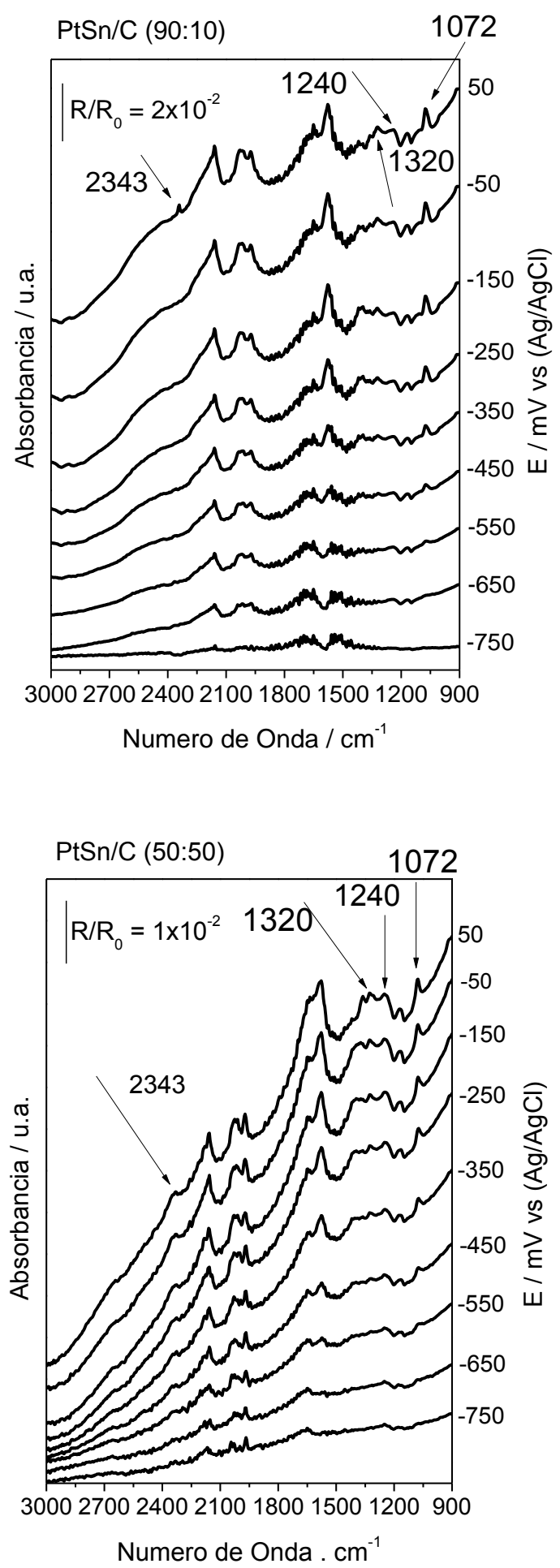

FIGURA 11 - Espectros de absorção ATR-FTIR in situ coletados no intervalo de potenciais de $-0,8$ a $0,1 \mathrm{~V}$ ( $v s$. $\mathrm{Ag} / \mathrm{AgCl}$ ), em solução aquosa de $1 \mathrm{~mol} . \mathrm{L}^{-1}$ de etileno glicol e 1,0 mol.L-1 de $\mathrm{KOH}$ para os catalisadores eletroquímicos de $\mathrm{Pt} / \mathrm{C}$ e $\mathrm{PtSn} / \mathrm{C}$. Os backgrounds foram coletados em $-0.85 \mathrm{~V}$ (vs. $\mathrm{Ag} / \mathrm{AgCl})$, a uma velocidade de varredura de $1 \mathrm{mV} . \mathrm{s}^{-1}$. 


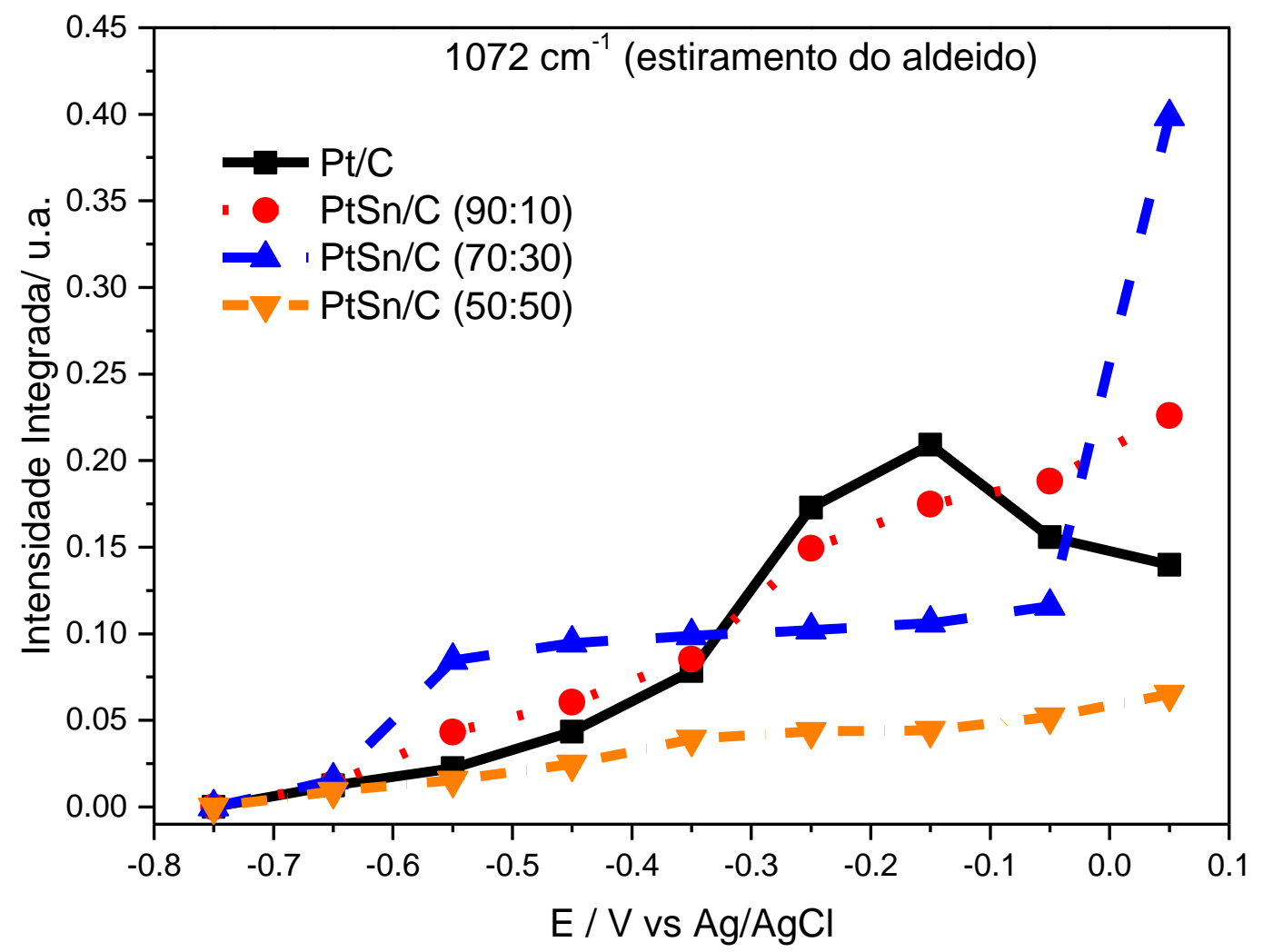

FIGURA 12 - Intensidade Integrada das bandas do aldeído $\left(1072 \mathrm{~cm}^{-1}\right)$ em função do potencial para os catalisadores eletroquímicos $\mathrm{Pt} / \mathrm{C}, \mathrm{PtSn} / \mathrm{C}$. Os "backgrounds" foram coletados em $-0.85 \mathrm{~V}$ (vs. Ag/AgCl), a uma velocidade de varredura de $1 \mathrm{mV} \cdot \mathrm{s}^{-1}$. 

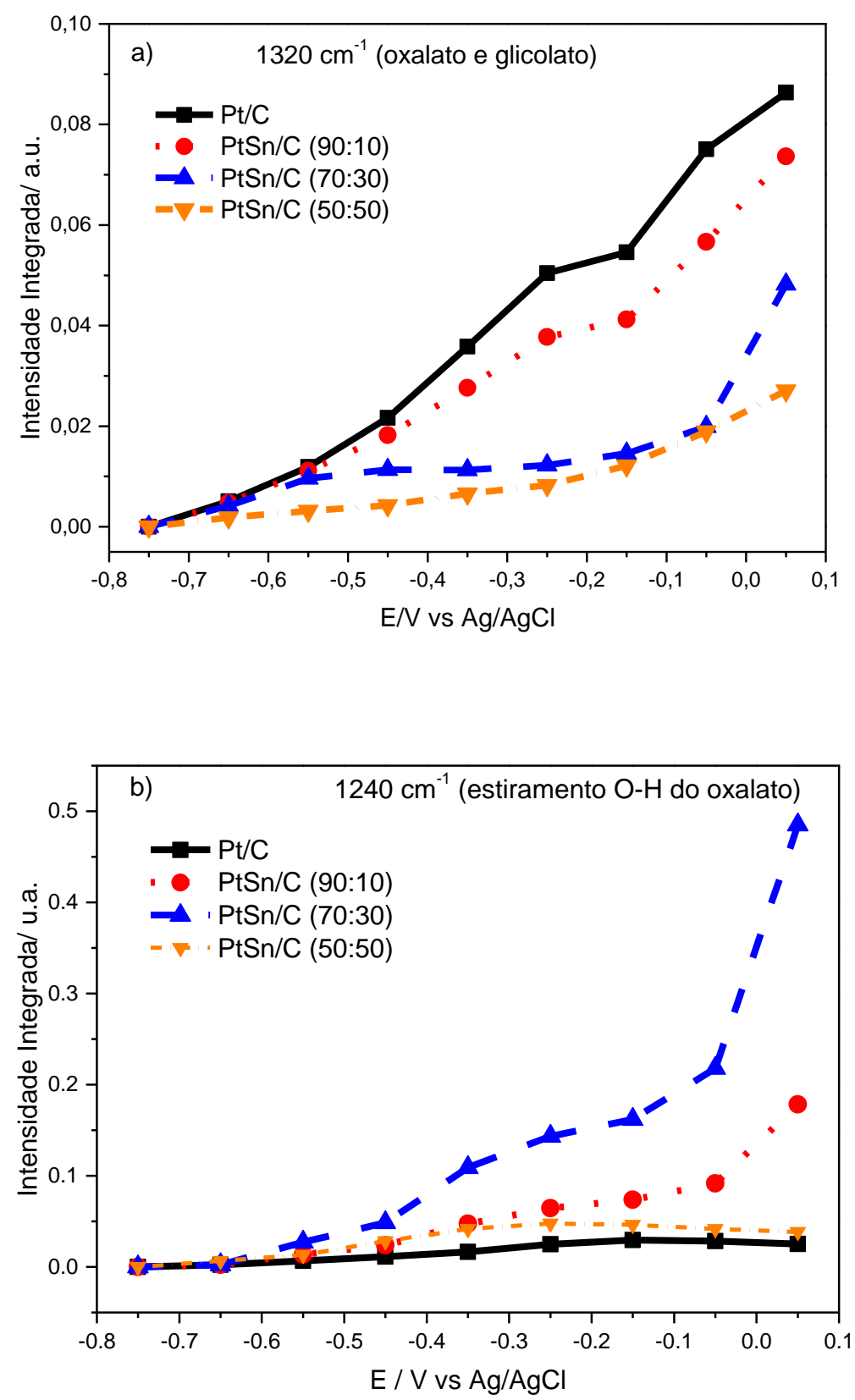

FIGURA 13 - Intensidade Integrada das bandas em função do potencial para os catalisadores eletroquímicos $\mathrm{Pt} / \mathrm{C}$ e $\mathrm{PtSn} / \mathrm{C}$ a) oxalato e glicolato, b) estiramento $\mathrm{O}-\mathrm{H}$ do oxalato.

De acordo com os resultados, a oxidação do EG ocorre pelo mecanismo indireto e segundo Lima ${ }^{[78]}$ a adsorção dissociativa do EG produz monóxido de carbono adsorvido, e este intermediário é oxidado à $\mathrm{CO}_{2}$. 
Em nosso trabalho a produção de $\mathrm{CO}_{2}$ ocorreu apenas em potenciais mais positivos, -0,05V (FIG. 14), neste estudo também verifica-se ausência de sinal de carbonato $\left(1.400 \mathrm{~cm}^{-1}\right)$. Este fato pode indicar que os principais produtos de oxidação do EG sobre $\mathrm{PtSn} / \mathrm{C}$, são o glicolato e o oxalato ${ }^{[49,78]}$, de certa forma atestando que esta reação ocorre de forma incompleta sem aproveitamento total do número de elétrons. A formação de carbonato està associada à presença de $\mathrm{CO}_{2}$ do ambiente ou geração de $\mathrm{CO}_{2}$ como produto da oxidação do $\mathrm{EG}$. Tendo em vista que não foi observada a presença de $\mathrm{CO}_{2}$ no ambiente, pois há formação de $\mathrm{CO}_{2}$ somente em altos potenciais, é esperado que não se observe a formação de carbonato nos experimentos resultantes deste trabalho.

Em outro estudo para a oxidação do álcool em meio ácido, Silva et at. ${ }^{[79]}$ relataram que $\mathrm{SnO}_{2}$ facilita a clivagem da ligação $\mathrm{C}-\mathrm{C}$, no entanto, o óxido de estanho, perde esta característica em meio alcalino.

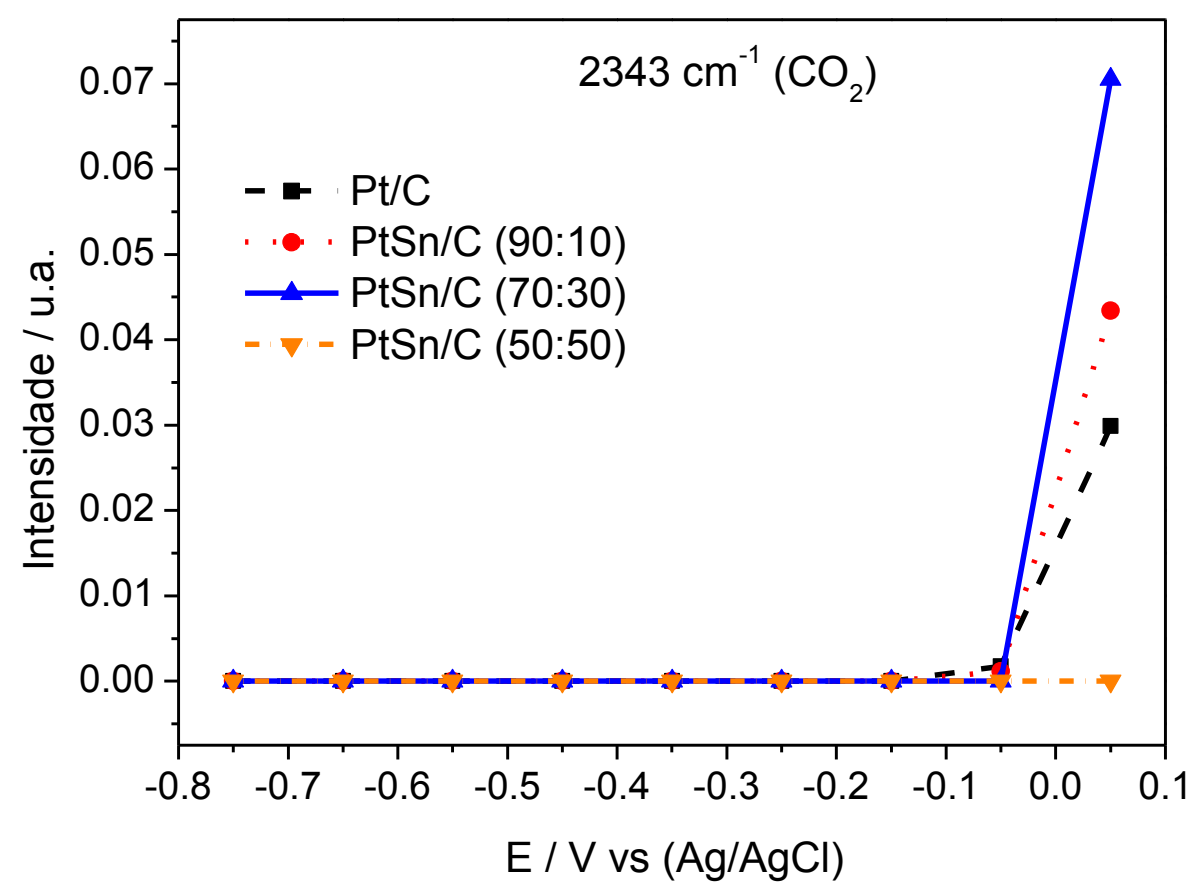

FIGURA 14 - Intensidade integrada das bandas de $\mathrm{CO}_{2}\left(2343 \mathrm{~cm}^{-1}\right)$ em função do potencial para os catalisadores eletroquímicos de $\mathrm{Pt} / \mathrm{C}$ e PtSn/C.

A FIG. 15 apresenta os desempenhos dos catalisadores eletroquímicos Pt/C, $\mathrm{PtSn} / \mathrm{C}$ em célula a combustível alcalina unitária alimentada diretamente por EG. 
Observa-se que o OCV (Open Circuit Voltage ou potencial de circuito aberto) para o catalisadores contendo $\mathrm{Sn}$ é maior do que o catalisador eletroquímico $\mathrm{Pt} / \mathrm{C}$, resultado que está de acordo com o observado nos experimentos de voltametria ciclica. As curvas de densidade de potência indicam que os catalisadores eletroquímicos contendo $S n$ são mais ativos para a reação de oxidação do $E G$, especialmente a composição PtSn/C - 70:30 (14,5 mW.cm-2), tendo uma medida de potência maior do que $\mathrm{Pt} / \mathrm{C}\left(\approx 10 \mathrm{~mW} \cdot \mathrm{cm}^{-2}\right)$, sendo esta uma ótima composição binária para oxidação do EG. Esta atividade está relacionada à atuação do mecanismo bifuncional, ou seja, espécies oxigenadas provenientes do estanho ou da solução eletrolítica, que auxiliam na oxidação dos intermediários fortemente adsorvidos, e do efeito eletrônico que provoca a formação de liga entre Pt e Sn e enfraquece a ligação entre os orbitais da platina com os intermediários fortamente adsorvidos, tais como a formação de oxalato, como observado por experiências in situ de ATR-FTIR o qual indica um maior aproveitamento eletrônico.

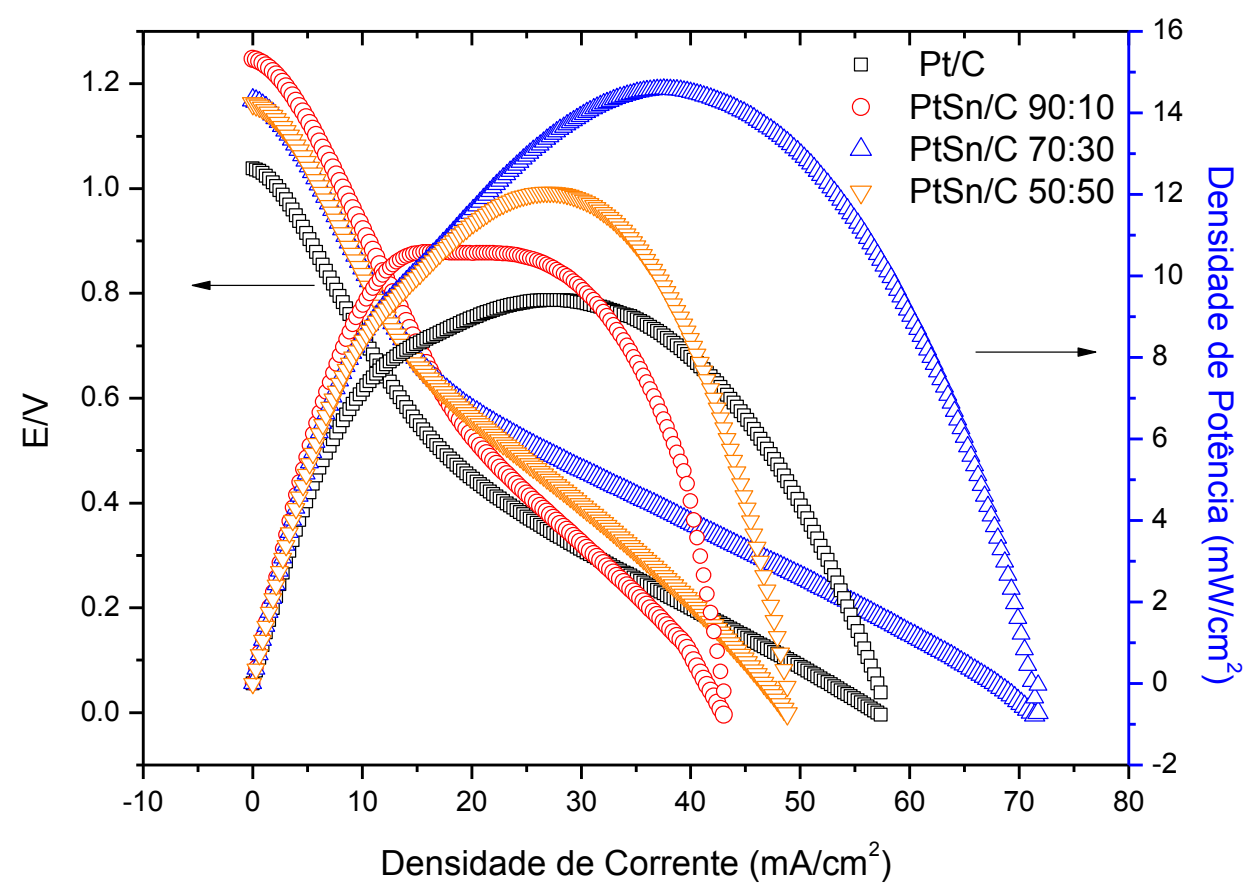

FIGURA 15 - Desempenho da célula a combustível em etileno glicol para os eletrocatalisadores $\mathrm{Pt} / \mathrm{C}$ e $\mathrm{PtSn} / \mathrm{C}$ a $100{ }^{\circ} \mathrm{C}$, preparados pelo método do borohidreto, membrana de Nafion 117 tratada com KOH, eletrólito de $E G+K O H\left(2 \mathrm{~mol}^{\circ} \mathrm{L}^{-1}\right)$, fluxo de $1 \mathrm{~mL} \cdot \mathrm{min}^{-1}$. 


\subsubsection{Catalisador PdSn/C}

A FIG. 16 mostra os difratogramas de raios $X$ para os catalisadores eletroquímicos de $\mathrm{Pd} / \mathrm{C}, \mathrm{PdSn} / \mathrm{C}$ e $\mathrm{Sn} / \mathrm{C}$ preparados pelo método da redução por borohidreto ${ }^{[7,25,70]}$.

Em todos os difratogramas de raios $X$ dos catalisadores pode ser visto, um pico largo em aproximadamente $2 \theta=25^{\circ}$, podendo variar de intensidade entre os catalisadores que corresponde ao plano (002) da estrutura hexagonal do carbono Vulcan XC72 do suporte.

Os quatro picos de difração observados em, aproximadamente $2 \theta=40^{\circ}, 46^{\circ}$, $68^{\circ}$ e $82^{\circ}$ estão associados com os planos cristalinos (111), (200), (220) e (311), respectivamente, os quais são caracteristicos da estrutura cúbica de face centrada (CFC) do paládio[25,80-83]. O parâmetro de rede de materiais à base de $\mathrm{Pd}$ é de 0,389 nm ${ }^{[2]}$. Observa-se que a inserção de $\mathrm{Sn}$ na síntese dos catalisadores eletroquímicos alterou o tamanho médio de cristalito (TAB. 4). Tal comportamento pode ser comprovado pela simples observação da posição dos picos nos difratogramas de raios X. Em relação ao catalisador eletroquímico de Sn pode ocorrer a formação de óxidos de estanho que devido a sua estrutura amorfa não é detectado nos difratogramas. Os padrões de DRX das amostras contendo Pd foram modelados por refinamento Pawley ${ }^{[82-84]}$ para o plano cristalino (220) (FIG. 16b). Verificou-se que os átomos de $\mathrm{Sn}$ alteraram a rede cristalina do $\mathrm{Pd}, \mathrm{a}=0,389 \mathrm{~nm}^{[83,85]}$. Os parâmetros de rede foram expandidos com o aumento da quantidade de Sn no catalisador, o que indica a formação de liga, um comportamento relatado na literatura quando se trata de materiais de $\mathrm{PdSn}{ }^{[25,80-85]}$. No entanto, não se pode assumir que todos os átomos de estanho foram incorporados à rede cristalina do paládio, como mostra a FiG. 16b , pois os picos de $\mathrm{SnO}_{2}$ podem ser de tamanho muito pequenos ou amorfos.

Neste caso, os difratogramas dos catalisadores $\mathrm{PdSn} / \mathrm{C}$ (50:50) não estão bem definidos, apresentando-se na fase amorfa (transformação de fase). 

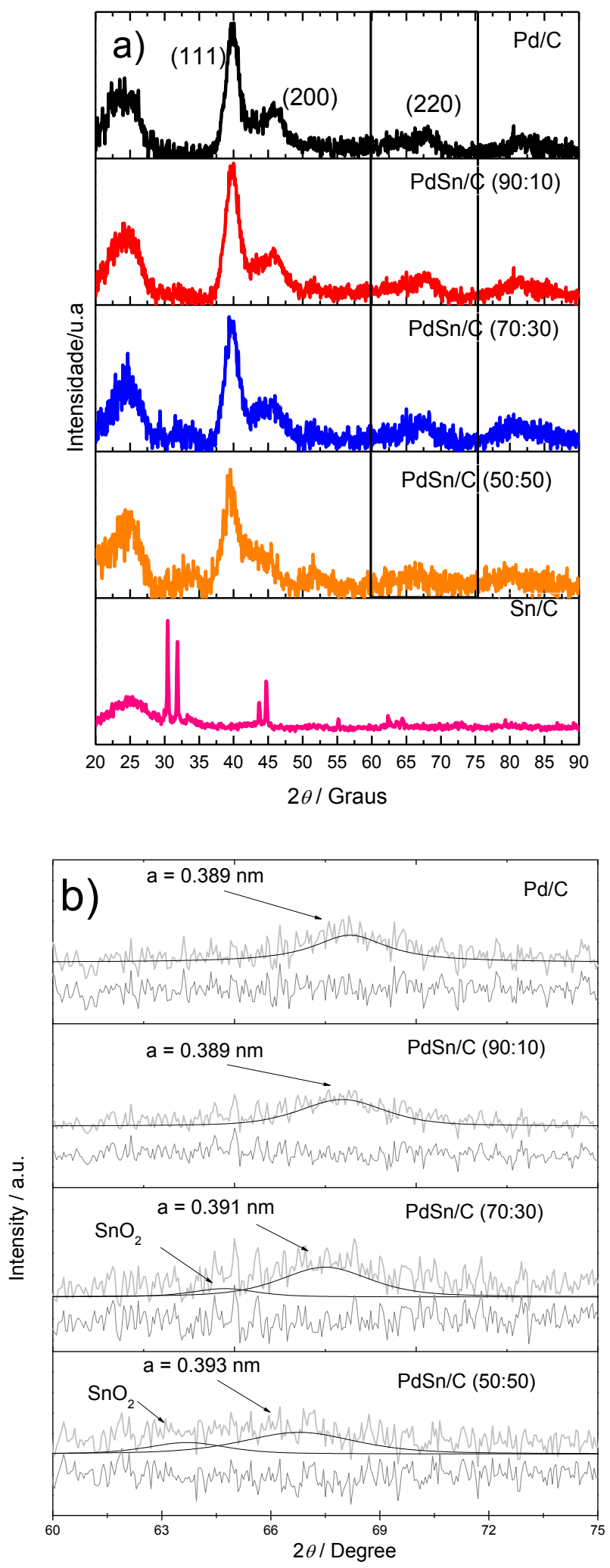

FIGURA 16 - a) Difratogramas dos catalisadores eletroquímicos $\mathrm{Pd} / \mathrm{C}, \mathrm{PdSn} / \mathrm{C}$ e do $\mathrm{Sn} / \mathrm{C}$ suportados em carbono b) Refinamento Pawley para o plano cristalino (220). 
Os catalisadores eletroquímicos foram caracterizados por EDX para obtenção de suas razões molares e para a certificação da composição. A TAB. 4 mostra os resultados do tamanho médio de cristalito, os parâmetros de rede obtidos pelos difratogramas de DRX e a composição dos catalisadores em \% mol obtidos por EDX. Para todos os catalisadores eletroquímicos sintetizados à base $\mathrm{Pd}$ e Sn sobre substrato de carbono, os valores das razões molares obtidas por EDX foram próximos aos valores nominais, confirmando que o método por borohidreto de sódio é eficiente para produção dos catalisadores propostos.

TABELA 4 - Tamanho médio de cristalito, parâmetro de rede e composição em \% mol por EDX para catalisadores eletroquímicos à base $\mathrm{Pd}$ e $\mathrm{Sn}$ sobre substrato de carbono.

\begin{tabular}{lccc}
\hline $\begin{array}{c}\text { Catalisador } \\
\text { Eletroquímico }\end{array}$ & $\begin{array}{c}\text { Tamanho médio } \\
\text { de cristalito } \\
(\mathbf{n m})\end{array}$ & $\begin{array}{c}\text { Parâmetro de } \\
\text { rede } \\
(\mathbf{n m})\end{array}$ & $\begin{array}{c}\text { Composição EDX } \\
\text { Pt:Sn } \\
(\% \text { mol) }\end{array}$ \\
\hline $\mathrm{Pd} / \mathrm{C}$ & 5 & 0.389 & $100: 0$ \\
$\mathrm{PdSn} / \mathrm{C}(90: 10)$ & 5 & 0.389 & $89: 11$ \\
$\mathrm{PdSn} / \mathrm{C}(70: 30)$ & 4 & 0.391 & $70: 30$ \\
$\mathrm{PdSn} / \mathrm{C}(50: 50)$ & ----- & 0.393 & $48: 52$ \\
$\mathrm{Sn} / \mathrm{C}$ & ----- & ---- & $100: 0$ \\
\hline
\end{tabular}

As imagens por MET foram realizadas para avaliar a distribuição e o tamanho médio das partículas dos catalisadores de Pd/C (100:0) e Sn/C (100:0). No catalisador de $\mathrm{Pd} / \mathrm{C}$, as nanopartículas de paládio dispersas no suporte de carbono exibiram um tamanho médio de partícula de $5 \mathrm{~nm}$ (FIG.17a), enquanto que para o catalisador eletroquímico Sn/C não foi possível estimar o tamanho médio das partículas devido ao grande número de aglomerados formados, estes aglomerados dificultam a visualização do contorno das partículas para contagem (FIG. 17b). 
a)

b)
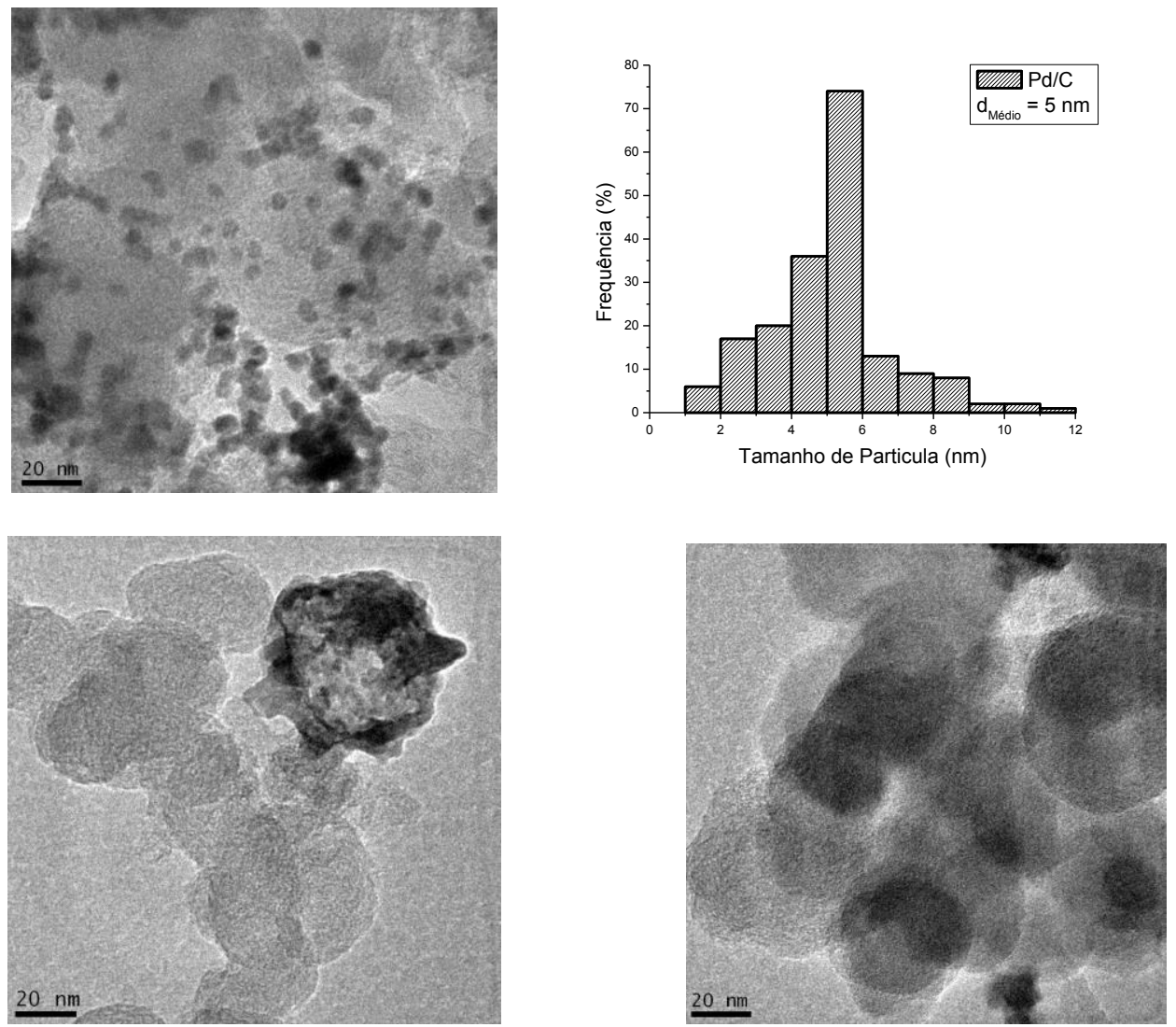

FIGURA 17 - Micrografias obtidas por microscopia eletrônica de transmissão e distribuição dos tamanhos de partícula dos catalisadores eletroquímicos preparados pelo método do borohidreto: (a) $\mathrm{Pd} / \mathrm{C}$, (b) $\mathrm{Sn} / \mathrm{C}$.

Na FIG. 18 são apresentas as imagens por MET para os catalisadores eletroquímicos PdSn/C (90:10); (70:30); (50:50). Os catalisadores PdSn/C (90:10) e $\mathrm{PdSn} / \mathrm{C}$ (70:30) exibiram um tamanho médio de partícula de 5 e $4 \mathrm{~nm}$ respectivamente, enquanto que para o catalisador $\mathrm{PdSn} / \mathrm{C}(50: 50)$ não há como estimar o tamanho médio das partículas pois o $\mathrm{Sn}$ encobre as partículas do $\mathrm{Pd}$, impossibilitando a visualização definida dessas partículas.

Os resultados obtidos por MET mostram que as nanopartículas de Pd estão distribuídas de forma homogênea nos suportes de carbono, no entanto há, também, presença de alguns aglomerados de partículas. As áreas mais claras que aparecem principalmente na periferia das imagens são denominadas regiões semitransparentes, segundo a literatura ${ }^{[7,25]}$, que representam os agregados das 
partículas de carbon black e de óxido de estanho. As esferas escuras são as partículas de paládio, cujos diâmetros médios variaram de 2 a $5 \mathrm{~nm}$.

a)

b)
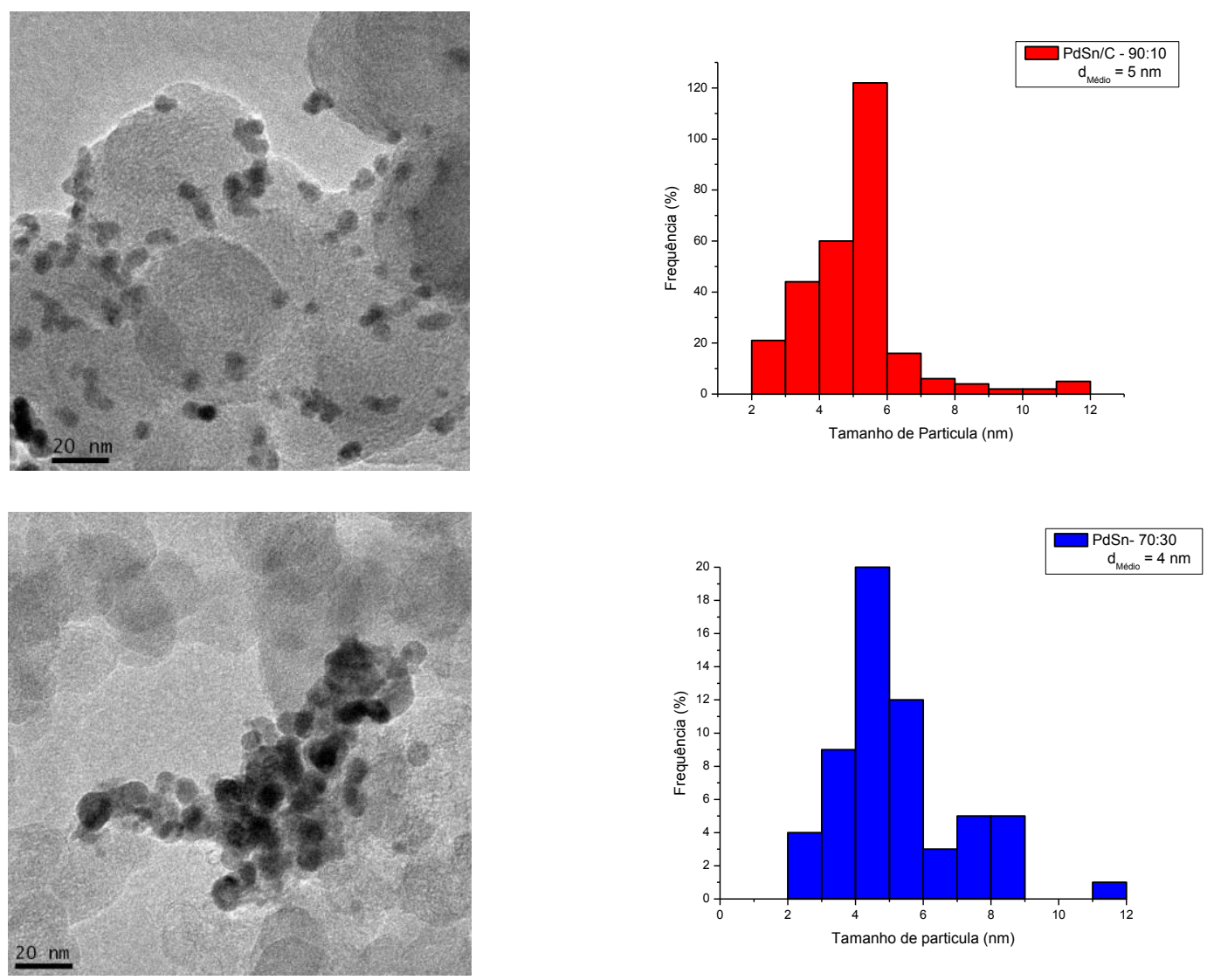

c)
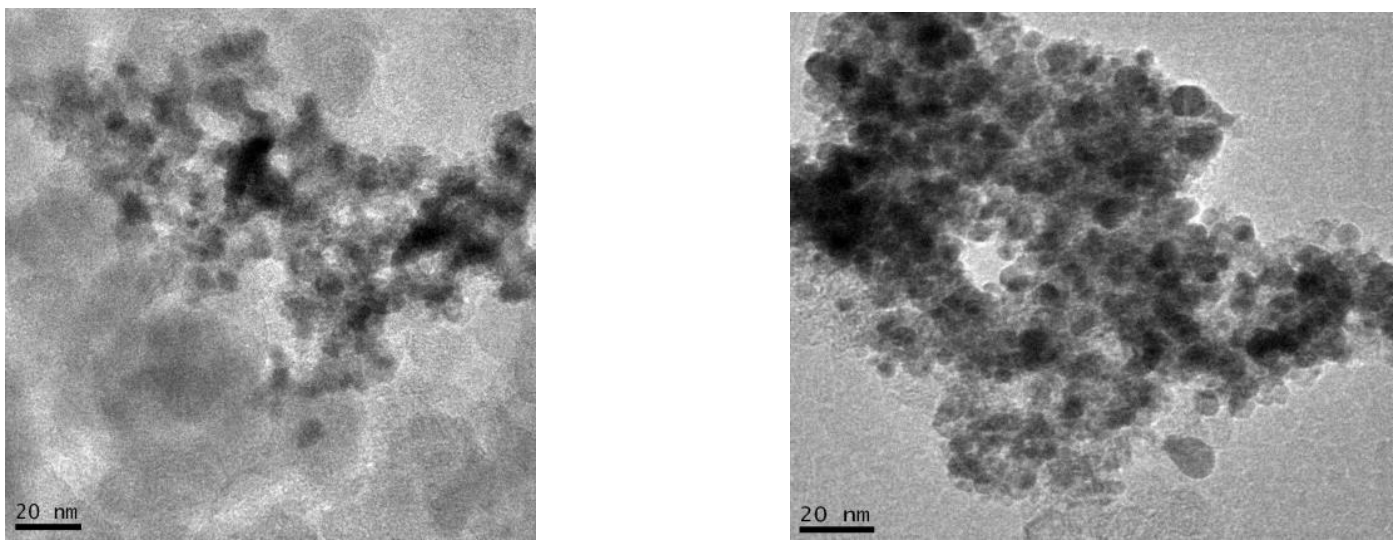

FIGURA 18 - Micrografias obtidas por microscopia eletrônica de transmissão e distribuição dos tamanhos de partícula dos catalisadores eletroquímicos preparados pelo método do borohidreto: (a) PdSn/C (90:10), (b) PdSn/C (70:30) e (c) PdSn/C (50:50). 
Os voltamogramas cíclicos dos catalisadores eletroquímicos de $\mathrm{Pd} / \mathrm{C}$, $\mathrm{PdSn} / \mathrm{C}$ (90:10), PdSn/C (70:30) e PdSn/C (50:50) preparados pelo método do borohidreto, na ausência de álcool, estão apresentados na FIG. 19. A escolha destas três proporções de PdSn para os catalisadores eletroquímicos binários foram feitas para estudar como cada composição se comporta em relação à oxidação do EG (FIG. 20) e qual deles apresentam o melhor resultado.

As curvas voltamétricas em meio alcalino foram obtidas na presença do eletrólito $\mathrm{KOH}, 1,0 \mathrm{~mol}$. $\mathrm{L}^{-1}$, e registrado no intervalo de $-1,0 \mathrm{~V}$ a 0,2 $\mathrm{V} v \mathrm{vs} . \mathrm{Ag} / \mathrm{AgCl}$ $(\mathrm{E}=-0,9 \vee v s . \mathrm{ERH})$.

Na FIG. 19 são apresentados voltamogramas cíclicos correspondentes aos catalisadores eletroquímicos $\mathrm{PdSn} / \mathrm{C}$ em meio alcalino. Neste caso não é possível ver os picos associados com a adsorção/dessorção de hidrogênio na região de 0,85 a $-0,45 \mathrm{~V}$ (vs. $\mathrm{Ag} / \mathrm{AgCl}$ ), observa-se também um pico relacionado com a oxidação de $\mathrm{Pd}$ e $\mathrm{Sn}$ deslocado para potenciais mais positivos com o aumento da quantidade de $S n$ nos catalisadores, $\approx-0,45 \vee$ para $P d / C,-0,45 V$ para $P d S n / C$ 90:10, $-0,30 \vee$ para PdSn/C (70:30) e -0,25 V para PdSn/C (50:50). Esta ordem segue a mudança de parâmetros de rede representado na Fig .16 indicando que este pico de oxidação pode estar associado à formação de ligas, esta observação é semelhante à relatada por Modibedi et al[80], quando estudou materiais de PdSn em meio alcalino.

Uma análise da varredura também mostrou que na região I de adsorção/dessorção de $\mathrm{H}_{2}$, não existem picos definidos indicando que não ocorreu processo de adsorção de $\mathrm{H}_{2}$ sobre os catalisadores. Observa-se que para os catalisadores $\mathrm{PdSn} / \mathrm{C}$ a oxidação do $E G$ não tem inicio e estão praticamente suprimidos, e que, apenas para o catalisador PdSn/C (70:30), ocorre um pico em $-0,35 \mathrm{~V}$ (região II). Neste caso, espécies oxigenadas resultantes da adsorção da água começam a adsorver na superfície do catalisador PdSn (70:30) (processo de oxidação). O decréscimo do pico ocorreu devido ao inicio da adsorção de espécies oxigenadas na superfície do catalisador.

$\mathrm{Na}$ região III a camada de óxido formada deveria ser reduzida, liberando os sítios ativos da superficie do catalisador, mas este mecanismo não ocorreu. 


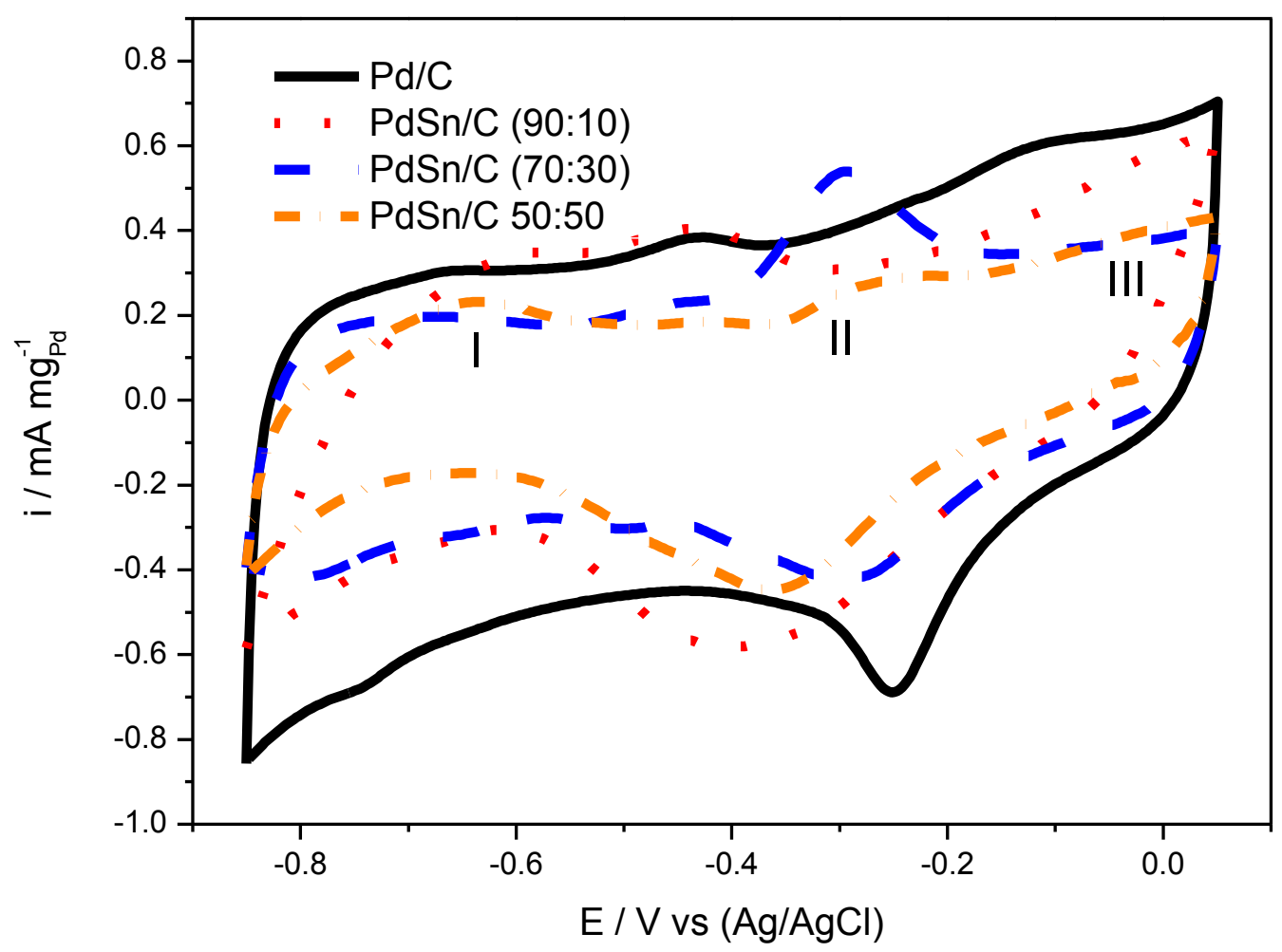

FIGURA 19 - Voltametria cíclica de Pd/C e PdSn/C em solução de $\mathrm{KOH} 1$ mol.L-1 com velocidade de varredura de $10 \mathrm{mV} \mathrm{s}^{-1}$.

Na FIG. 20a é mostrada a curva de voltametria de varredura linear anódica dos catalisadores eletroquímicos de $\mathrm{Pd} / \mathrm{C}$ e $\mathrm{PdSn} / \mathrm{C}$ em solução de $\mathrm{EG} 1 \mathrm{~mol} . \mathrm{L}^{-1} \mathrm{em}$ $\mathrm{KOH} 1 \mathrm{~mol} . \mathrm{L}^{-1}$ saturado com $\mathrm{N}_{2}$ com velocidade de varredura de $10 \mathrm{mV}^{\mathrm{s}} \mathrm{s}^{-1}$. Com este experimento é possível notar que todos os materiais contendo $\mathrm{Sn}$ apresentam um potencial menos positivo $(\approx-0,57 \mathrm{~V})$ do que $\mathrm{Pd}(\approx-0,50 \mathrm{~V})$. Indicando que a adição de $\mathrm{Sn}$ nos catalisadores eletroquímicos de $\mathrm{Pd}$ diminui o sobrepotencial da reação de oxidação, esta mudança é relatado na literatura para PtSn e PdSn para outros álcoois, tais como metanol e etanol [85-93]. Dentre todos os materiais estudados por voltametria cíclica os catalisadores eletroquímicos de PdSn/C (70:30 e 50:50) foram os mais ativos em toda a faixa de potencial estudada indicando serem candidatos promissores para os testes em célula a combustível alimentada diretamente por EG. 

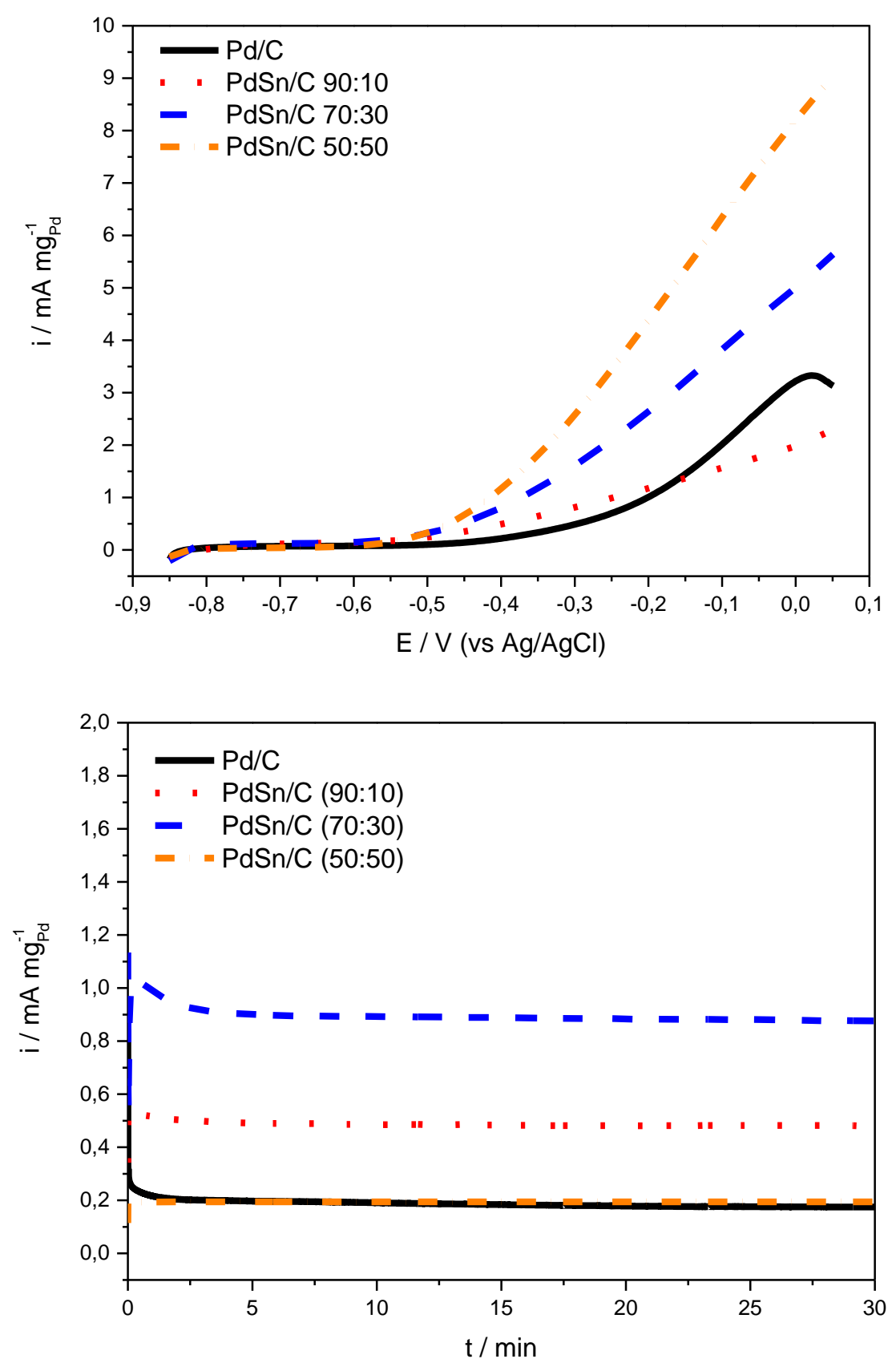

FIGURA 20: a) Voltametria de varredura linear anódica para os catalisadores eletroquímicos de $\mathrm{Pd} / \mathrm{C}$ e $\mathrm{PdSn} / \mathrm{C}$ em solução de $\mathrm{EG} 1 \mathrm{~mol} . \mathrm{L}^{-1} \mathrm{em}$ $\mathrm{KOH} 1 \mathrm{~mol}^{-\mathrm{L}^{-1}} \mathrm{com}$ velocidade de varredura de $10 \mathrm{mV} \mathrm{s}^{-1}$, b) Curvas cronoamperométricas em EG 1 mol.L-1 em KOH 1 mol.L-1 para os catalisadores eletroquímicos $\mathrm{Pd} / \mathrm{C}$ e $\mathrm{PdSn} / \mathrm{C}$ em diferentes composições, preparados pelo método de borohidreto, no potencial de $-0,35 \mathrm{~V}$ (vs. $\mathrm{Ag} / \mathrm{AgCl})$ a $25^{\circ} \mathrm{C}$. 
A estabilidade dos materiais $\mathrm{PdSn} / \mathrm{C}$ foi avaliada por cronoamperometria (FIG. 20b). As curvas de cronoamperometria dos catalisadores eletroquímicos de $\mathrm{PdSn} / \mathrm{C}$ e $\mathrm{Pd} / \mathrm{C}$ foram realizadas em EG 1 mol.L-1 em KOH 1 mol. $\mathrm{L}^{-1}$ a um potencial fixo de $-0,35 \vee$ (vs $\mathrm{Ag} / \mathrm{AgCl}$ ). Nos primeiros segundos, os catalisadores eletroquímicos mostraram grandes decréscimos e após 5 minutos todos os materiais atingiram uma corrente razoavelmente estável até chegar ao fim dos 30 minutos de experimeto. Neste período de tempo as medidas da densidade da corrente foram de $0,17 \mathrm{~mA} \cdot \mathrm{mg}_{\mathrm{Pd}}^{-1}$ para $\mathrm{Pd} / \mathrm{C}, 0,48 \mathrm{~mA} \cdot \mathrm{mg}_{\mathrm{Pd}}^{-1}$ para $\mathrm{PdSn} / \mathrm{C}(90: 10)$, 0,88 mA.mg ${ }_{\text {Pd }}^{-1}$ para PdSn/C (70:30), e 0,19 mA.mg ${ }_{\text {Pd }}^{-1}$ para PdSn/C (50:50). Os estudos com a técnica de cronoamperometria mostrou que o catalisador eletroquímico de $\mathrm{PdSn} / \mathrm{C}$ (70:30) foi o mais ativo para a oxidação do $\mathrm{EG}$, ou seja, este se mantém ativo mesmo quando maiores tempos de operação são exigidos em um determinado potencial.

A medida da atividade para a maioria dos materiais contendo Sn é maior do que unicamente $\mathrm{Pd} / \mathrm{C}$, mesmo que o catalisador $\mathrm{Sn} / \mathrm{C}$ não tenha se mostrado ativo para a oxidação de EG. $O$ aumento da atividade pode ser explicada como um resultado da reação cinética e da estrutura eletrônica do material, indicando o deslocamento dos parâmetros de rede da liga $\mathrm{PdS} n^{[21,25,80]}$, o que alteraria a maneira com que ocorre a adsorção de álcool e influenciaria nos produtos formados.

O catalisador eletroquímico PdSn/C (50:50) mostrou maior densidade de corrente do que os outros materiais em experimentos de voltametria, no entanto, durante a cronoamperometria este material perdeu a atividade nos primeiros segundos, depois estabilizou-se até atingir o tempo de 30 minutos de experimento, com uma densidade de corrente próximo do catalisador $\mathrm{Pd} / \mathrm{C}$.

O melhor desempenho eletroquímico de $\mathrm{PdSn} / \mathrm{C}$ (70:30) pode ser atribuido ao efeito sinérgico entre a facilitação da oxidação do álcool através de espécies contendo oxigênio adsorvido em átomos de $\mathrm{Sn}^{[7,25,56]}$, portanto o mecanismo bifuncional não poderia ser descartado.

Os espectros de FTIR (FIG. 21) foram realizados de modo a correlacionar a atividade de oxidação eletroquímica do $E G$ com as principais vias de formação ${ }^{[7,85]}$. Os espectros de FTIR na região entre 3000 a $850 \mathrm{~cm}^{-1}$ foram registrados durante 
oxidação eletroquímica do etileno glicol para os catalisadores eletroquímicos $\mathrm{Pd} / \mathrm{C} \mathrm{e}$ $\mathrm{PdSn} / \mathrm{C}$ em solução de EG 1 mol.L-1 em KOH 1 mol.L-1. Considerando os espectros resultantes foi possível observar o aparecimento de bandas relacionadas com a formação de $\mathrm{CO}_{2}$ a $2343 \mathrm{~cm}^{-1}$ e de íons de carbonato a $1370 \mathrm{~cm}^{-1}$. No entanto, para os catalisadores eletroquímicos $\mathrm{PdSn} / \mathrm{C}(90: 10)$ e (70:30), o espectro não é claramente visível devido a uma alta interferência atribuída à banda de carboxilato a $1390 \mathrm{~cm}^{-1}$. Pode ser visto em $1072 \mathrm{~cm}^{-1} \mathrm{o}$ estiramento de aldeídos (glioxal, glicolato, gliceraldeído) e em $1240 \mathrm{~cm}^{-1}$ o C-O de glicolato ou oxalato.

As alterações nas concentrações de espécies específicas produzidas durante a oxidação do EG (aumento ou diminuição) foram analisadas por funções lineares Lorentzianas. Assim, a intensidade e a largura da linha de cada banda puderam ser analisadas individualmente, conforme mostram os gráficos (FIG.22-25) de intensidade integrada das bandas de estiramento do aldeído (glioxal, glicolato, gliceraldeído), estiramento de oxalato, glicerato e oxalato[7,78,85].

Na FIG. 22 estão as intensidades integradas das bandas de estiramento do aldeído $\left(1072 \mathrm{~cm}^{-1}\right)$ e é possível notar que a adição de $\mathrm{Sn}$ não contribui para a formação de aldeído e o potencial é deslocado em $100 \mathrm{mV}$ mais positivos do que os potenciais de $\mathrm{Pd} / \mathrm{C}$. Sobre o comportamento desta banda vale ressaltar que $\mathrm{O}$ catalisador eletroquímico PdSn/C-70:30 apresenta um perfil divergente dos outros materiais, caracterizado pela intensidade de sinal mais baixo e o consumo da banda em -0.55 V, que pode indicar uma baixa produção de grupo aldeído e oxidação deste grupo em maior sobrepotencial.

Analisando a banda $1320 \mathrm{~cm}^{-1}$ (FIG. 23a) atribuída ao ácido carboxílico produzido durante a oxidação do EG, os principais ácidos carboxílicos que foram formados e mencionados na literatura são o ácido glicolato e ácido oxalato[85], apresentam uma faixa por volta de $1240 \mathrm{~cm}^{-1}$ (FIG. 23b) correspondente ao alongamento $\mathrm{O}-\mathrm{H}^{[85]}$ e é possível ver que esta espécie não aparece para os catalisadores estudados, com exceção ao PdSn/C (70:30), com uma intensidade crescente até $-150 \mathrm{mV}$ e depois começa a diminuir. O perfil divergente obtido para a banda $1320 \mathrm{~cm}^{-1}$ que corresponderia aos ácidos carboxílicos, indica que a combinação de $\mathrm{Pd}$ e Sn têm uma preferência para a formação de oxalato em vez de glicolato. 

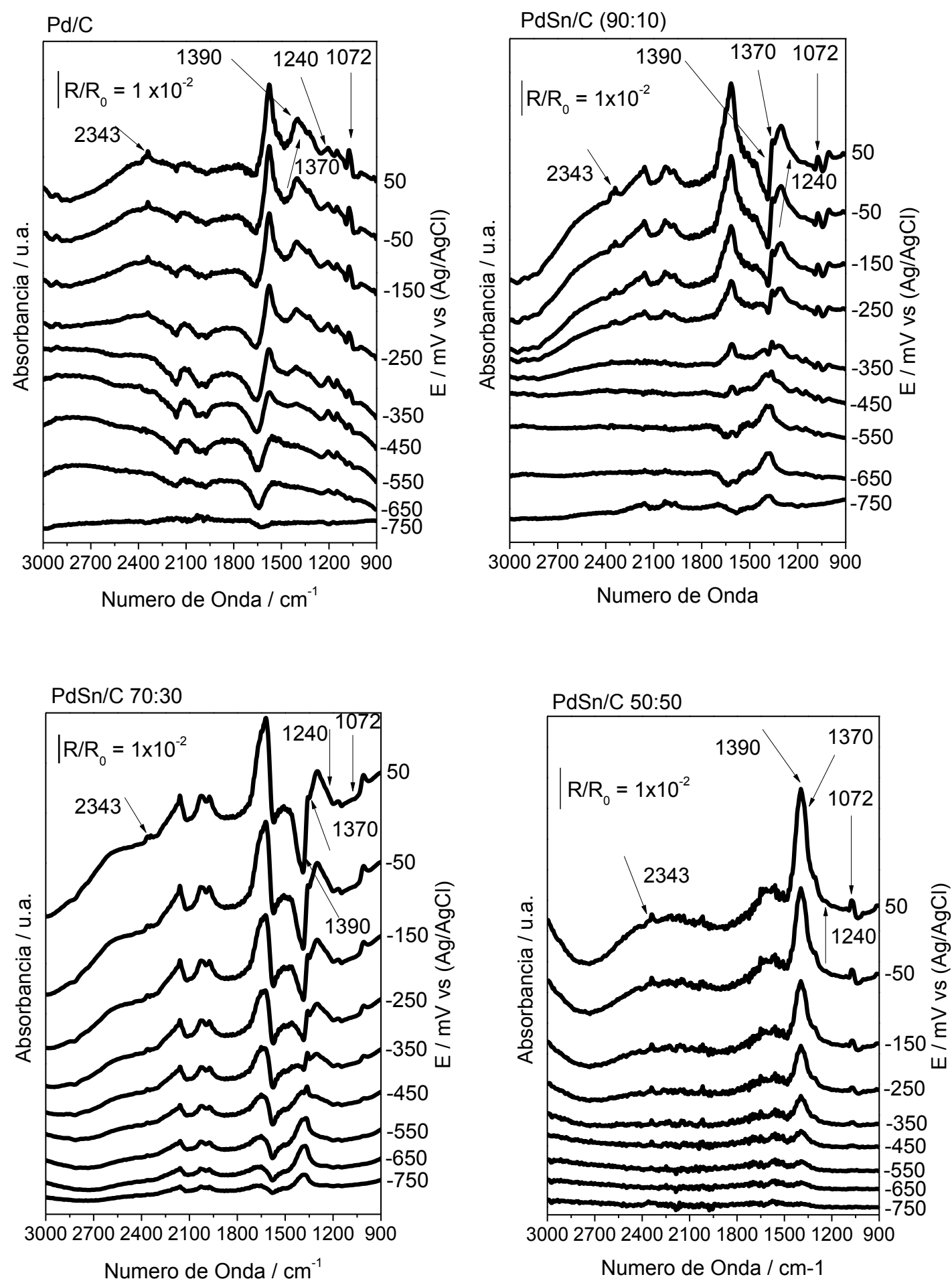

FIGURA 21 - Espectros de absorção ATR-FTIR in situ coletados no intervalo de potenciais de $-0,8$ a $0,1 \vee$ (vs $\mathrm{Ag} / \mathrm{AgCl})$, em solução aquosa de $\mathrm{EG}$ $1 \mathrm{~mol}^{-L^{-1}} \mathrm{em} \mathrm{KOH} 1 \mathrm{~mol}^{-L^{-1}}$ para os catalisadores eletroquímicos de $\mathrm{Pd} / \mathrm{C}$ e $\mathrm{PdSn} / \mathrm{C}$. Os backgrounds foram coletados em $-0.85 \mathrm{~V}$ (vs $\mathrm{Ag} / \mathrm{AgCl}$ ), a uma velocidade de varredura de $1 \mathrm{mV} \mathrm{s}^{-1}$. 


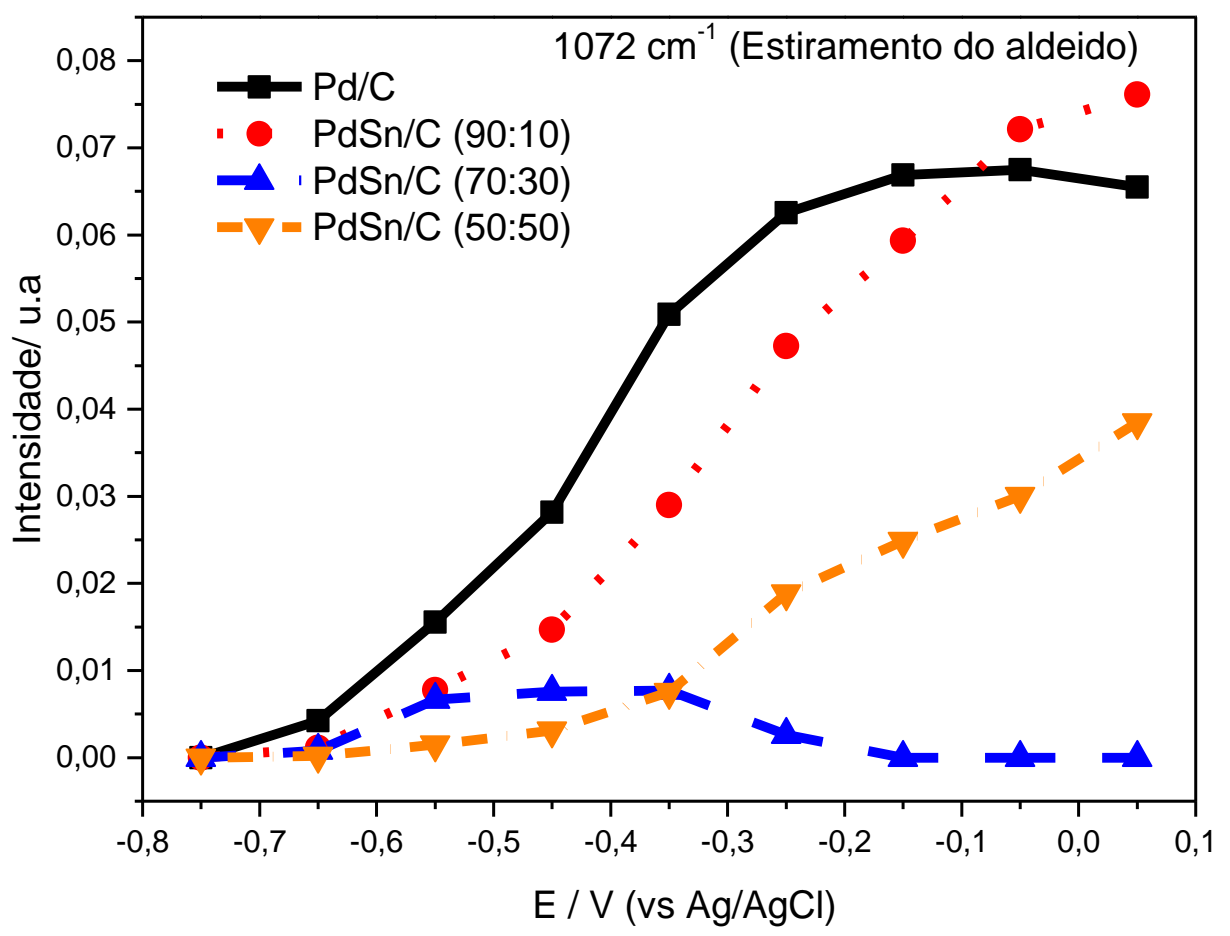

FIGURA 22 - Intensidade Integrada das bandas do aldeído $\left(1072 \mathrm{~cm}^{-1}\right)$ em função do potencial para os catalisadores eletroquímicos $\mathrm{Pd} / \mathrm{C}, \mathrm{PdSn} / \mathrm{C}$. Os backgrounds foram coletados em $-0.85 \mathrm{~V}$ (vs. Ag/AgCl), a uma velocidade de varredura de $1,0 \mathrm{mV} \mathrm{s}^{-1}$.

Na FIG. 24 a integração da banda $2343 \mathrm{~cm}^{-1}$, correspondente à formação de $\mathrm{CO}_{2}$, e pode ser observado que o aumento da quantidade de $\mathrm{Sn}$ no catalisador desloca o início de potencial da formação de $\mathrm{CO}_{2}$ para potenciais menos positivos, indicando que $\mathrm{Sn}$ ou $\mathrm{SnO}_{2}$ age na clivagem da ligação C-C. A banda $1367 \mathrm{~cm}^{-1}$, normalmente atribuída aos íons de carbonato, pode não ser descrito, devido à interferência de banda $1363 \mathrm{~cm}^{-1}$ de carbonato. 

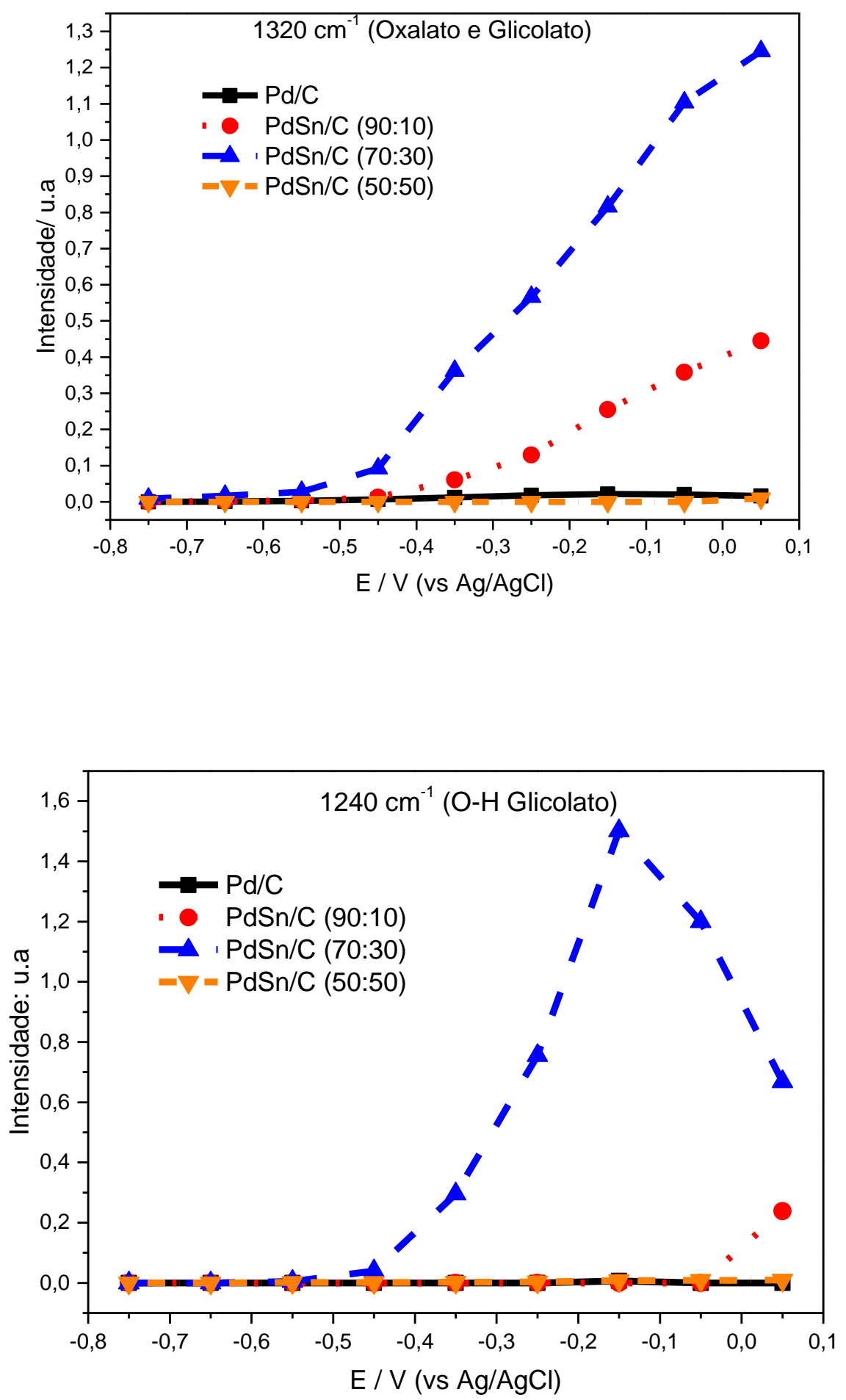

FIGURA 23 - Intensidade Integrada das bandas em função do potencial para os catalisadores eletroquímicos $\mathrm{Pd} / \mathrm{C}$ e $\mathrm{PdSn} / \mathrm{C}$ (a) oxalato e glicolato, (b) estiramento $\mathrm{O}-\mathrm{H}$ do oxalato. 


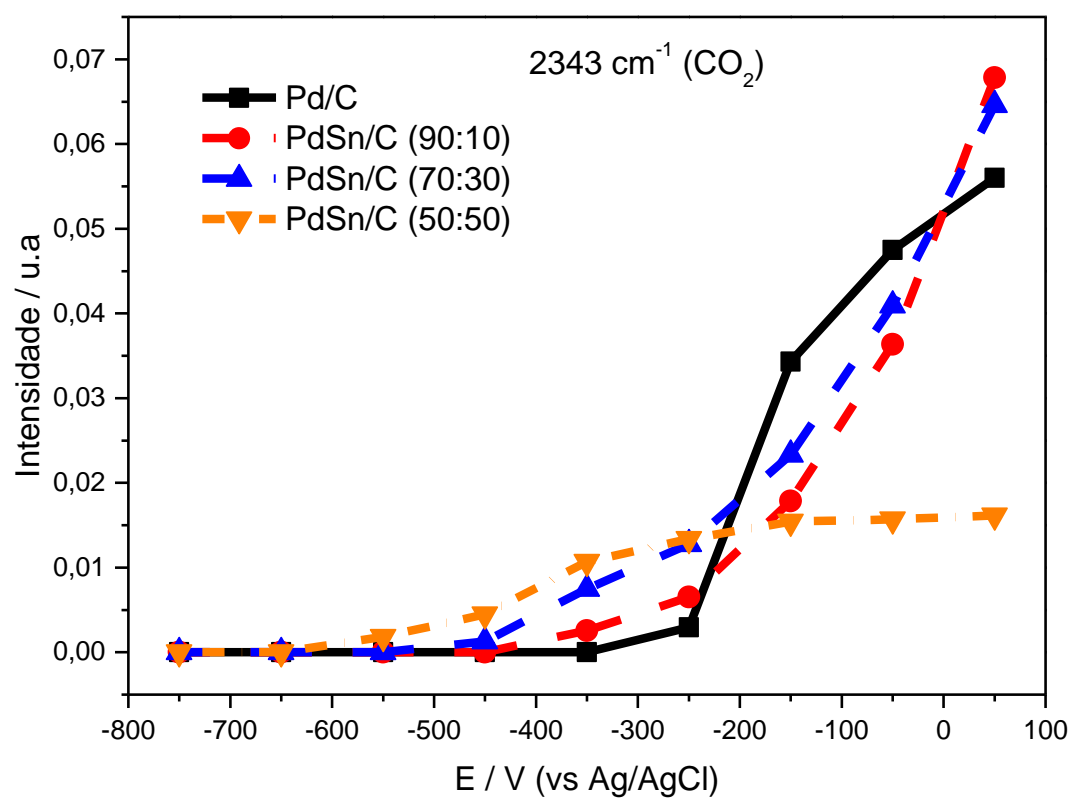

FIGURA 24 - Intensidade integrada das bandas de $\mathrm{CO}_{2}\left(2343 \mathrm{~cm}^{-1}\right)$ em função do potencial para os catalisadores eletroquímicos de $\mathrm{Pd} / \mathrm{C}$ e $\mathrm{PdSn} / \mathrm{C}$.

$\mathrm{Na}$ FIG. 25 são apresentados os desempenhos dos catalisadores eletroquímicos $\mathrm{Pd} / \mathrm{C}, \mathrm{PdSn} / \mathrm{C}$ em célula a combustível alcalina unitária alimentada diretamente por EG. Observa-se que o OCV (Open Circuit Voltage ou potencial de circuito aberto) para o material contendo $\mathrm{Sn}$ é maior do que o catalisador eletroquímico $\mathrm{Pd} / \mathrm{C}$, resultado que está de acordo com o observado nos experimentos de voltametria ciclíca (FIG.19). As curvas de densidade de potência indicam que os catalisadores eletroquímicos contendo $S n$ são mais ativos para a reação de oxidação do EG, especialmente a composição PdSn/C (70:30) $\left(15 \mathrm{~mW} . \mathrm{cm}^{-2}\right)$, apresentando uma medida de potência quase três vezes maior do que $\mathrm{Pd} / \mathrm{C}\left(\approx 6 \mathrm{~mW} \cdot \mathrm{cm}^{-2}\right)$, sendo esta uma ótima composição binária para oxidação do EG. Esta atividade pode ser atribuída à adsorção do álcool sobre o catalisador eletroquímico de modo que mostrou alteração no parâmetro de rede favorecendo uma rápida formação de produtos oxidados, tais como oxalato, como observado por experiências in situ de ATR-FTIR. 


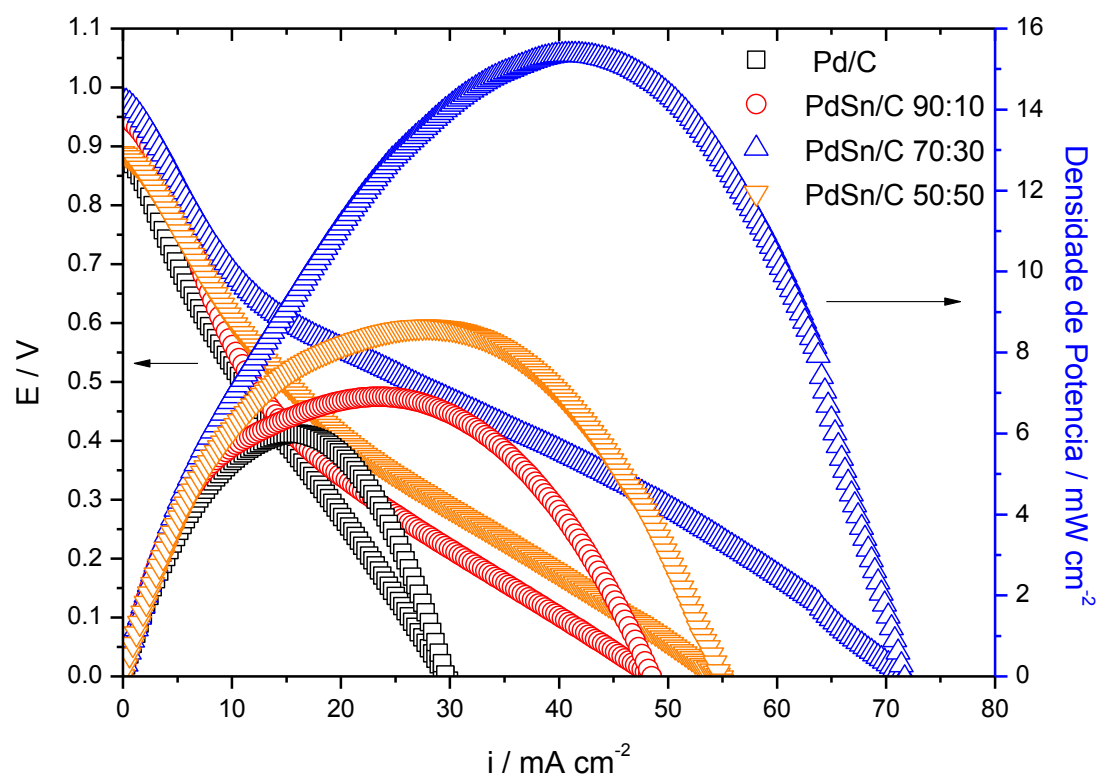

FIGURA 25 - Desempenho da célula a combustível em etileno glicol para os catalisadores eletroquímicos $\mathrm{Pd} / \mathrm{C}$ e $\mathrm{PdSn} / \mathrm{C}$ a $100{ }^{\circ} \mathrm{C}$, preparados pelo método do borohidreto, membrana de Nafion 117 tratada com $\mathrm{KOH}$, eletrólito de $\mathrm{EG}+\mathrm{KOH}\left(2 \mathrm{~mol} \cdot \mathrm{L}^{-1}\right)$, fluxo de $1 \mathrm{~mL} \cdot \mathrm{min}^{-1}$.

\subsubsection{Catalisador PtPd/C}

A FIG. 26 mostra os difratogramas de raio-X para os catalisadores eletroquímicos de $\mathrm{Pt} / \mathrm{C}, \mathrm{Pd} / \mathrm{C}$ e $\mathrm{PtPd} / \mathrm{C}$ preparados pelo método da redução por borohidreto. Os difratogramas indicam que todos os materiais apresentaram a mesma estrutura da platina e do paládio, cúbica de face centrada (CFC), sem uma mudança nas posições dos picos para valores baixos de $2 \theta$. Devido ao fato dos picos de difração da Pt e do Pd serem muito próximos, existe uma certa dificuldade em visualizar qualquer deslocamento nos picos dos catalisadores constituidos por ambos os metais (Pt ou $\mathrm{Pd}$ ) em relação aos picos dos catalisadores $\mathrm{Pt} / \mathrm{C}$ e $\mathrm{Pd} / \mathrm{C}$.

Os quatro picos de difração observados em, aproximadamente $2 \theta=40^{\circ}, 46^{\circ}$, $68^{\circ}$ e $82^{\circ}$ estão associados com os planos cristalinos (111), (200), (220) e (311), 
respectivamente. O parâmetro de rede de materiais à base de Pt é de 0,392 nm e dos materiais à base de $\mathrm{Pd}$ é de $0,389 \mathrm{~nm}^{[7,25]}$. Observa-se que a inserção de $\mathrm{Pd}$ na síntese dos catalisadores eletroquímicos não alterou o tamanho médio de cristalito (TAB. 5). Tal comportamento pode ser comprovado pela simples observação da posição dos picos nos difratogramas de raios-X.

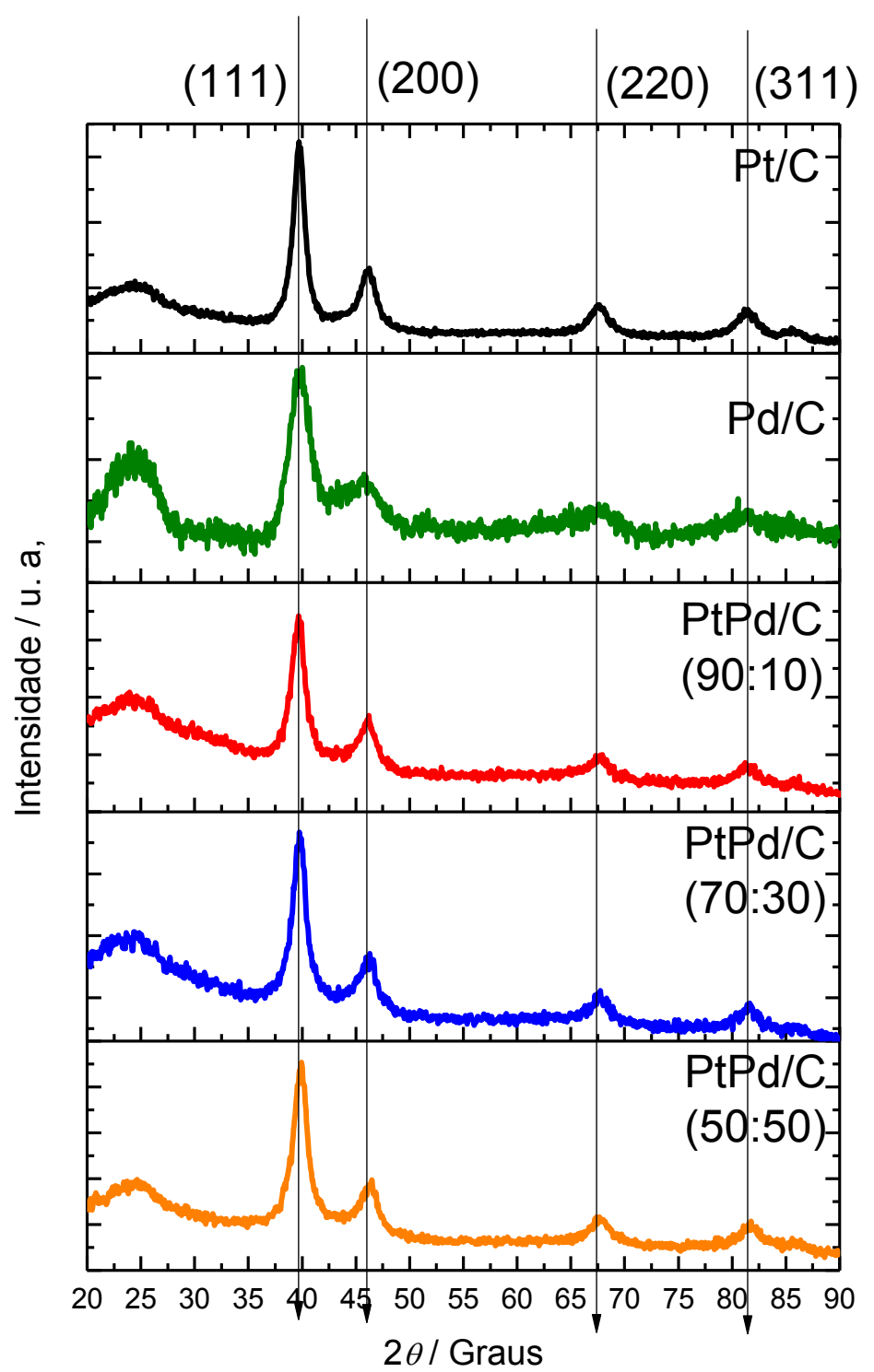

FIGURA 26 - Difratogramas dos catalisadores eletroquímicos $\mathrm{Pt} / \mathrm{C}, \mathrm{Pd} / \mathrm{C}$ e do $\mathrm{PtPd} / \mathrm{C}$ suportados em carbono

Os catalisadores eletroquímicos foram caracterizados por EDX para obtenção de suas razões molares e para a certificação da composição dos mesmos. Na TAB. 5 são mostrados os resultados do tamanho médio de cristalito, os parâmetros de 
rede obtidos pelos difratogramas de DRX e a composição dos catalisadores em \% mol obtidos por EDX. Para todos os catalisadores eletroquímicos sintetizados à base $\mathrm{Pt}$ e Pd sobre substrato de carbono, os valores das razões molares obtidas por EDX foram próximos aos valores nominais, confirmando que o método por borohidreto é eficiente para produção dos catalisadores propostos.

TABELA 5 - Tamanho médio de cristalito, parâmetro de rede e composição em $\%$ mol por EDX para catalisadores eletroquímicos à base $\mathrm{Pt}$ e $\mathrm{Pd}$ sobre substrato de carbono.

\begin{tabular}{lccc}
\hline $\begin{array}{c}\text { Catalisadores } \\
\text { Eletroquímicos }\end{array}$ & $\begin{array}{c}\text { Tamanho médio } \\
\text { de cristalito } \\
(\mathbf{n m})\end{array}$ & $\begin{array}{c}\text { Parâmetro de } \\
\text { rede } \\
(\mathbf{n m})\end{array}$ & $\begin{array}{c}\text { Composição EDX } \\
(\% \text { mol) }\end{array}$ \\
\hline $\mathrm{Pt} / \mathrm{C}$ & 5 & 0.392 & $100: 0$ \\
$\mathrm{Pd} / \mathrm{C}$ & 5 & 0.389 & $100: 0$ \\
$\mathrm{PtPd} / \mathrm{C}(90: 10)$ & 5 & 0,392 & $92: 8$ \\
$\mathrm{PtPd} / \mathrm{C}(70: 30)$ & 5 & 0,392 & $74: 26$ \\
$\mathrm{PtPd} / \mathrm{C}(50: 50)$ & 5 & 0,393 & $57: 43$ \\
\hline
\end{tabular}

As imagens por MET foram realizadas com o intuito de avaliar a distribuição e o tamanho médio das partículas dos catalisadores de Pt/C (100:0), Pd/C (100:0). No catalisador $\mathrm{Pt} / \mathrm{C}$ e $\mathrm{Pd} / \mathrm{C}$, as nanopartículas de platina e paládio dispersas no suporte de carbono exibiram um tamanho médio de partícula de 5 nm (FIG.7a) e (FIG.17a), respectivamente.

Na FIG.27 são apresentadas as imagens por MET dos catalisadores eletroquímicos PtPd/C (90:10); (70:30); (50:50), e seus respectivos histogramas da distribuição de frequência dos tamanhos das partículas. Nestes catalisadores o tamanho médio de partícula foi de $5 \mathrm{~nm}$. 
a)

b)
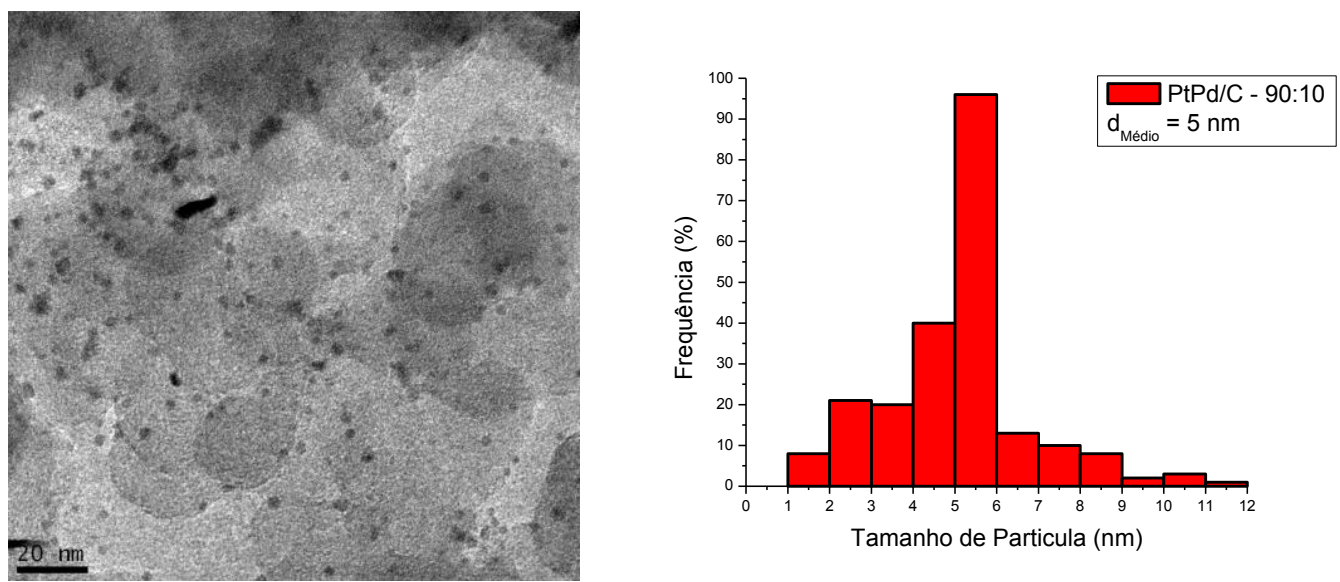

c)
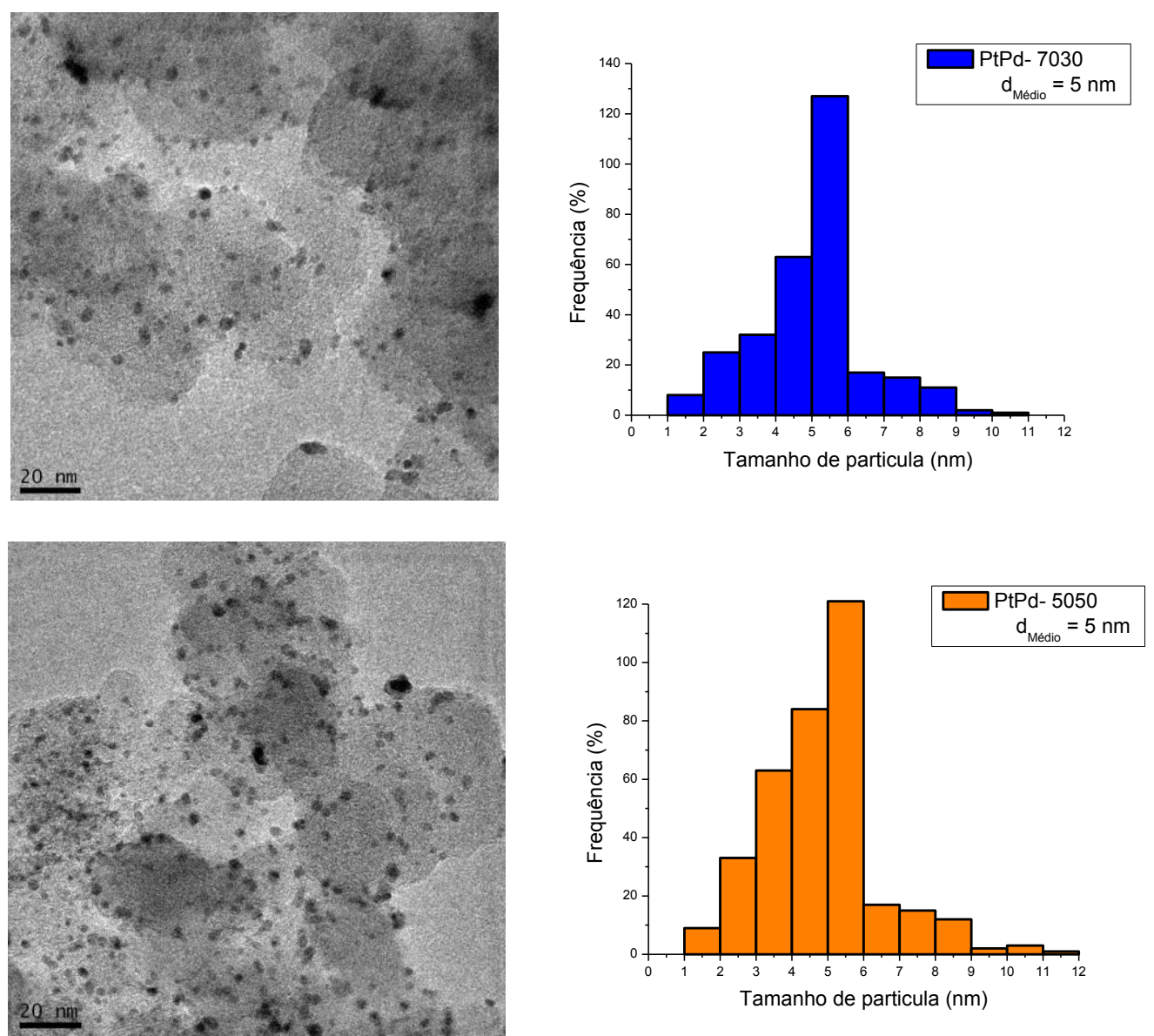

FIGURA 27 - Micrografias obtidas por microscopia eletrônica de transmissão e distribuição dos tamanhos de partícula dos catalisadores eletroquímicos preparados pelo método do borohidreto: (a) PtPd/C (90:10), (b) PtPd/C (70:30) e (c) PtPd/C (50:50). 
Os resultados obtidos por MET mostram que as nanopartículas de Pt e de Pd estão distribuídas de forma homogênea nos suportes de carbono. As áreas mais claras que aparecem principalmente na periferia das imagens são denominadas regiões semitransparentes representam os agregados das partículas de carbon black. As esferas escuras são as partículas de platina e de paládio, cujos diâmetros médios variaram de 2 a $5 \mathrm{~nm}$.

As imagens por MET permitem comparar os diferentes catalisadores eletroquímicos, PtSn - 70:30 (FIG. 8 (b)); PdSn - 70:30 (FIG. 18 (b)) e PtPd - 70:30 (FIG. 27 (b)). Observa-se que os cocatalisadores de Sn apresentaram aglomerados das partículas, enquanto que o cocatalisador $\mathrm{Pd}$ não apresentou aglomerados, indicando que houve uma boa dispersão.

Os voltamogramas cíclicos dos catalisadores eletroquímicos de $\mathrm{Pt} / \mathrm{C}, \mathrm{Pd} / \mathrm{C}$ e PtPd/C (90:10); (70:30); (50:50), preparados pelo método do borohidreto, na ausência de álcool, estão apresentados na FIG.28. A escolha destas três proporções de PtPd para os catalisadores eletroquímicos binários teve por objetivo estudar como cada composição se comporta em relação a oxidação do EG (FIG.29).

As curvas voltametricas em meio alcalino foram obtidas na presença do eletrólito $\mathrm{KOH}, 1,0 \mathrm{~mol} . \mathrm{L}^{-1}$, registrado no intervalo de $-1,0 \mathrm{~V}$ a $0,2 \mathrm{~V}(\mathrm{vs} . \mathrm{Ag} / \mathrm{AgCl})$.

Na FIG.28 são apresentados os voltamogramas cíclicos correspondentes aos catalisadores eletroquímicos Pt/C, Pd/C e PtPd/C (90:10); (70:30); (50:50), em meio alcalino. Neste caso é possível ver os picos associados com a adsorção/dessorção de hidrogênio na região de $-0,70$ a $-0,30 \mathrm{~V}(\mathrm{vs}$. Ag/AgCl). Observa-se, também, um pico relacionado com a oxidação de $\mathrm{Pt}$ e $\mathrm{Pd}$ deslocado para potenciais mais positivos com o aumento da quantidade de $\mathrm{Pd}$ nos catalisadores, $\approx-0,40 \mathrm{~V}$ para $\mathrm{PtPd} / \mathrm{C}$ (90:10), -0,36 V para PtPd/C (70:30) e -0,34 V para PtPd/C (50:50).

Nos voltamogramas cíclicos correspondentes aos catalisadores eletroquímicos em meio alcalino há três regiões anódicas. Observa-se que na região I houve um deslocamento da posição dos picos para os catalisadores eletroquímicos de PtPd indicando a transformação no arranjo de átomos de platina quando comparado ao catalisador $\mathrm{Pt} / \mathrm{C}$. 
Na região II não existem prepicos. Os prepicos na superfície do catalisador é resultado de uma forte interação entre $\mathrm{EG}$ e $\mathrm{O}_{2}$ adsorvido, o que resulta em espécies fortemente adsorvidas, como exemplo $\mathrm{CO}$ adsorvido linearmente. Como não ocoreu a formação de pré-picos nesta região isso pode indicar que o $\mathrm{CO}$ não esta adsorvido linearmente.

Os perfis voltamétricos na região II (dupla camada eletrica- DCE) mostram um aumento nos valores de corrente para catalisadores eletroquímicos de PtPd em relação ao $\mathrm{Pd} / \mathrm{C}$ e $\mathrm{Pt} / \mathrm{C}$, atribuindo maior formação de espécies oxigenadas.

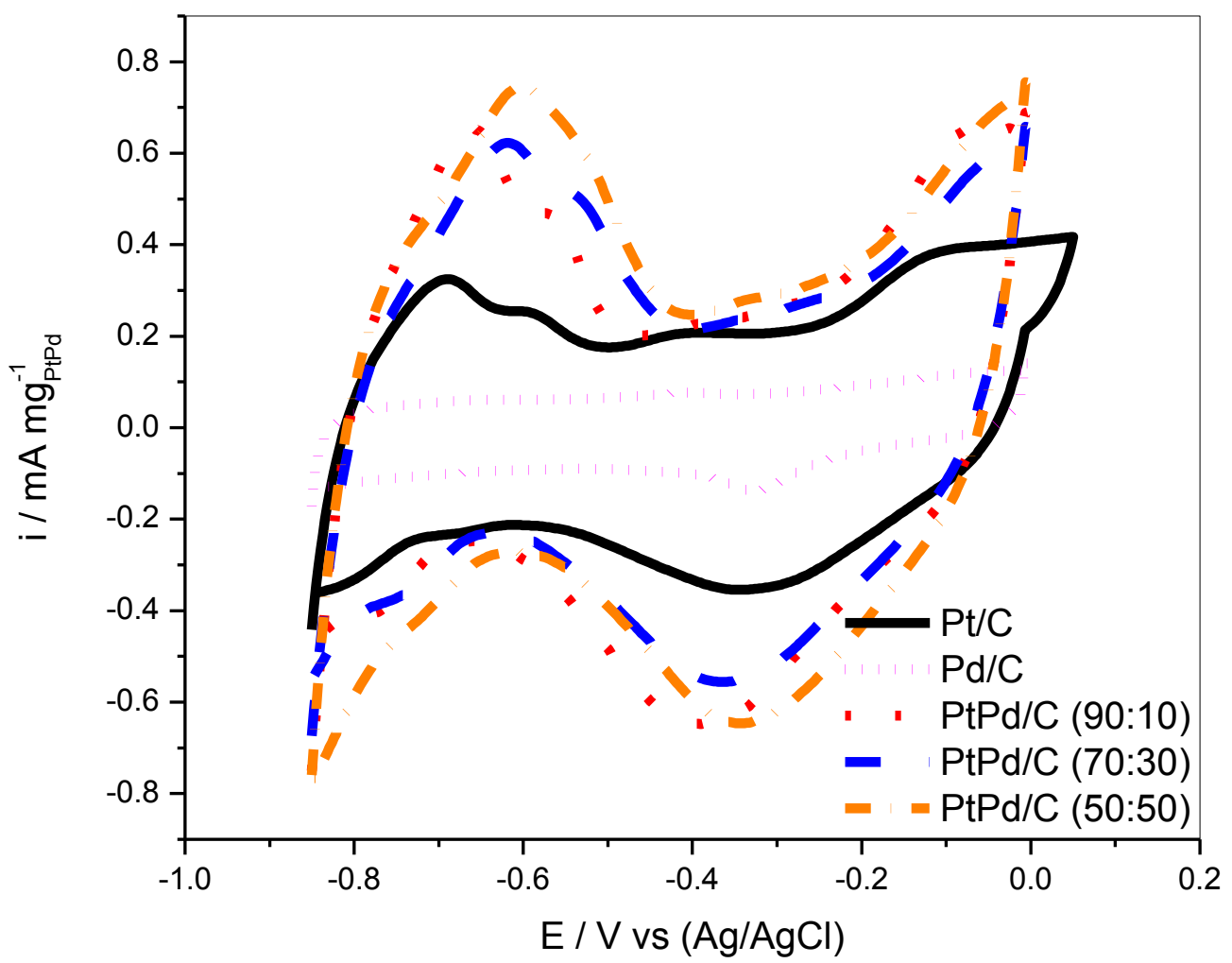

FIGURA 28 - Voltametria cíclica de Pt/C, Pd/C e PtPd/C (90:10); (70:30); (50:50), em solução de $\mathrm{KOH}$ 1,0 mol.L-1 com velocidade de varredura de $10 \mathrm{mV} \cdot \mathrm{s}^{-1}$. 
$\mathrm{Na}$ FIG.29a é mostrada a curva de voltametria de varredura linear dos catalisadores eletroquímicos de $\mathrm{Pt} / \mathrm{C}, \mathrm{Pd} / \mathrm{C}$ e $\mathrm{PtPd} / \mathrm{C}$ em solução de $\mathrm{EG} 1,0 \mathrm{~mol} . \mathrm{L}^{-1}$ em KOH 1,0 mol.L-1 saturado com $\mathrm{N}_{2}$ com velocidade de varredura de $10 \mathrm{mV}^{-\mathrm{s}^{-1}}$.

Com este experimento é possível ver que os potenciais da reação de oxidação do EG estão muito próximos de $-0,69 \vee(v s$. $\mathrm{Ag} / \mathrm{AgCl}$ ). Dentre todos os materiais estudados por voltametria cíclica o catalisador eletroquímico de PtPd/C (70:30) foi o mais ativo em toda a faixa de potencial estudada indicando ser um candidato promissor para os testes em célula a combustível alimentadas diretamente por EG.

A estabilidade dos materiais PtPd/C foi avaliada usando experimentos de cronoamperometria, FIG.29b. As curvas de cronoamperometria dos catalisadores eletroquímicos de Pt/C, Pd/C e PtPd/C (90:10); (70:30); (50:50), foram obtidas em EG 1 mol.L-1 em KOH 1 mol.L-1 a um potencial fixo de $-0,35 \vee(v s$. $\mathrm{Ag} / \mathrm{AgCl})$. Nos primeiros segundos, os catalisadores eletroquímicos de PtPd/C mostraram acréscimo na corrente e, após 5 minutos, todos os materiais atingiram uma corrente razoavelmente estável até chegar ao fim dos 30 minutos de experimento. Neste período de tempo as medidas da densidade da corrente foram de 1,46 mA.mg $\mathrm{Pt}^{-1}$ para Pt/C, 0,17 mA.mg ${ }_{\text {Pd }}^{-1}$ para Pd/C, $1,48 \mathrm{~mA} \cdot \mathrm{mg}_{\mathrm{PtPd}}^{-1}$ para PtPd/C (90:10), 1,91 mA.mg PtPd estudos com a técnica de cronoamperometria confirmaram que o catalisador eletroquímico de PtPd/C (70:30) foi mais ativo para a oxidação do EG, ou seja, o mesmo se mantém ativo quando maiores tempos de operação são exigidos em um determinado potencial.

A medida da atividade para a maioria dos materiais contendo $\mathrm{Pd}$ é maior do que unicamente $\mathrm{Pt} / \mathrm{C}$, Este aumento da atividade pode ser explicado como um resultado da cinética da reação e da estrutura eletrônica do material, o que alteraria a maneira em que ocorre a adsorção de álcool e influenciaria nos produtos formados.

O catalisador eletroquímico PtPd/C 50:50 apresentou uma densidade de corrente próxima do PtPd/C (70:30) em experimentos de voltametria e 
cronoamperometria. Este material mostrou aumento de atividades nos primeiros segundos, mas depois estabilizou-se até atingir o tempo de 30 minutos de experimento, com uma densidade de corrente próxima do catalisador PtPd/C 70:30.

O melhor desempenho eletroquímico de PtPd/C (70:30) poderia ser devido ao efeito sinérgico entre a facilitação da oxidação do álcool através de espécies contendo oxigênio adsorvido em átomos de $\mathrm{Pd}$, contudo o mecanismo bifuncional não poderia ser descartado. O catalisador eletroquímico PtPd/C (90:10) apresenta menor atividade em relação aos outros catalisadores e, provavelmente, o cocatalisador não fonece espécies oxigenadas suficientes para a oxidação do EG.

$\mathrm{Na}$ FIG.30 estão os desempenhos dos catalisadores eletroquímicos $\mathrm{Pt} / \mathrm{C}$, $\mathrm{Pd} / \mathrm{C}$ e $\mathrm{PtPd} / \mathrm{C}$ em célula a combustível alcalina unitária alimentada diretamente por EG. As curvas de densidade de potência indicam que os catalisadores eletroquímicos contendo $\mathrm{Pd}$ são mais ativos para a reação de oxidação do $E G$, especialmente as composições PtPd/C $(70: 30)\left(\approx 30 \mathrm{~mW} \cdot \mathrm{cm}^{-2}\right)$ e PtPd/C $(50: 50)(\approx$ $\left.28 \mathrm{~mW} \cdot \mathrm{cm}^{-2}\right)$, tendo uma medida de potência maior do que $\mathrm{Pt} / \mathrm{C}\left(\approx 10 \mathrm{~mW} \cdot \mathrm{cm}^{-2}\right)$. Esta atividade pode ser atribuída à adsorção do álcool sobre os catalisadores eletroquímicos, que favorece uma rápida formação de produtos oxidados. 

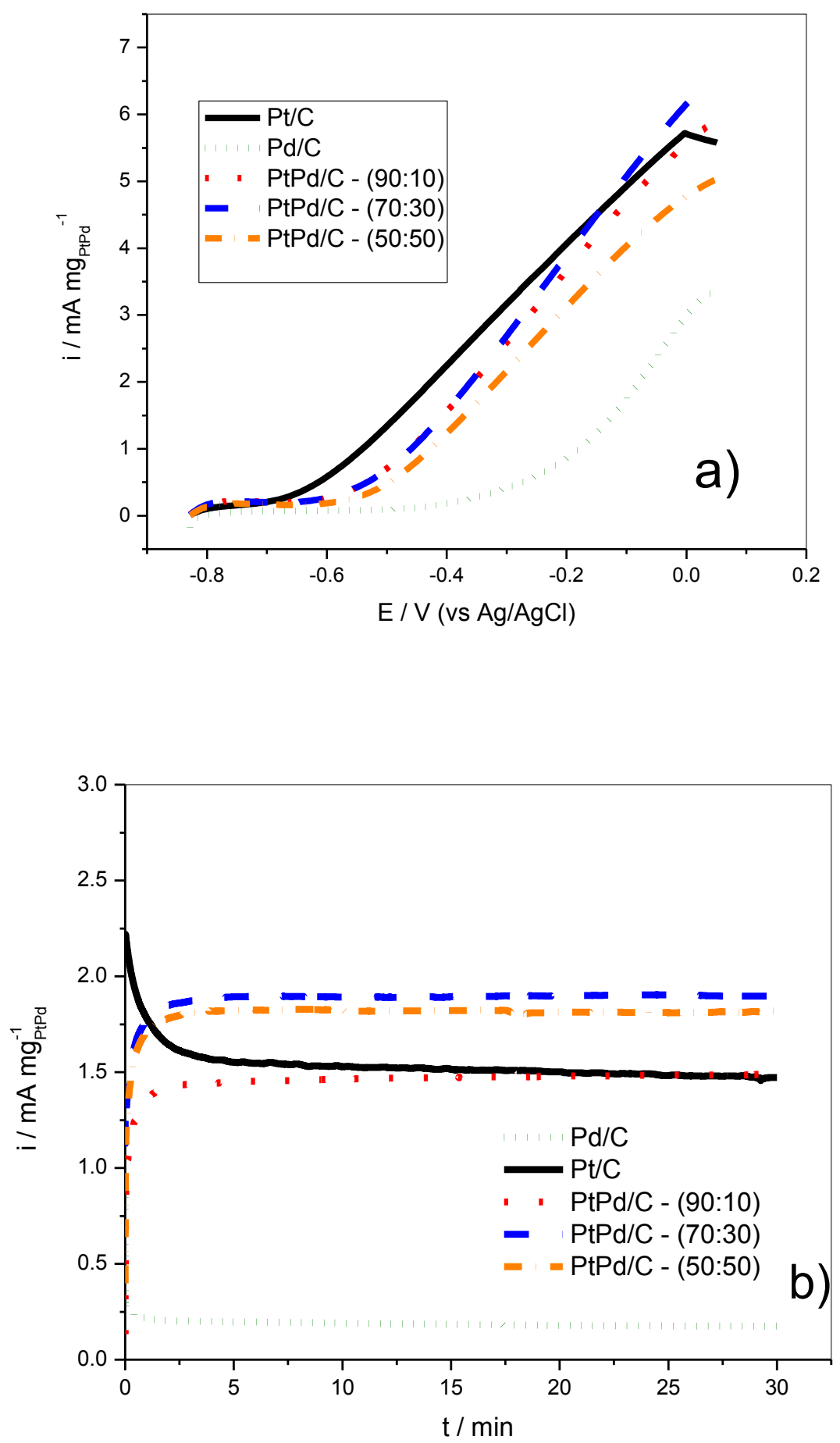

FIGURA 29: (a) Voltamogramas cíclicos para os catalisadores eletroquímicos de

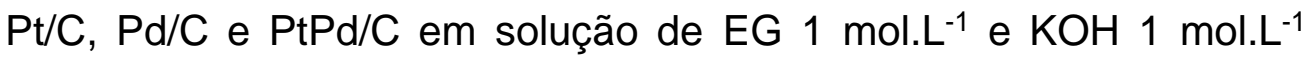
com velocidade de varredura de $10 \mathrm{mV} \cdot \mathrm{s}^{-1}$; (b) Curvas de cronoamperometrias em EG 1 mol.L-1 e KOH 1,0 mol.L-1 para os catalisadores eletroquímicos $\mathrm{PtPd} / \mathrm{C}$ em diferentes composições preparados pelo método de borohidreto no potencial de $-0,35 \mathrm{~V}$ (vs. $\mathrm{Ag} / \mathrm{AgCl})$ à $25^{\circ} \mathrm{C}$. 


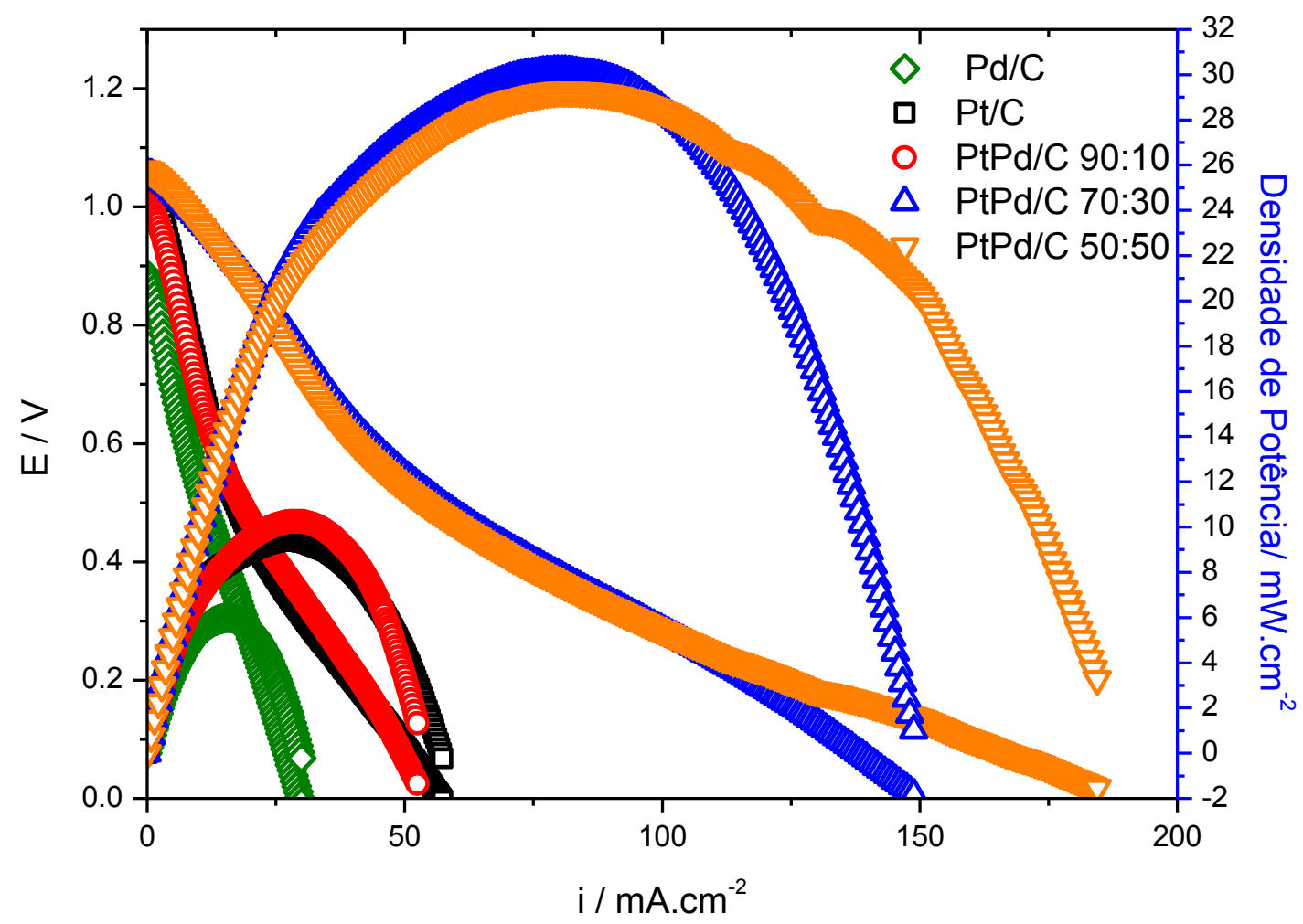

FIGURA 30 - Desempenho da célula a combustível em etileno glicol para os catalisadores eletroquímicos Pt/C, Pd/C e PtPd/C a $100{ }^{\circ} \mathrm{C}$, preparados pelo método do borohidreto, membrana de Nafion 117 tratada com $\mathrm{KOH}$, eletrólito de $\mathrm{EG}+\mathrm{KOH}\left(2 \mathrm{~mol}^{\mathrm{L}} \mathrm{L}^{-1}\right)$, fluxo de 1 $\mathrm{mL} \cdot \mathrm{min}^{-1}$.

$\mathrm{A}$ adição do cocatalisador $\mathrm{Pd}$ nos catalisadores eletroquímicos $\mathrm{PtPd} / \mathrm{C}$ provoca uma modificação na densidade eletrônica dos sitios de adsorção superficiais destes catalisadores. Este mecanismo pode provocar um aumento da adsorção das moléculas do EG pelos sitios da $\mathrm{Pt}$, associados aos sitios do $\mathrm{Pd}$, que fornece espécies $\mathrm{OH}^{-}$. Com a adsorção das hidroxilas $\left(\mathrm{OH}^{-}\right)$pelos sitios de $\mathrm{Pd}$, os sitios de Pt estão livres do recobrimento de espécies intermediárias e livres para adsorver o EG. 
Observa-se, também, que os catalisadores PtSn/C e PdSn/C apresentaram baixa densidade de potência (TAB.6) nos testes de célula a combustível unitária utilizando EG, quando comparado ao catalisador PtPd/C provavelmente a adição do cocatalisador de Pd fornece espécies oxigenadas à Pt e favorece a oxidação do EG, evitando a desativação do catalisador PtPd, o que resulta maior densidade de potência.

TABELA 6 - Composição dos catalisadores binários e suas densidades de potência determinadas na operação de uma célula a combustível alcalina unitária.

\begin{tabular}{cc}
\hline Catalisadores & $\begin{array}{c}\text { Densidade de } \\
\text { Potência } \\
\left(\mathrm{mW} . \mathrm{cm}^{-2}\right)\end{array}$ \\
\hline$P t / C$ & 10 \\
$P d / C$ & 6 \\
$P t S n / C$ (90:10) & 10,5 \\
$P t S n / C$ (70:30) & 14,5 \\
$P t S n / C$ (50:50) & 12 \\
$P d S n / C$ (90:10) & 7 \\
$P d S n / C$ (70:30) & 15 \\
$P d S n / C$ (50:50) & 9 \\
$P t P d / C(90: 10)$ & 10,5 \\
$P t P d / C$ (70:30) & 30 \\
$P t P d / C$ (50:50) & 28 \\
\hline
\end{tabular}




\section{CONCLUSÕES}

De acordo com os dados apresentados, foi possível atestar a eficiência do método da redução via borohidreto na produção de catalisadores eletroquímicos binários para a oxidação do etileno glicol em meio alcalino.

Os resultados de EDX para os catalisadores eletroquímicos mostraram que os valores das razões molares são similares aos valores nominais.

Os difratogramas de raios $\mathrm{X}$ dos catalisadores eletroquímicos mostraram uma estrutura cúbica de face centrada típica da platina e do paládio. Em relação ao catalisador eletroquímico de Sn pode ocorrer a formação de óxidos de estanho que devido a sua estrutura amorfa não é detectado nos difratogramas.

Os catalisadores eletroquímicos de $\mathrm{PtSn} / \mathrm{C}$ analisados não apresentaram formação de ligas, no entanto, os de $\mathrm{PdSn} / \mathrm{C}$ apresentaram uma expansão do parâmetro de rede indicando formação de ligas. Para o $\mathrm{PtPd} / \mathrm{C}$, devido ao fato dos picos de difração da Pt e do Pd serem muito próximos, existe uma certa dificuldade em visualizar qualquer deslocamento nos picos dos catalisadores constituídos por ambos os metais (Pt ou $\mathrm{Pd}$ ) em relação aos picos dos catalisadores $\mathrm{Pt} / \mathrm{C}$ e $\mathrm{Pd} / \mathrm{C}$.

A técnica de espectroscopia de ATR-FTIR in situ sobre os catalisadores eletroquímicos Pt/C, Pd/C, PtSn/C e PdSn/C - nas proporções (90:10), (70:30) e (50:50) - mostraram que a oxidação do EG ocorre pelo mecanismo indireto, ou seja via formação de oxalato e glicolato.

De acordo, com os resultados de densidade de potência os catalisadores binários PtPd/C foram mais ativos em relação aos catalisadores binários PtSn/C e $\mathrm{PdSn} / \mathrm{C}$ devido à adição do cocatalisador de $\mathrm{Pd}$, que fornece espécies oxigenadas para a Pt e favorece a oxidação do EG, evitando a desativação do catalisador PtPd, o que resulta em uma maior densidade de potência. A adição do cocatalisador $\mathrm{Pd}$ nos catalisadores eletroquímicos PtPd/C provoca uma modificação na densidade eletrônica dos sitios de adsorção superficiais destes catalisadores. Este mecanismo pode provocar um aumento da adsorção das moléculas do EG pelos sitios da $\mathrm{Pt}$, 
associados aos sitios do $\mathrm{Pd}$, que fornece espécies $\mathrm{OH}^{-}$. Com a adsorção das hidroxilas $\left(\mathrm{OH}^{-}\right)$pelos sitios de $\mathrm{Pd}$, os sitios de Pt estão livres do recobrimento de espécies intermediárias e livres para adsorver o EG.

Os catalisadores eletroquímicos de PtSn são menos ativos, pois não há uma sinergia entre os metais. Desta forma necessita-se maior energia para romper as ligações das moléculas de água $(\mathrm{H}-\mathrm{OH})$ e fornecer espécies oxigenadas, necessárias para o processo de oxidação do EG. Por consequência, existe uma fraca interação, entre a superficie do catalisador e as moléculas de EG.

Os resultados experimentais mostraram que o melhor desempenho de uma célula unitária alcalina pode ser atribuído ao aumento das cinéticas, tanto da reação de oxidação do EG, quanto da reação de redução do oxigênio, e, também, aos parâmetros operacionais, como concentração do $E G$ e do $\mathrm{KOH}$ e da temperatura de funcionamento das $\mathrm{CaC}$; fatores que apresentam influência positiva significativa. 


\section{REFERÊNCIAS BIBLIOGRÁFICAS}

[1] Lopes, P. P.; Ticianelli, E. A.; Estudo do efeito de tratamento térmicos em catalisadores de $\mathrm{PtRu} / \mathrm{C}$ frente à reação de oxidação de hidrogênio na presença de CO. Quím. Nova, v. 30, n. 5, p. 1256-1260, 2007.

[2] Linardi, M.; Introdução à ciência e tecnologia de células a combustível, $1^{\text {a }}$ ed.; ArtLiber: São Paulo, 2010.

[3] Wendt, H.; Linardi, M.; Arico, E. M. Células a combustível de baixa potência para aplicações estacionárias. Quím. Nova, v. 25, n. 3, p. 470-476, 2002.

[4] Gonzalez, E. R.; Eletrocátalise e poluição ambiental. Quím. Nova, vol. 23, n. 2, p. 262-266, 2000.

[5] Steele, B. C. H.; Heinzel, A. Materials for fuel cell tecnologies. Nature, v..414, p. 345-352, 2001.

[6] Shlapback, L.; Zuttel, A. Hydrogen-storage materials for móbile applications. Nature, v..414, p. 353-358, 2001.

[7] Piasentin, R. M.; Estudo da eletro-oxidação do etanol utilizando eletrocatalisadores $P t P d / C+A T O$ e $P t P d S n / C+A T O$ preparados via redução por borohidreto de sódio. 2013. Tese (Doutorado), Instituto de Pesquisas Energéticas e Nucleares, São Paulo.

[8] Wilson, M.S.; Gotterfeld, S. High performance catalyzed membranes of ultra-low Pt loadings for polymer electrolyte fuel cells. J. Appl. Electrochem., v. 139, p. 28-30, 1992.

[9] Esmaeilifar, A.; Rowshanzamir, S.; Eikani, M. H.; Ghazanfari, E. Preparation of low-platinum-loading electrocatalysts using electroless deposition method for proton exchange membrane, Electrochim. Acta, v.56, p. 271-277, 2010.

[10] Hennings,U.; Reimert, R. Noble metals catalysts supported on gadolinium doped ceria used for natural gas reforming in fuel cell applications. Appl. Catal., B, v. 70, p. 498-508, 2007.

[11] Wilson, M. S.; Gotterfeld, S. Thin-film catalyst layers for polymer electrolyte fuel cell electrodes. J. Appl. Electrochem., v. 22, p. 1-7, 1992.

[12] Wilson, M. S.; Gotterfeld, S. High performance catalyzed membranes of ultralow Pt loadings for polymer electrolyte fuel cells. J. Appl. Electrochem., v. 139, p. 28-30, 1992. 
[13] Bianchini, C.; Shen, P. K. Palladium-based electrocatalysts for alcohol oxidation in half cells and in direct alcohol fuel cells. Chem. Rev., v.109, p. 41834206, 2009.

[14] Xu, C.; Shen, P.k.; Liu, Y. Ethanol electrooxidation on $\mathrm{Pt} / \mathrm{C}$ and $\mathrm{Pd} / \mathrm{C}$ catalysts promoted with oxide. J. Power Sources, v.164 p. 527-531, 2007.

[15] Savadogo, O.; Lee, K.; Oishi, K.; Mitsushima, S.; Kamiya, N.; Ota, K. I. New palladium alloys catalyst for the oxygen reduction reaction in an acid medium. Electrochem Commun. v. 6, p.105-109, 2004.

[16] Pattabiraman, R. Electrochemical investigations on carbon supported palladium catalysts. Appl. Catal., A: General, v. 153, p. 9-20, 1997.

[17] Haan, J. L.; Sttaford, K. M.; Morgan, R. D.; Masel, R. I. Performance of direct formic acid fuel cell with electrochemically modified palladium-antimony anode catalyst. Electrochim. Acta, v. 55, p. 2477-2481, 2010.

[18] Park, K.; Han, D.; Sung, Y. PtRh ally nanoparticle eletrocatalysts for oxygen reduction for use in direct methanol fuel cells. J. Power Sources, v. 163, p. 8286, 2006.

[19] Pereira, L. G. S.; Pereira, M. E.; Ticianelli, E. A.; Influência de $M / C(M=M o$, $\mathrm{Cu}, \mathrm{Fe}$ e W) incorporado à camada difusora do eletrodo de difuso de gás frente à reação de oxidação de hidrogênio na presença de CO. Quím. Nova, v. 30, n. 7, p.1644-1648, 2007.

[20] Ticianelli, E. A.; Camara, G. A.; Santos, L. G. R. A. Eletrocatalise das reações de oxidação de hidrogênio e de redução de oxigênio. Quím. Nova, v. 28, n. 4, p. 664-669, 2005.

[21] Chu, D.; Wang, J,; Wang, S.; Zha, L.; he, J.; Hou, Y.; Yan, Y.; Lin, H.; Tian, Z. High activity of $\mathrm{Pd}-\mathrm{In}_{2} \mathrm{O}_{3} / \mathrm{CNTS}$ eletrocatalyst for electro-oxidation of ethanol. Catal. Commun., v. 10, p. 955-958, 2009.

[22] Zhao, T. S.; Li, Y.S.; Shen, S. Y. Anion-exchange membrane direct ethanol fuel cells: Status and perspective, Energy Power Eng. China, v. 4, p. 443-458, 2010.

[23] Blomen, L. J. M. J.; Mugerwa, M. N. Fuel cells systems. New York, NY; Plenum, 1993.

[24] Antolini, E.; Gonzalez, E. R.. Alkaline direct alcohol fuel cells. J. Power Sources, v.195, n. 11, p. 3431-3450, 2010.

[25] Brandalise, M.; Preparação e caracterização de eletrocatalisadores a base de paládio para oxidação eletroquímica de alcoóis e, meio alcalino. 2012. Tese (Doutorado), Instituto de Pesquisas Energéticas e Nucleares, São Paulo. 
[26] Perles, C. E.; Desenvolvimento de membranas de Nafion para aplicações em células a combustível do tipo PEMFC. Polímeros: Ciência e Tecnologia, v. 18, n. 4, p. 281-288, 2008.

[27] Wendt, H.; Götz, M.; Tecnologia de Células a Combustível. Química Nova, v..23, n. 4, p. 539-546, 2000.

[28] Grigoriev, S. A.; Lyutikova, E.K.; Martemianov, S.; Fateev, V.N..On the possibility of replacement of $\mathrm{Pt}$ by $\mathrm{Pd}$ in a hydrogen electrode of PEM fuel cells. Int. J. Hidrogen Energy, v. 32, p. 4438-4442, 2007.

[29] Fernandes, C. A.; Estudo do desempenho e degradação de catalisadores e membranas em células a combustível de eletólito polimérico. 2009. Tese (Doutorado), Instituto de Química de São Carlos, São Paulo.

[30] Kardigan, F.; Beden, B.; Léger, J. M.; Lamy, C.. Synergistic effect in the electrocatalytic oxidation of methanol on platinum + palladium alloy electrodes. $\boldsymbol{J}$. Electroanal. Chem., v. 125, n. 1, p. 89-103, 1981.

[31] Ferreira, H. A. R.; Catalisadores binários e ternários à base de Pt, Sn e Mo para aplicações em células a combustível. 2010. Tese (Doutorado), Universidade Federal da Paraíba, João Pessoa.

[32] Shao, M. Palladium-based electrocatalysts for hydrogen oxidation and oxygen reduction reactions. J. Power Sources, v. 196, p. 2433-2444, 2011.

[33] Antolini, E.; Zignani, S.C.; Santos, S.F.; Gonzalez, E.R. Palladium-based electrodes: A way to reduce platinum content in polymer electrolyte membrane fuel cells. Electrochim. Acta, v. 56, p. 2299-2305, 2011.

[34] Othman, R.; Dicks, A. L.; Zhu, Z.. Non precious metal catalysts for the PEM fuel cell cathode. Int. J. Hydrogen Energy, v. 37, p. 357-372, 2012.

[35] Oliveira Neto, A.; Perez, J.; Napporn, W. T.; Ticianelli, E. A.; Gonzaléz, E. R. Electrooxidation of methanol on binary platinum based catalysts. In: THIRD INTERNATIONAL SYMPOSIUM ON ELECTROCATALYSIS. WORKSHOP: ELECTROCATALYSIS IN INDIRECT AND DIRECT METHANOL PEM FUEL CELLS.., September 12-14, 1999, Portoroz. Proceedings... Portoroz. 1999. p. 83-86.

[36] Oliveira Neto, A.; Brandalise, M.; Dias, R. R.; Ayoub, J.M. S.; Silva, A. C.; Penteado, J. C.; Linardi, M.; Spinacé, E. V. The performance of Pt nanoparticles supported on $\mathrm{Sb}_{2} \mathrm{O}_{5} . \mathrm{SnO}_{2}$, on carbon and on physical mixtures of $\mathrm{Sb}_{2} \mathrm{O}_{5} . \mathrm{SnO}_{2}$ and carbon for ethanol electro-oxidation. Int. J. Hydrogen Energy, v. 35, n. 17, p. $9177-9181.2010$. 
[37] Piasentin R. M.; de Souza R. F. B.; Silva, J. C. M.; Spinacé, E. V.; Santos, M. C.; Oliveira Neto, A. Electro-oxidation of Ethanol on PtPdSn/C-Sb2 $\mathrm{O}_{5} . \mathrm{SnO}_{2}$ electrocatalysts prepared by borohydride reduction. Int J. Electrochem. Sci., v. 8, p. 435-445, 2013.

[38] Nandenha, J.; Souza, R. F. B.; Assumpção, M. H. M.T.; Spinacé, E. V.; Oliveira Neto, A. Preparation of $\mathrm{PdAu} / \mathrm{C}-\mathrm{Sb}_{2} \mathrm{O}_{5} \cdot \mathrm{SnO}_{2}$ electrocatalysts by borohydride reduction process for direct formic acid fuel cell. Ionics. p. 1-7, 2013.

[39] Sarto, F.; castagna, M.; de Francesco, T. M.; Dikonimos, L.. Giorgi, S.; T. M.; Lecci, S.; Sansovine, M.; Violante, V.. Morphology and electrochemical properties of Pd-based catalysts deposited by different thin-film techniques. International $\boldsymbol{J}$. Hydrogen Energy, v. 39, n. 27, p. 14701-14711, 2014.

[40] Roth, C.; Benker, N.; Theissmann, R.; Nichols, R.J.; Schiffrin, D.J. Bifunctional Electrocatalysis in Pt-Ru Nanoparticle Systems. Langmuir, v. 24, n. 5, p. 21912199, 2008.

[41] Iwasita , T. Electrocatalysis of methanol oxidation. Electrochim. Acta, v. 47, n. 22-23, p. 3663-3674, 2002.

[42] Batista, E. A.; Malpass, G. R. P.; Motheo, A.J.; Iwasita, T.; New mechanistic aspects of methanol oxidation, J. Electroanal. Chem., v. 571, p. 273-282, 2004

[43] Planes, G. A.; Garcia G.; Pastor, E., High performance mesoporous Pt electrode for methanol electrooxidation. A DEMS study, Electrochem. Commun., v. 9, p. 839-844, 2007.

[44] Prabhuram. J.; Manoharan, R.; Investigation of methanol oxidation on umsupported platinum electrodes in strong alkali and strong acid. J. Power Sources, v. 74, n. 1, p. 54-61, 1998.

[45] Tripkovic, A. V.; Popovic, K. D.; Grgur, B. N.; Blizanac, B.; Ross, P. N.; Markovic, N. M. Methanol electrooxidation on supported Pt and PtRu catalysts in acid and alkaline solutions. Electrochim. Acta, v. 47, n. 22-23, p. 3707-3714, 2002.

[46] Barroso, J.; Pierna, A. R.; Blanco, T. C.; Morallon, E.; Huerta, F. Homolytic cleavage C-C Bond in the electrooxidation of ethanol and bioethanol. $J$. Power Sources, v. 196, p. 4193-4199, 2011.

[47] Pramanik, H.; Basu, S. Modeling and experimental validation of overpotentials of a direct ethanol fuel cell. Chem. Eng. Proc., v.49, p. 635-642, 2010.

[48] An, L.; Zhao, T.S. Performance of an alkaline-acid direct ethanol fuel cell. Int. J. Hydrogen Energy, v.36, p. 9994-9999, 2011.

[49] Miyazaki, K.; Matsumiya, T.; Abe, T.; Kurata, H.; Fukutsuka, T.; Kojima, K.; Ogumi, Z. Electrochemical oxidation of ethylene glycol on Pt-based catalysts in alkaline solutions and quantitative analysis of intermediate products. Electrochim Act, v. 56, n. 22, p. 7610-7614, 2011. 
[50] Lima, R. B. Estudo da eletrooxidação do etileno glicol e de seus produtos de oxidação parcial em eletrodos de Pt e PtRu. 2006. Tese (Doutorado), Universidade de São Paulo, São Carlos.

[51] Christensen, P.A.; Hammet, A. The oxidation of ethylene glycol at platinum electrode in acid and base. An in situ FTIR study. J. Electroanal. Chem., v. 260, p. 347-359, 1989.

[52] Ureta-ZaÑartu, M.S.; YáÑez, C.; Páez, M.; Reyes, G. Electrocatalytic oxidation of ethylene glycol in $0.5 \mathrm{M} \mathrm{H}_{2} \mathrm{SO}_{4}$ and $0.5 \mathrm{M} \mathrm{NaOH}$ solutions at bimetallic deposited electrode. J. Electroanal. Chem., v. 405, p. 159-167, 1996.

[53] Kelaidopoulou, A.; Abelidou, E.; Papoutsis, A.; Polychroniadis, E.K.; Kokkinidis, G. Electrooxidation of ethylene glycol on Pt-based catalysts dispersed in polyaniline. J. Appl. Electrochem., v. 28, p. 1102-1106, 1998.

[54] Weaver,M. J.; Chang, S.-C.H.; Ho, Y.; Applications of real time FTIR spectroscopy to the elucidation of complex electroorganic pathways: eletrooxidation ethylene glycol on gold, platinum, nickel in alkaline solution. Journal of the American Chemical Society, v.113, p. 9506-9513, 1991.

[55] Silva, A.L.P. Eletrooxidation de etileno glicol sobre eletrodos Pt/C, $P t R u / C$ e Pt(RuO $) / C$. 2007. Dissertação (Mestrado), Universidade Federal do Maranhão, São Luiz.

[56] Oliveira Neto, A.; Vasconcelos, T.R.R.; Silva, R.W.R.V.; Linardi, M.; Spinacé, E.V. Electro-oxidation of ethylene glycol on PtRu/C and PtSn/C electrocatalysts prepared by alcohol-reduction process. J. Appl. Electrochem., v. 35, p. 193-198, 2005.

[57] Demarconnay, L.; Brimaud, S.; Contanceau, C.; Leger, J.M. Ethylene glycol electrooxidation in alkaline medium at multi-metallic Pt based catalysts. J. Electroanal. Chem., v. 601(1), p. 169,180, 2007.

[58] Livshits, V.; Philosoph, M.; Peled, E.. Direct ethylene glycol fuel-cell stackStudy of oxidation intermediate products. J. Power Sources, v. 178, p. 687-691, 2008.

[59] An, L.; Zhao, T.S.; Shen, S.Y.; Wu, Q. X.; Chen, R.Performance of a direct ethylene glycol fuel cell with an anion-exchange membrane. Int J. Hydrogen Energy, v.35, p. 4329-4335, 2010.

[60] Sieben, J.M.; Duarte, M. M. E. Methanol, ethanol, ethylene glycol electrooxidation at $\mathrm{Pt}$ and $\mathrm{Pt}-\mathrm{Ru}$ catalysts electrodeposited over oxidized carbon nanotubes. Int J. Hydrogen Energy, v.37, p. 9941-9947, 2012. 
[61] Couture, g.; Alaaeddine, A.; Boschet, F.; Ameduri, B. Polymeric materials as anion - exchange membranes for alkaline fuel cells. Prog. Polym. Sci., v. 36, n.11, p. 1521-1557, 2011.

[62] Oliveira neto, A.; Estudos eletroquímicos sobre eletrocatalisadores a base de platina dispersos em carbono de alta área superficial, 2001, Instituto de Química de São Carlos da Universidade de São Paulo, São Carlos.

[63] Santassalo - Aarnio, A.; Hietala, S.; Rauhala, T.; Kallio, T.. In and ex situ characterization of an anionex-change membrane for alkaline direct methanol fuel cell (ADMFC). J. Power Sources, v. 196, n.15, p. 6153 - 6159, 2011.

[64] Yu, E. h.; Scott, K. Development of direct methanol alkaline fuel cells using anion exchange membranes. J. Power Sources, v. 137, n. 2, p. 248-256, 2004.

[65] Varcoe, J. R.; Slade, R. C. T.; Yee, E. L. H.; Poynton, S. D.; Driscoll, D. J.. Investigation into the ex situ methanol, ethanol and ethylene glycol permeabilities of alkaline polymer electrolyte membranes. J. Power Sources, v. 173, n.1, p. 194-199, 2007.

[66] Abuin, G. C.; Nonjola, P.; Franceschini, E. A.; Izraelevitch, F. h.; Mathe, M. K.; Corte, H. R. Characterization of an anionic-exchange membranes for direcy methanol alkaline fuel cells. Int. J. Hydrogen Energy, v. 35, n. 11, p. 5849-5854, 2010.

[67] Kruissink, C. H. A. The effect of electro-osmotic water transporto $\mathrm{n}$ current efficiency and cell performance in chlor-alkali membrane electrolysis. J. Membr. Sci., v.14, n. 1-2, p. 331-366, 1983.

[68] Wee, J. H. A Comparison of sodium borohydride as a fuel for proton exchange membrane fuel cells and for direct borohydride fuel cells. J. Power Sources, v. 155, n. 1, p. 329-339, 2006.

[69] Jiang, L.; Sun, G.; Zhou, Z.; Zhou, W.; Xin, Q.; Preparation and characterization of $\mathrm{PtSn} / \mathrm{C}$ anode electrocatalysts for direct ethanol fuel cell. Catal. Today, v.93-95 p. 665-670, 2004.

[70] Brandalise, M.; Preparação e caracterização de eletrocatalisadores PtRu/C, PtBi/C, PtRuBi/C para eletro-oxidação direta de etanol em células a combustível tipo PEM utilizando a metodologia da redução via borohidreto de sódio. 2010. Dissertação (Mestrado), Instituto de Pesquisas Energéticas e Nucleares, São Paulo.

[71] Antoniassi, R. M. Desempenho elétrico distribuição dos produtos da célula a combustível com etanol direto utilizando Pt/C, PtSn/C (liga) e $\mathrm{PtSnO}_{2} / \mathrm{C}$ como eletrocatalisadores anódicos. 2013. Dissertação (Mestrado), Instituto de Pesquisa Energética e Nucleares, São Paulo. 
[72] Sieben, J. M.; Duarte, M. M. E. Nanostructured Pt and Pt-Sn catalysts supported on oxidized carbon nanotubes for ethanol and ethylene glycol electrooxidation. Int J. Hydrogen Energy, v.36 (5), p. 3313-3321, 2011.

[73] Godoi, D. R. M.; Perez, J.; Villullas, H. M.; Alloys and oxides on carbonsupported Pt-Sn electrocatalysts for ethanol oxidation. J. Power Sources, v.195, n.11, p. 3394-3401, 2010.

[74] Silva, J. C. M.; Da Silva, S. G.; De Souza, R. F. B.; Buzzo, G. S.; Spinacé, E.V.; Neto, A. O.; Assumpção, M. H. M. T. PtAu/C electrocatalysts as anodes for direct ammonia fuel cell. Appl. Catal., v. 490, p. 33-138, 2014.

[75] Oliveira Neto, A.; Nandenha, J.; Assumpção, M. H. M. T.; Linardi, M.; Spinacé, E. V.; de Souza, R. F. B. In situ spectroscopy studies of ethanol oxidation reaction using a single fuel cell/ATR-FTIR setup. Int J. Hydrogen Energy, v. 38, n. 25, p. 10585-10591, 2013.

[76] Falase, A.; Main, M.; Garcia, K.; Serov, A.; Lau, C.; Atanassov, P. Electrooxidation of ethylene glycol and glycerol by platinum-based binary and ternary nano-structured catalysts. Electrochim Acta, v. 66, n. 0, p. 295-301, 2012.

[77] Xin, L.; Zhang, Z.; Qi, J.; Chadderdon, D.; Li, W. Electrocatalytic oxidation of ethylene glycol (EG) on supported Pt and Au catalysts in alkaline media: Reaction pathway investigation in three-electrode cell and fuel cell reactors. Appl. Catal., v. 125, n. 0, p. $85-94,2012$.

[78] de Lima, R. B.; Paganin, V.; Iwasita, T.; Vielstich, W. On the electrocatalysis of ethylene glycol oxidation. Electrochim. Acta, v. 49, n. 1, p. 85-91, 2003.

[79] Silva, J. C. M.; Perreira, L.S.; De Souza, R.F.B.; Calegaro, M.L.; Spinacé, E.V.; Neto, A.O.; Santos, M.C. PtSn/C alloyed and non-alloyed materials: Differences in the ethanol electro-oxidation reaction pathways. Appl. Catal., v.110, p. 141-147, 2011

[80] Modibedi, R.M.; Masombuka, T.; Mathe, M.K. Carbon supported Pd-Sn and $\mathrm{Pd}-\mathrm{Ru}-\mathrm{Sn}$ nanocatalysts for ethanol electro-oxidation in alkaline medium. Int. $\boldsymbol{J}$. Hydrogen Energy; v. 36, p. 4664-4672, 2011.

[81] Ren, Y.; Zhang, S.; Li, H. Electro-oxidation of methanol on SnO2-promoted Pd/MWCNTs catalysts in alkaline solution. Int. J. Hydrogen Energy, v.39, p. 288296, 2014

[82] Ramulifho, T.; Ozoemena, K.I.; Modibedi, R.M.; Jafta, C.J.; Mathe, M.K. Electrocatalytic oxidation of ethylene glycol at palladium-bimetallic nanocatalysts (PdSn and PdNi) supported on sulfonate-functionalised multi-walled carbon nanotubes. J. Electroanal Chem. v. 692, p.26-30, 2013. 
[83] Mao, H; Wang, L; Zhu, P; Xu, Q; Li, Q. Carbon-supported PdSn-SnO2 catalyst for ethanol electro-oxidation in alkaline media. Int. J. Hydrogen Energy, v. 39, p. $17583-17588,2014$.

[84] Pawley, G.S. Unit-Cell Refinement from Powder Diffractions Scans. J. Appl. Crystallogr.; v.14, p.357-361, 1981.

[85] Fang, X.; Wang, L.; Shen, P.K.; Cui, G.; Bianchini C. An in situ Fourier transform infrared spectroelectrochemical study on ethanol electrooxidation on $\mathrm{Pd}$ in alkaline solution. J. Power Sources; v. 195, p. 1375-1378, 2010.

[86] Zhu, M.; Sun, G.; Xin, Q. Effect of alloying degree in PtSn catalyst on the catalytic behavior for ethanol electro-oxidation. Electrochim Acta, v. 54, p. 15111518, 2009.

[87] Zhu, M.; Sun, G.; Li, H.; Cao, L.; Xin, Q. Effect of the Sn(II)/Sn(IV) Redox Couple on the Activity of PtSn/C for Ethanol Electro-oxidation. Chin. J. Catal., v. 29, p. 765-770, 2008.

[88] García-Rodríguez, S.; Somodi, F.; Borbáth, I.; Margitfalvi, J.L.; Peña, M.A.; Fierro, J.L.G. et al. Controlled synthesis of Pt-Sn/C fuel cell catalysts with exclusive Sn-Pt interaction: Application in $\mathrm{CO}$ and ethanol electrooxidation reactions. Appl. Catal. B., v. 91, p. 83-91, 2009.

[89] de Oliveira, M.B.; Profeti, L.P.R.; Olivi, P. Electrooxidation of methanol on $\mathrm{PtMyO}_{\mathrm{x}}(\mathrm{M}=\mathrm{Sn}, \mathrm{Mo}$, Os or W) electrodes. Electrochem. Comm.; v.7, p.703-709, 2005.

[90] Jiang, L.; Colmenares, L.; Jusys, Z.; Sun, G.Q.; Behm, R.J. Ethanol electrooxidation on novel carbon supported $\mathrm{Pt} / \mathrm{SnOx} / \mathrm{C}$ catalysts with varied $\mathrm{Pt}: \mathrm{Sn}$ ratio. Electrochim. Acta.; v. 53, p. 377-389, 2007.

[91] Jiang L, Sun G, Sun S, Liu J, Tang S, Li H, et al. Structure and chemical composition of supported Pt-Sn electrocatalysts for ethanol oxidation. Electrochim. Acta.; v. 50, p. 5384-5389, 2005.

[92] Castro, J.C.; Assumpção, M. H. M. T.; de Souza, R. F. B.; Spinacé, E. V.; Neto, A. O.; Electro-Oxidation of Ethanol on $\mathrm{PtSnRh} / \mathrm{C}-\mathrm{Sb}_{2} \mathrm{O}_{5}$ center dot $\mathrm{SnO}_{2}$ Electrocatalysts Prepared by Borohydride Reduction. Electrocatal., v.4, n. 3, p. 159-166.

[93] Wang, N.; Perret, N.; Foster, A. Sustainable hydrogen production for fuell cells by steam reforming of ethylene glycol: A consideration of reaction thermodynamics. Int J. Hydrogen Energy, v.36, p. 5932-5940, 2011. 